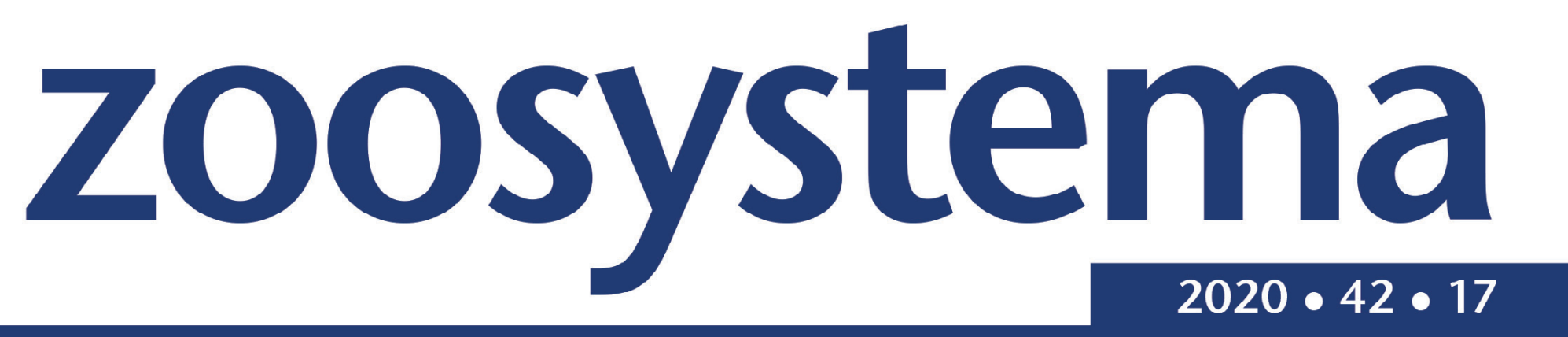

A revision of Carcinoplax abyssicola (Miers, 1885) and seven related species of Carcinoplax H. Milne Edwards, 1852, with the description of two new species and an updated key to the genus (Crustacea, Decapoda, Brachyura, Goneplacidae)

Peter K. L. NG \& Peter CASTRO

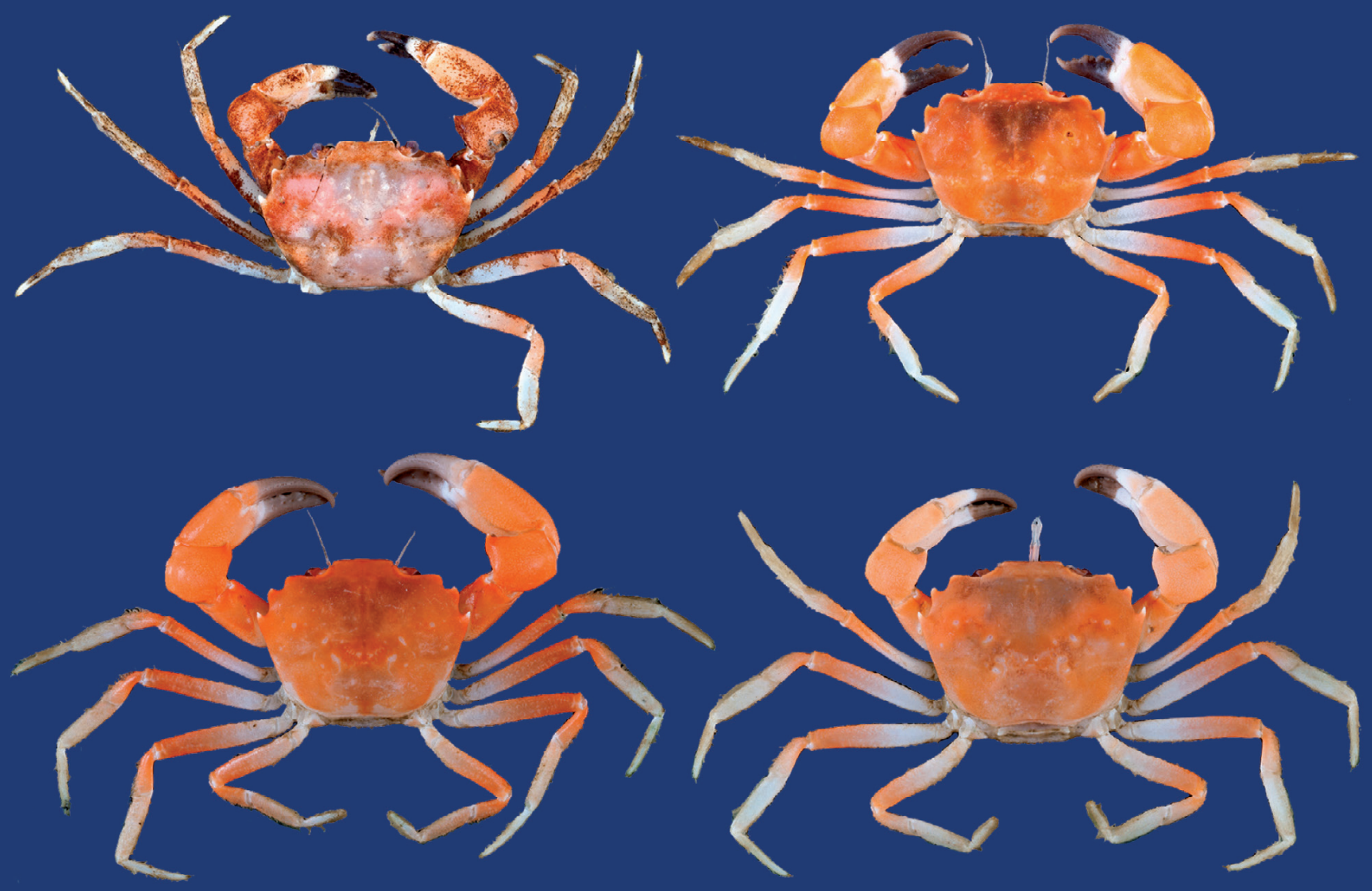


Directeur de LA publication / Publication diRECTOR: Bruno David

Président du Muséum national d'Histoire naturelle

RÉDACTRICE EN CHEF / EDITOR-IN-CHIEF: Laure Desutter-Grandcolas

ASSISTANTE DE RÉDACTION / AsSISTANT EDITOR: Anne Mabille (zoosyst@mnhn.fr)

Mise en PAge / PAge LAYOUt: Anne Mabille

COMITÉ SCIENTIFIQUE / SCIENTIFIC BOARD:

James Carpenter (AMNH, New York, États-Unis)

Maria Marta Cigliano (Museo de La Plata, La Plata, Argentine)

Henrik Enghoff (NHMD, Copenhague, Danemark)

Rafael Marquez (CSIC, Madrid, Espagne)

Peter $\mathrm{Ng}$ (University of Singapore)

Norman I. Platnick (AMNH, New York, États-Unis)

Jean-Yves Rasplus (INRA, Montferrier-sur-Lez, France)

Jean-François Silvain (IRD, Gif-sur-Yvette, France)

Wanda M. Weiner (Polish Academy of Sciences, Cracovie, Pologne)

John Wenzel (The Ohio State University, Columbus, États-Unis)

COUVERTURE / COVER:

Colour in life, Carcinoplax abyssicola (Miers, 1885).

Zoosystema est indexé dans / Zoosystema is indexed in:

- Science Citation Index Expanded (SciSearch ${ }^{\circledR}$ )

- ISI Alerting Services ${ }^{\circledR}$

- Current Contents ${ }^{\circledR}$ / Agriculture, Biology, and Environmental Sciences ${ }^{\circledR}$

- Scopus ${ }^{\circledR}$

Zoosystema est distribué en version électronique par / Zoosystema is distributed electronically by:

- BioOne ${ }^{\circledR}$ (http://www.bioone.org)

Les articles ainsi que les nouveautés nomenclaturales publiés dans Zoosystema sont référencés par / Articles and nomenclatural novelties published in Zoosystema are referenced by:

- ZooBank ${ }^{\circledR}$ (http://zoobank.org)

Zoosystema est une revue en flux continu publiée par les Publications scientifiques du Muséum, Paris / Zoosystema is a fast track journal published by the Museum Science Press, Paris

Les Publications scientifiques du Muséum publient aussi / The Museum Science Press also publish:

Adansonia, Geodiversitas, Anthropozoologica, European Journal of Taxonomy, Naturae, Cryptogamie sous-sections Algologie, Bryologie, Mycologie.

Diffusion - Publications scientifiques Muséum national d'Histoire naturelle

CP $41-57$ rue Cuvier F-75231 Paris cedex 05 (France)

Tél.: 33 (0)1 40794805 / Fax: 33 (0)1 40793840

diff.pub@mnhn.fr / http://sciencepress.mnhn.fr

(C) Publications scientifiques du Muséum national d'Histoire naturelle, Paris, 2020

ISSN (imprimé / print): 1280-9551/ ISSN (électronique / electronic): 1638-9387 


\section{A revision of Carcinoplax abyssicola (Miers, 1885) and seven related species of Carcinoplax H. Milne Edwards, 1852, with the description of two new species and an updated key to the genus (Crustacea, Decapoda, Brachyura, Goneplacidae)}

Peter K. L. NG

Lee Kong Chian Natural History Museum, National University of Singapore, 2 Conservatory Drive, Singapore 117377 (Republic of Singapore)

Peter CASTRO Biological Sciences Department, California State Polytechnic University, Pomona, CA 91768 (United States) pcastro@cpp.edu (corresponding author)

Submitted on 13 August 2019 | Accepted on 12 December 2019 | Published on 9 June 2020

KEY WORDS Goneplacoidea, deep-sea fauna, Pacific region,
new species.
urn:Isid:zoobank.org:pub:52C73176-6867-4415-A6FA-BAD328E9781D

Ng P. K. L. \& Castro P. 2020. - A revision of Carcinoplax abyssicola (Miers, 1885) and seven related species of Carcinoplax H. Milne Edwards, 1852, with the description of two new species and an updated key to the genus (Crustacea, Decapoda, Brachyura, Goneplacidae). Zoosystema 42 (17): 239-284. https://doi.org/10.5252/zoosystema2020v42a17. http://zoosystema.com/42/17

\section{ABSTRACT}

The identities of the deep-water brachyuran crabs Carcinoplax abyssicola (Miers, 1885), C. longipes (Wood-Mason, 1891), and C. specularis Rathbun, 1914 (family Goneplacidae MacLeay, 1838) are clarified on the basis of the examination of types and of an extensive series of specimens from the Indo-West Pacific region, including colour photographs of fresh specimens. Two species described from the Philippines, C. verdensis Rathbun, 1914 and C. polita Guinot, 1989, and previously synonymised under C. specularis, are shown to be distinct species. Two new species, C. adelphia n. sp. and C. jugum n. sp., are described from Vanuatu and the Philippines, respectively. Carcinoplax adelphia n. sp. differs from the closely allied C. specularis by having a male first gonopod (G1) that is relatively more elongated, particularly the distinctly more slender distal half, than the G1 of C. specularis. Carcinoplax jugum n. sp. is characterized by a suite of characters that includes an epistome with strongly concave lateral margins, a carapace having distinctly swollen gastric and cardiac regions, and a G1 with a subconical distal part. The taxonomies of these seven species, as well as that of the allied $C$. fasciata $\mathrm{Ng} \&$ Kumar, 2016 from southwestern India, are revised. A revised, updated key to the 25 known species of Carcinoplax H. Milne Edwards, 1852 is also provided. 


\begin{abstract}
RÉSUMÉ
Révision de Carcinoplax abyssicola (Miers, 1885) et de sept espèces apparentées du genre Carcinoplax H. Milne Edwards, 1852, avec la description de deux nouvelles espèces et une clé mise à jour des espèces du genre (Crustacea, Decapoda, Brachyura, Goneplacidae).

L'identité des crabes brachyoures des eaux profondes Carcinoplax abyssicola (Miers, 1885), C. longipes (Wood-Mason, 1891), et C. specularis Rathbun, 1914 (Goneplacidae MacLeay, 1838) sont clarifiées sur la base de l'examen des types et d'une vaste collection de spécimens provenant de la région indo-pacifique occidentale, ainsi que de photographies de spécimens frais. Deux espèces décrites des Philippines, C. verdensis Rathbun, 1914 et C. polita Guinot, 1989, antérieurement mises en synonymie avec $C$. specularis, sont des espèces distinctes. Deux nouvelles espèces, C. adelphia n. sp. et $C$. jugum n. sp., sont décrites respectivement du Vanuatu et des Philippines. Carcinoplax adelphia n. sp. diffère d'une espèce très proche, $C$. specularis, par son premier pléopode mâle $(\mathrm{G} 1)$ relativement plus allongé, en particulier la moitié distale nettement plus mince, que le G1 de C. specularis. Carcinoplax jugum n. sp. est caractérisé par un ensemble de caractères qui comprend un épisome avec des marges latérales fortement concaves, une carapace dotée de régions gastriques et cardiaques nettement gonflées, et un G1 avec une partie distale subconique. La taxonomie de ces sept espèces et d'une espèce apparentée, C. fasciata $\mathrm{Ng} \&$ Kumar, 2016 du sud-ouest de l'Inde, est revue. Une clé d'indentification révisée et mise à jour des 25 espèces connues du genre Carcinoplax H. Milne Edwards, 1852 est également proposée.
\end{abstract}

\begin{abstract}
faune des grands fonds, région pacifique indooccidentale, espèces nouvelles.
\end{abstract}

MOTS CLÉS

\section{INTRODUCTION}

The goneplacid genus Carcinoplax H. Milne Edwards, 1852 is well represented across the Indo-West Pacific region, with 25 species so far known (Castro 2007, 2009; Ng et al. 2008; Ng \& Kumar 2016; Ng \& Mitra 2019). First studied at length by Guinot (1989), based mainly on the Philippine material from the MUSORSTOM expeditions, the genus underwent a major taxonomic revision by Castro (2007), who redefined Carcinoplax s. str. and established four new genera.

The species of Carcinoplax are characterized by several characters (see Castro 2007): having a transversely rectangular carapace; a lamellar front, straight, rarely marked by a slight median notch or projection; narrow orbits; rounded suborbital borders, each with a blunt inner tooth not visible dorsally; convex anterolateral borders; a tooth typically on outer orbital angle plus two anterolateral teeth on each side of the carapace; short eye peduncles; medially interrupted sutures $4 / 5,5 / 6,6 / 7,7 / 8$; moderately slender cheliped fingers; dorsal margins of P2-P5 unarmed; dactyli slender, smooth. Male pleon with six freely-movable somites plus telson, narrowly or broadly triangular, somites 4-6 gradually decreasing in width from somite 3 (widest somite); telson about as long as wide; somite 3 covering space between P5 coxae, somite 2 slightly narrower than or as narrow as somite 3 so that somites 1,2 leave small, often triangular portion of thoracic sternite 8 visible or somite 2 much narrower than somite 3 leaving a larger portion of thoracic sternite 8 visible; G1 long, slender, only slightly broadened proximally with truncated or pointed, thin tip; G2 slender, slightly longer than or as long as G1, flagellum shorter than proximal part (peduncle), slightly-expanded tip with one or two (rarely three) spinules; penis arising from P5 coxa, with broad, soft proximal expansion. Female pleon with 6 freely-movable, wide somites; telson wider than long, somite 3 covering space between P5 coxae, somite 2 narrower than somite 3 so that somites 1, 2 leave small, often triangular portion of thoracic sternite 8 visible, or somite 2 as wide as somite 3 so that thoracic sternite 8 is not visible; and vulva of mature females greatly expanded, extending from suture $5 / 6$ to suture $6 / 7$, covered by a soft membrane, never by a sternal vulvar cover.

Over the last five years, the authors began to realise that the taxonomy of several species of Carcinoplax needed to be reappraised. One species, C. specularis Rathbun, 1914, was reported by Castro (2007) as having a wide distribution in the Indo-West Pacific. He noted that the characters previously used to separate $C$. specularis from congeners were unclear or proved too variable to be reliable and consequently synonymised two species, C. verdensis Rathbun, 1914 and C. polita Guinot, 1989, with it. He also suggested that the poorly known C. abyssicola (Miers, 1885) was closely related or even synonymous. More collections in the western Pacific and Indian oceans, however, showed that there appeared to be size, morphological, and colour differences between some populations of C. speculariss. str. More recently, $\mathrm{Ng} \&$ Kumar (2016), when comparing their new species, C. fasciata from India with C. specularis s. str., suggested that the western Indian Ocean population belonged to their $C$. fasciata instead and that $C$. specularis was a species complex. The taxonomies of C. abyssicola and C. longipes (Wood-Mason, 1891) are also not well known. Carcinoplax abyssicola is known only from the small holotype male from Fiji and has not been reported since, while $C$. longipes was described from India but has also been reported from Philippines (see Guinot 1989; Castro 2007). In comparing C. fasciata with C. longipes, $\mathrm{Ng} \&$ Kumar (2016: 199) commented that the " $C$. longipes as figured in Alcock \& Anderson (1895: pl. 14, fig. 7) in the Investigator plates from the Andamans differs from that shown in Serène $\&$ Lohavanijaya (1973: 65 [part], pl. 14D), Guinot (1989: 303, pl. 10A-C) and Castro (2007: 636) from the Andamans and Philippines 
in having more triangular anterolateral teeth and distinctly shorter ambulatory legs (see Castro 2007: 637). It is possible that the type material is mixed and contains two species."

Part of the confusion in the taxonomy of these species is that C. polita, C. verdensis, and C. specularis, as well as C. jugum n. sp., all occur in the Philippines, with some stations containing specimens of two or even three species. The large series of recently collected specimens from the Philippines has allowed us to have a better understanding of the species concerned and the degree of variation of the various characters used. New characters (e.g. the structure of the posterior margin of the epistome, shape of the male pleon and colour) have also helped. The structure of the male first gonopod, while not always useful in the taxonomy of the species of Carcinoplax, has also proved helpful in separating the taxa as some of the features have proved to be constant when a good series of specimens are examined. Reappraisals of a good series of specimens from the western Pacific, particularly Indonesia, Fiji, and Tonga now also allowed us to clarify the precise identities of $C$. abyssicola and $C$. longipes.

Most of the species treated herein key out to epithet 13 of the key to the species of Carcinoplax by Castro (2007: 626) and epithet 19 of the updated key (see below). These species typically do not exceed $30 \mathrm{~mm}$ in carapace length, have a low outer orbital tooth, two distinct and sharp anterolateral teeth, none of which are ever distinctly curved anteriorly. Only one new species treated can reach carapace lengths of almost $35 \mathrm{~mm}$, C. jugum n. sp., which has been confused with C. specularis s.l. or C. polita (cf. Guinot 1989; Castro 2007). Castro's (2007) epithet 13 also includes $C$. inaequalis (Yokoya, 1933) and C. cracens Castro, 2007, two morphologically very close Indo-West Pacific species. These two taxa, however, can be separated from most of the species we treat herein in having the dorsal surface of the carapace transversed by low ridges and grooves and the outer margin of the carpus of the cheliped with a distinct spine. Only two species treated herein have a similar carapace structure, C. polita and C. jugum n. sp., and only the former has a spine on the outer margin of the carpus of the cheliped (outer surface of carpus unarmed in C. jugum n. sp.). Compared to $C$. inaequalis and $C$. cracens, however, $C$. polita has a granular margin between the anterolateral teeth (Figs 16B; 17A, E) (margin smooth in C. inaequalis and C. cracens; Castro 2007: fig. 3); only about a third of the finger of the cheliped darkly pigmented (Figs $16 \mathrm{~A}, \mathrm{H} ; 17 \mathrm{D}, \mathrm{I}$ ) (more than half of finger pigmented in the two species; Castro 2007: fig. 3), and the legs are proportionately shorter (Figs 16A; 17D) (more prominently elongated in the two species; Castro 2007: fig. 3). A southwestern Pacific (Solomon Islands and New Caledonia) species that superficially resembles some members in epithet 13 in Castro's key (2007) was subsequently described, $C$. uncinata Castro, 2009. This species is excluded from the group of species covered herein by its diagnostic hook-like first anterolateral tooth and by a narrow, J-shaped gap between a prominent outer orbital tooth and the first anterolateral tooth (Castro 2009: fig. 1A). Practically all specimens of $C$. uncinata are also distinguished by a patch of plumose setae on the inner margin of the cheliped propodus. In order to resolve the taxonomy of these species, we consolidated the large collections of specimens that have been identified with C. specularis s.l., C. abyssicola and/or C. longipes, from the Muséum national d'Histoire naturelle in Paris, and the Lee Kong Chian Natural History Museum at the National University of Singapore.

\section{MATERIAL AND METHODS}

\section{ABBREVIATIONS}

Institutions

DABFUK Department of Aquatic Biology \& Fisheries, University of Kerala, Thiruvananthapuram;

MNHN Muséum national d'Histoire naturelle, Paris;

MZB Muzium Zoologicum Bogoriense, Bogor;

NSMT National Museum of Science \& Technology, Tokyo;

NHM The Natural History Museum, London;

USNM United States National Museum of Natural History, Smithsonian Institution, Washington D.C.;

ZMA Zöologisch Museum, Universiteit van Amsterdam, Amsterdam (at present part of The Naturalis Biodiversity Museum, Leiden);

ZRC Zoological Reference Collection, Lee Kong Chian Natural History Museum, National University of Singapore.

\section{Measurements}

Measurements (in millimetres) are of the maximum carapace length (cl) and width (including teeth) (cw), respectively. The original type material examined was re-measured using the same method used in the rest of the more recent material. The terminology used follows Davie et al. (2015).

$\mathrm{cl}$

CW carapace width (including teeth);

G1 male first gonopod;

G2 male second gonopod;

P1 pereiopod 1 (cheliped);

P2-P5 pereiopods 2-5 (ambulatory legs 1-4).

\section{Nomenclature}

The nomenclature used here for Miers' taxa follows Froglia \& Clark (2011), who argue that some of the taxa supposedly published by Miers (1886) were actually made available a year earlier. The authorships and year of publication of the Investigator taxa similarly follow Huys et al. (2014).

\section{CHARACTERS USED}

We have used several new characters as well as re-interpreted some earlier ones. In describing $C$. specularis s. str., Rathbun (1914: 144) observed that "On the upper surface of the manus there is an elongate-oval area which is nearly smooth and shining; viewed with a lens, it shows scattered granules, but presents an altogether different appearance from the rest of the manus, which is covered with crowded granules." This was probably the basis for her name for this species, "specularis" Latin for "transparent surface”). Guinot (1989: 296) described this feature as "une plage oblongue, plus lisse, bien délimitée, très caractéristique et présente sur les deux chélipèdes." This feature is here referred to as a "window", which appears to be an area of the cuticle which is weakly chitinised and/or calcified, although the surface feels as hard and firm as the rest 
of the chela (Fig. 10F). It has been observed only in males. "Windows" can also be observed on another species, C. adelphia n. sp. (e.g. Fig. 19F) and is sometimes present on the median part of the chela in C. abyssicola (e.g. Figs $2 \mathrm{H}$; 3I). It is quite obvious in adults of $C$. specularis and $C$. adelphia n. sp. but not in smaller specimens. The situation for $C$. abyssicola is of interest because the "window" is less distinct than the other two species and is sometimes not obvious even in larger male specimens. In fact, the "window" appears to be more visible with increased periods of preservation in C. abyssicola. Material of C. abyssicola collected in Java in March-April 2018 did not show any hints of the "window" when first collected and photographed when fresh. A trace of the "windows" was actually observed, although with some difficulty when the preserved specimens were first studied in June 2019 (e.g. Fig. 3I). The "window" is paradoxically more visible when photographed than when observed under a binocular. The purpose and significance of the "window" is not known. Such a feature has also been reported for other deep-water crabs, notably on the lower part of the chela of adult males of the portunoid Benthochascon hemingi Alcock \& Anderson, 1899 (Geryonidae Colosi, 1923, Benthochasconinae Spiridonov, Neretina \& Schepetov, 2014), with Ng (2000: 310) calling it a tympanum-like structure.

One reliable character used is the form of the dorsal surface of the carapace. Most species of Carcinoplax have a carapace with a dorsal surface that is more or less evenly convex, with the median gastrocardiac regions gently depressed (e.g. Fig. 14B). In a few species, however, the epibranchial and mesogastric regions are swollen, forming a low but distinct broad transverse ridge on the carapace surface. Posterior to this epibranchialmesogastric ridge, the metagastric and urogastric regions are prominently depressed, which is followed by another broad transverse ridge formed by the swollen mesobranchial and cardiac regions. This gives the dorsal carapace surface a distinctly corrugated appearance (e.g. Figs 16B; 17A, E; 21B; 22B, E), a feature first noted by Guinot (1989: 298) when she described $C$. polita. This character is most easily seen when the carapace surface is dried and the light is directed obliquely at it, and is obvious even in subadults and females. The two species discussed in the present study that possess this character are C. polita and C. jugum n. sp. Two other species, C. inaequalis (Yokoya, 1933) and C. cracens Castro, 2007, also show this character.

The posterior margin of the epistome is a very useful character that has not been used previously but is effective in separating various groups of species. The most distinct form is the one in C. fasciata and C. jugum n. sp., in which the median part is projected ventrally as a prominent triangular structure with the lateral margins prominently concave (e.g. Figs 18D; 21D; 22D). In species like $C$. abyssicola, C. longipes, and $C$. verdensis, the median part is low, truncated and not projected ventrally, and is separated from the gently sinuous to almost straight lateral margins by a distinct notch (e.g. Figs 3D; 4D; 7D; 13D; 14D). Species like C. specularis have a more intermediate condition, with the median part gently protruding, subtruncated to subtriangular in shape, but still separated from the almost straight or slightly sinuous lateral margins by a notch (e.g. Figs 10D; 11D).

The form of the chela is not a reliable species character. Guinot (1989: 307) used it when she commented that " $L a$ différence la plus notable concerne les pinces, courtes et globuleuses chez C. verdensis, ce qui n'est pas le cas chez C. abyssicola." The large series of specimens of these two species we examined show that this character is too variable to be useful. The chelae of $C$. verdensis in particular, vary from relatively slender and appearing more elongated to being stouter, which appears to be the normal male condition (e.g. Figs 3I; 14H). The pigmentation on the cheliped fingers is always present and varies in colour from pale brown to almost black. It has proved to be very useful to separate some of the groups (see discussion for $C$. abyssicola, C. longipes, and C. verdensis). The pigmentation is only along the distal third or at most half of the finger in C. polita and C. jugum n. sp., although it may extend a bit further back along the cutting edges (e.g. Figs 16H; 17I; 21I; 22I). In older and longer-preserved specimens (e.g. in the holotype of C. specularis, Fig. 10A, H; specimens of $C$. longipes from Travancore, India; Figs 6G; $7 \mathrm{I})$, the pigmentation becomes faint and not easily seen but can still be discerned when dried and viewed under the right lighting conditions.

It is noteworthy that all the species treated here are heterochelous, with adults having one larger chela, even for females. On the major chela, there is always a well-developed tooth at the base of the dactylar finger, which is slightly elongated and gently curved posteriorly (e.g. Figs 4H; 5H). Ng \& Tan (1984, 1985) called this the "cutting tooth" and suggested it is used to break gastropod shells open. The minor chela tends to be more slender, with more elongated fingers. For this tooth to be most effective, $\mathrm{Ng} \&$ Tan (1985) suggested that it should be on the right chela as most marine gastropods are dextrally coiled. The major chela is the right one in most of the adult specimens of the species studied here. There are, however, several specimens where the major chela is on the left side, suggesting that this adaptation may not be so developed in the genus. In some species, notably $C$. polita and $C$. jugum n. sp., the basal tooth is relatively short and more molariform in form (e.g. Figs 16H; 17I; 21I; 22I), suggesting it may be used instead to simply crush gastropod or bivalve shells.

The structure of the cheliped carpus has proved to be useful to separate species into groups. Guinot (1989: 298) distinguished $C$. polita from congeners on the presence of a tooth (often acute) on the outer proximal margin of the carpus, but Castro (2007) disagreed because he did not recognize this species as distinct from $C$. specularis s.l. The large series of specimens at hand now show the validity of this character. Only one species, $C$. polita, always possesses a tooth on the outer margin of the carpus, even as juveniles (e.g. Figs 16E, $\mathrm{F} ; 17 \mathrm{D} ; 27 \mathrm{H})$. Even in cases when the tooth is not obvious, a careful examination will always show that it had broken off. The tooth on the inner distal margin of the carpus is also a useful, albeit not always a reliable character, notably for $C$. verdensis. It can be distinguished from the closely related $C$. abyssicola and C. longipes in that the spine is often elongated and the 
distal half sharply tapers to an acute spine in both sexes and even juveniles (e.g. Fig. 14F).

The use of the proportion of the legs (P2-P5) has proven useful to separate some taxa. When specimens of similar size and of the same sex of $C$. abyssicola are compared with those of $C$. longipes (and $C$. verdensis), the relatively shorter legs (notably the meri) are apparent (e.g. Fig. 4A vs Fig. 8A). There is of course some degree of variation in the legs (see discussion for $C$. verdensis) but the large series of specimens of the species examined show that this is a reliable character.

The transverse proportions of the male pleon can be used to separate groups; for example, the pleon of C. absyssicola and C. verdensis are always proportionately wider (Figs $3 \mathrm{H} ; 14 \mathrm{G}$ ) than that of C. specularis (Fig. 10G), notably in the widths of somites 5 and 6 . Again, there is variation in the proportions of the various somites among the species of Carcinoplax, often associated with size (see discussion in $\mathrm{Ng} \&$ Mitra 2019). As such, it is not always a reliable character.

The structure of the G1 has proved to be more useful than previously believed and has been used here to differentiate several species effectively. The G1 was used more recently by $\mathrm{Ng} \&$ Kumar (2016) and Ng \& Mitra (2019) to separate some morphologically very similar species of Carcinoplax. Even when the structures are very similar (e.g. between $C$. abyssicola and C. longipes, and C. specularis and C. adelphia n. sp.), there are sufficient differences in the proximal and distal structures to separate them (Fig. 23A-C, I, E-G, J, K; 25A-D, F-H). This confidence is mainly because there is a good series of specimens at hand, allowing us to better define variations as well as changes associated with size and growth.

\section{SYSTEMATICS}

Family GONEPLACIDAE MacLeay, 1838 Genus Carcinoplax H. Milne Edwards, 1852

Carcinoplax abyssicola (Miers, 1885)

(Figs 1A-D; 2A-H; 3A-I; 4A-H; 5A-H; 23A-D, E-H; 26A-F)

Pseudorhombila (Pilumnoplax) abyssicola Miers, 1885: 588 [Fiji].

Pilumnoplax abyssicola Miers, 1886: xxiv, xl, xlviii, 226, 227 [in list], 228, pl. 19, figs 2, 2a, 2b [Fiji]. — Tesch 1918: 155 [in list], 156 [in key], 156 [Indonesia]. — Serène 1968: 90 [in list]. — Guinot 1969: 526; 1971: 1081 [in list]. — Serène \& Lohavanijaya 1973: 62 [in list], 65 [in key].

Not Pilumnoplax abyssicola - Whitelegge 1900: 158 (= Pycnoplax meridionalis (Rathbun, 1923)).

Neopilumnoplax abyssicola - Serène 1968: 90 [in list].

Carcinoplax abyssicola - Guinot 1969: 526; 1989: 305, fig. 38; pl. 9 , figs A-C [holotype] [Fiji]. — Castro 2007: 623 [in list]. 627 [in key], 628 [holotype] [Fiji]. — Ng et al. 2008: 80 [in list].

Carcinoplax specularis [part] - Castro 2007: 640 [Indonesia, New Guinea, Solomon Islands, Vanuatu, New Caledonia, Fiji, Tonga].
Type Material. - Holotype. Fiji. ơ', $8.2 \times 10.0$ mm (Castro 2007), Challenger; stn 173; NHM 84.31.

Type locality. - Fiji, Challenger; stn 173; 576 m depth.

MATERIAL EXAMINED. - Indonesia • 1 \% $11.2 \times 15.2 \mathrm{~mm}$; Kai Is.; KARUBAR; stn CP59; 08²0'S, $132^{\circ} 11^{\prime} \mathrm{E}$; 399-405 m depth; 31.X.1991; MNHN-IU-2016-100 (= MNHN-B29387) • 1 ㅇ, 19.3 $\times 24.5 \mathrm{~mm}$; KARUBAR; stn CP63; 08 ${ }^{\circ} 00^{\prime} \mathrm{S}, 132^{\circ} 58^{\prime} \mathrm{E} ; 214-215 \mathrm{~m}$ depth; 1.XI.1991; MNHN-IU-2016-99 (= MNHN-B29380) - 1 o, $12.4 \times 17.6$ mm; Java; E. Sunda Strait; SJADES; stn CP7; 0544.678'S, $104^{\circ} 51.151$ 'E; 379-409 m depth; 25.III.2018; ZRC $2018.1414 \bullet 4$ o , 1 ovigerous \%, $10^{7}$; same data as ZRC 2019.0568 - 1 o , $13.9 \times 19.9 \mathrm{~mm}, 1$ o , $14.8 \times 20.0 \mathrm{~mm}, 1$ o $^{7}, 12.8 \times 19.1 \mathrm{~mm}$, $10^{7}, 13.6 \times 18.4 \mathrm{~mm}$; Java; E. Sunda Strait; SJADES; stn CP8; 05'45.126'S, $104^{\circ} 51.080$ 'E; 425-442 m depth; 25.III.2018; ZRC $2018.1415 \cdot 5$ \% , $7.6 \times 10.1 \mathrm{~mm}$ to $14.5 \times 21.2 \mathrm{~mm}$; same data as ZRC $2019.0569 \bullet 5$ o; same data as ZRC $2019.0569 \bullet 10^{7}, 13.0 \times$ 19.4 mm; SJADES; stn CP10; Java; E. Sunda Strait; 0545.399'S, 104 $56.098^{\prime} \mathrm{E}$; 429-446 m depth; 25.III.2018; ZRC 2018.1416 - 1 o $^{\prime}, 2$ o, $10.0 \times 13.8 \mathrm{~mm}, 11.9 \times 16.1 \mathrm{~mm}, 10^{n}, 13.9 \times 20.3 \mathrm{~mm}$; SJADES; stn CP39; E. Indian Ocean; $08^{\circ} 15.885^{\prime} \mathrm{S}, 109^{\circ} 10.163^{\prime} \mathrm{E}$; 528-637 m depth; 30.III.2018; ZRC 2018.1418.

Papua New Guinea 11 o", $14.3 \times 19.1 \mathrm{~mm}$; BIOPAPUA; stn CP3570; 1.X.2010; $497-500$ m depth; ZRC 2019.1029; ex MNHNIU-2011-1469 • 1 ơn $^{n}, 11.8 \times 16.5 \mathrm{~mm}$; BIOPAPUA; stn CP3740; 556-645 m depth; 10.X.2010; MNHN-IU-2011-2471 • 1 ơ, $13.2 \times$ $16.4 \mathrm{~mm}$; BIOPAPUA; stn CP3742; 448-470 m depth; 10.X.2010; ZRC 2019.1028; ex MNHN-IU-2011-2001・1 \%, $13.9 \times 11.0$ mm; PAPUA NIUGNI; stn CP3970; 04³9'S, $145^{\circ} 52^{\prime} \mathrm{E}$; 573 m depth; 4.12.2012; MNHN-IU-2013-9399 • 1 \%, $11.0 \times 11.7$ mm; PAPUA NIUGNI; stn CP4033; 04²52'S, $145^{\circ} 53^{\prime} \mathrm{E} ; 780 \mathrm{~m}$ depth; 16.12.2012; MNHN-IU-2013-9402 • 1 \% $11.8 \times 16.7$ mm; PAPUA NIUGNI; stn CP4042; 035' S, $144^{\circ} 40$ 'E; 495-693 m depth; 18.XII.2012; MNHN-IU-2013-9391 • $10^{\prime 7}, 8.7 \times 11.0$ mm; PAPUA NIUGNI; stn CP4048; $03^{\circ} 20^{\prime} \mathrm{S}, 143^{\circ} 28^{\prime} \mathrm{E}$; 325-345 m depth; 19.XII.2012; MNHN-IU-2013-9405 $100^{7}, 6.0 \times 7.4 \mathrm{~mm}$; same data as MNHNIU-2013-9405; MNHN-IU-2013-15592 • $1 \mathrm{o}^{\prime \prime}, 8.1 \times 9.9 \mathrm{~mm}$; same data as MNHN-IU-2013-9405; MNHN-IU-2013-9393.

Solomon Islands • 1 \% , $11.7 \times 15.9$ mm; SALOMON 1; stn CP1747; $09^{\circ} 21.8^{\prime} \mathrm{S}, 159^{\circ} 58.7^{\prime} \mathrm{E}$; 364-402 m depth; 25.IX.2001; MNHNIU-2016-129 (= MNHN-B29394) • 1 \%, $11.1 \times 16.1 \mathrm{~mm}$; SALOMON 1; stn CP1748; 09 20.4'S, $159^{\circ} 58.2^{\prime} \mathrm{E} ; 509-522$ m depth; 25.IX.2001; MNHN-IU-2016-128 (= MNHN-B29395) • $10^{\prime \prime}, 5.8$ $\times 7.5 \mathrm{~mm}$; SALOMON 1; stn DW1768; 08²1.4'S, $160^{\circ} 41.8^{\prime} \mathrm{E}$; 194-286 m depth; 28.IX.2001; MNHN-IU-2016-127 (= MNHN$29393) \cdot 2$ o, $6.2 \times 7.6 \mathrm{~mm} ; 12.9 \times 16.5 \mathrm{~mm}$; SALOMON 1 ; stn DW1808; 0945.5'S, $160^{\circ} 52.5^{\prime} \mathrm{E}$; 611-636 m depth; 2.X.2001; MNHN-IU-2016-130 (= MNHN-B29396) 1 o, $12.3 \times 18.8 \mathrm{~mm}$; SALOMON 1; stn DW1851; 10²7.6'S, $162^{\circ} 00^{\prime} \mathrm{E} ; 297-350 \mathrm{~m}$ depth; 6.X.2001; MNHN-IU-2016-131 (= MNHN-B29397) - 1 \%, $10.5 \times 13.7 \mathrm{~mm}$; SALOMON 1; stn CP2288; 08³6.3'S, $157^{\circ} 26.5^{\prime} \mathrm{E}$; $509-520 \mathrm{~m}$ depth; 7.XI.2004; MNHN-IU-2016-133 (= MNHN-B30095). $\cdot 2$ o , $10.9 \times 14.0 \mathrm{~mm} ; 13.8 \times 19.2 \mathrm{~mm}$; SALOMON 2; stn CP2195; 08 $25.5^{\prime}$ S, $159^{\circ} 26.4^{\prime} \mathrm{E} ; 543-593 \mathrm{~m}$ depth; 24.X.2004; MNHN-IU-2016-136 (= MNHN-B30111) - 1 ovigerous $9,13.5 \times 18.8 \mathrm{~mm}$; SALOMON 2; stn 2212;07³7.8'S, 157²1.7'E; 400-475 m depth; 26.X.2004; MNHN-IU-2016-134

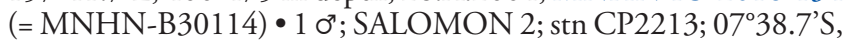
157²2.9'E; 495-650 m depth; 26.X.2004; MNHN-IU-2016-138 (= MNHN-B30097) • 1 \%, 2 O'; SALOMON 2; stn CP2246; 07²42.6'S, 156 24.6'E; 664-682 m depth; 1.X.2004; MNHN-IU-2016-132 $\left(=\right.$ MNHN-B30109) $\bullet 10^{7}, 10.8 \times 14.9 \mathrm{~mm} ;$ SALOMON $2 ;$ stn CP2262; 0756.4'S, $156^{\circ} 51.2^{\prime} \mathrm{E}$; 460-487 m depth; 3.X.2004; MNHN-IU-2016-137 (= MNHN-B30112) 1 juvenile, $6.7 \times$ $8.3 \mathrm{~mm}$; SALOMON 2; stn CP2287; 08 40.8'S, $157^{\circ} 24.6^{\prime} \mathrm{E}$; 253-255 m depth; 6.XI.2004; MNHN-IU-2016-135 (= MNHNB30089) • 1 \%, cl $13.4 \mathrm{~mm}$; carapace damaged; Malaita; SALOMON 
BOA 3; stn CP2787; 08³1'S, 160³9'E; NW 570-885 m depth; 14.IX.2007; MNHN-IU-2010-5567 • $10^{7}, 8.3 \times 9.9 \mathrm{~mm}$; same data as MNHN-IU-2010-5567; MNHN-IU-2010-5568.

Vanuatu • 1 o, $11.9 \times 16.2 \mathrm{~mm}, 2 \mathrm{o}^{7}, 9.9 \times 14.1 \mathrm{~mm}, 14.5 \times$ $19.8 \mathrm{~mm}$; BOA0; stn CP2304; 16³5'S, 16759'E, 564-582 m depth; 14.XI.2004; MNHN-IU-2016-118 • 1 ovigerous $\$$, 12.8 $\times 17.5 \mathrm{~mm}$; BOA0; stn CP2313; $15^{\circ} 04^{\prime} \mathrm{S}, 166^{\circ} 55^{\circ} \mathrm{E}$; 421-482 m depth; 16.XI.2004; MNHN-IU-2016-116) • $10^{\circ}, 10.7 \times 14.0 \mathrm{~mm}$; BOA0; stn CP2330; 295-890 m depth; 18.II.2004; MNHNIU-2016-117) • 1 o , $11.9 \times 14.8 \mathrm{~mm}$; BOA1; stn CP2457, $16^{\circ} 16^{\prime} \mathrm{S}$, $167^{\circ} 19^{\prime} \mathrm{E}$; 630-690 m depth; 6.XII.2005; MNHN-IU-2016-115 - 2 ㅇ, $9.7 \times 12.9 \mathrm{~mm}, 10.4 \times 14.6 \mathrm{~mm}$; SANTO 2006; stn AT9; W. Malo I.; $15^{\circ} 41.5^{\prime}$ S, $167^{\circ} 01.3^{\prime} \mathrm{E}, 481 \mathrm{~m}$ depth; 17.IX.2006; ZRC $2008.0970 \bullet 10^{7}, 8.0 \times 10.6 \mathrm{~mm}$; SANTO 2006; stn AT19; W Malo I.; $15^{\circ} 41^{\prime} S, 167^{\circ} 01^{\prime} \mathrm{E}$; 503-600 m depth; 21.IX.2006; ZRC 2018.1419 • 1 juvenile female; no data; ZRC 2009.0994.

New Caledonia. $30^{\top}$; SMIB 6; stn DW212; 1905.6'S, $163^{\circ} 30.2^{\prime} \mathrm{E}$; 220-225 m depth; 2.III.1990; MNHN-IU-2016-120 (= MNHNB29818) • 1 ơ $^{\prime \prime}, 13.0 \times 17.6 \mathrm{~mm}$; BATHUS 4; stn CP910; $18^{\circ} 59.32^{\prime} \mathrm{S}$, 16308.47’E; 560-608 m depth; 5.VIII.1994; MNHN-IU-2016-111 $\left(=\right.$ MNHN-B29417) $\bullet 20^{\prime \prime} ;$ BATHUS 4; stn CP911; 1857.80'S, $163^{\circ} 08.47^{\prime} \mathrm{E}$; 566-558 m depth; 5.VIII.1994; MNHN-IU-2016-112 (= MNHN-B29420) $110^{7}, 6.0 \times 7.3$ mm; EXBODI: stn CP3788; $22^{\circ} 13^{\prime} \mathrm{S}, 167^{\circ} 07^{\prime} \mathrm{E}$; 264-273 m depth; 3.IX.2011; MNHNIU-2011-8816.

Fiji • 3 ㅇ, largest $11.2 \times 15.6$ mm; MUSORSTOM 10; stn DW1330; $17^{\circ} 09.5^{\prime} \mathrm{S}, 177^{\circ} 56.3^{\prime} \mathrm{E}$; 567-699 m depth; 8.VIII.1998; MNHNIU-2014-11513 (= MNHN-B29504) •3 o , $10^{*}, 10.5 \times 15.3 \mathrm{~mm}$ BORDAU 1; stn DW1393; 16²5'S, 17959'E; 426-487 m depth; 23.II.1999; MNHN-IU-2014-11531 (= MNHN-B29505) 1 juvenile o , 7 o , largest $11.7 \times 16.0 \mathrm{~mm}, 2 \mathrm{o}^{\prime \prime}$, larger one $11.0 \times 15.5 \mathrm{~mm}$; BORDAU 1; stn DW1395; 1645'S, 17959'E; 423-500 m depth; 23.II.1999; MNHN-IU-2014-11529 (= MNHN-B29505) • 1 \% $20^{7}$; ZRC 2019.1030; same data as MNHN-IU-2014-11529 1 0 $0^{7}$, cl $13.4 \mathrm{~mm}$, carapace damaged; BORDAU 1 ; stn CP1401; $16^{\circ} 35^{\prime} \mathrm{S}$, 17941'E; 600-648 m depth; 25.II.1999; MNHN-IU-2014-11532 $\left(=\right.$ MNHN-B29506) $\bullet 10^{7}, 13.3 \times 17.8 \mathrm{~mm} ;$ BORDAU $1 ;$ stn CP1407; 1640'S, $179^{\circ} 39^{\prime} \mathrm{E}, 499-527 \mathrm{~m}$ depth; 25.II.1999; MNHNIU-2014-11533 (= MNHN-B29507) • 9 9 , largest $11.1 \times 15.0 \mathrm{~mm}$, $40^{7}$, largest $12.4 \times 17.6 \mathrm{~mm}$; BORDAU 1; stn DW1447; $16^{\circ} 45^{\prime} \mathrm{S}$, 17959'E; 420-513 m depth; 4.III.1999; MNHN-IU-2014-11530 $\left(=\right.$ MNHN-B29503) $\bullet 2$ o, $20^{7} ;$ ZRC 2019.1027; same data as MNHN-IU-2014-11530 • 1 \%; BORDAU 1; stn CP1448; $16^{\circ} 45^{\prime}$ 'S, 17959’E; 410-500 m depth; 4.III.1999; MNHN-IU-2014-11534 (= MNHN-B29508) • 2 ㅇ, 1 ơ; BORDAU 1; stn DW1451; 16²5'S, 17959'E; 400-460 m depth; 4.III.1999; MNHN-IU-2014-11535 (= MNHN-B29509) $\bullet 1$ juvenile o, 1 \% , cl $9.4 \mathrm{~mm}$, carapace damaged; BORDAU 1; stn DW1453; $16^{\circ} 45^{\prime}$ S, 17959'E; 414510 m depth; 4.III.1999; MNHN-IU-2014-11536 (= MNHNB29510) • 1 ㅇ, $7.2 \times 9.9$ mm; BORDAU 1; stn DW1463; $18^{\circ} 10^{\prime} \mathrm{S}$, 17844'W; 300-400 m depth; 6.III.1999; MNHN-IU-2014-7671 (= MNHN-B29511) • $10^{\prime \prime} ;$ BORDAU 1 ; stn DW1491; 1850’S, 178 52'W; 777-787 m depth; 11.III.1999; MNHN-IU-2014-7697 $(=$ MNHN-B29511).

Tonga $\bullet 1$ juvenile o; BORDAU 2 ; stn CP1530; $21^{\circ} 12^{\prime}$ S, $174^{\circ} 58^{\prime} \mathrm{W}$; 802-803 m depth; 3.VI.2000; MNHN-IU-2014-11538 (= MNHNB29555) • 3 \%; BORDAU 2; stn CP1539; $21^{\circ} 37^{\prime} \mathrm{S}, 175^{\circ} 19^{\prime} \mathrm{W}$; 558-586 m depth; 4.VI.2000; MNHN-IU-2014-11539 (= MNHNB29558) • 1 ㅇ, 1 ơ ; BORDAU 2; stn DW1553; $20^{\circ} 42^{\prime}$ S, $174^{\circ} 54^{\prime} \mathrm{W}$ 650-676 m depth; 6.VI.2000; MNHN-IU-2014-11544 (= MNHNB29566) • 1 o; BORDAU 2; stn CP1556; $20^{\circ} 11^{\prime} \mathrm{S}, 174^{\circ} 45^{\prime} \mathrm{W}$; 589-591 m depth; 7.VI.2000; MNHN-IU-2014-11541 (= MNHNB29560) 1 juvenile $\%$; BORDAU 2; stn CP1557; 20¹0'S 174²'W; $578 \mathrm{~m}$ depth; 7.VI.2000; MNHN-IU-2014-11543 $\left(=\right.$ MNHN-B29563) $\bullet 8$ ovigerous + , 4 \%, $10^{\top} ;$ BORDAU 2 ; stn CP1568; $21^{\circ} 02^{\prime} S, 175^{\circ} 19^{\prime} \mathrm{W} ; 431 \mathrm{~m}$ depth; 10.VI.2000; MNHN2014-11537 (= MNHN-B29309) • 1 $9,10^{7}$; ZRC 2019.1031; same data as MNHN-2014-11537; 2 ovigerous + , largest $13.3 \times$
$18.0 \mathrm{~mm}, 8$ ovigerous 9 , 5 \% , $20^{7}$; same data as MNHN-201411537; MNHN-2014-11537 (= MNHN-B29309) • 2 ovigerous o; BORDAU 2; stn CP1620; $24^{\circ} 18^{\prime} \mathrm{S}, 176^{\circ} 20^{\prime} \mathrm{W} ; 572 \mathrm{~m}$ depth; 18.VI.2000; MNHN-IU-2014-11540 (= MNHN-B29559) • 1 juvenile o; BORDAU 2; stn CP1641; $21^{\circ} 09^{\prime} \mathrm{S}, 175^{\circ} 22^{\prime} \mathrm{W} ; 395 \mathrm{~m}$ depth; 21.VI.2000; MNHN-IU-2014-11542 (= MNHN-B29561).

\section{RE-DESCRIPTION}

Carapace (Figs 1A, D; 2A, B, I; 3A, B; 4A, B; 5A, B; 26A-F) Quadrate, slightly wider than long $(1.2 \times$ as wide as long in holotype; Castro 2007), anterolateral borders arched; slightly convex, mostly smooth, rarely granular in large specimens, marked by slight transverse elevations in branchial regions. Front (Figs 3C, D; 4C, D; 5C) lamellar, straight, margin not marked by median notch; notch between front, inner edge of supraorbital border. Supraorbital borders sinuous, margins smooth; suborbital borders with short, rounded inner tooth, reduced in some specimens. Outer orbital angles truncated when seen dorsally; first anterolateral teeth rounded but sometimes acute, second curved, acute-tipped. Posterolateral borders arched. Subhepatic, pterygostomial regions, pterygostomial crest, pterygostomial lobe, merus, ischium of third maxilliped endopod with short, small granules. Posterior margin of epistome (Figs 2C; 3C, D; 4C, D; 5C) straight, slight median projection in some specimens; u- or v-shaped notch on each lateral margin.

Chelipeds (Figs 1A, C; 2A, F, H; 3A, F, I; 4A, F, H; 5A, H; $26 A-F$ ) and ambulatory legs (Figs $1 A, D ; 2 A ; 3 A ; 4 A ; 5 A$; 26A-F)

Chelipeds (P1) nearly equal in females and males; fingers slender, about as long or slightly shorter as propodus, with cutting edges, broadly blunt teeth; nearly all distal portion of fingers dark brown in males, half to $3 / 4$ in females (Figs 1A, C; 2A, F, H; 3A, F, I; 4A, H; 5A, H; 26A-F). "Window" (see discussion of $C$. specularis below) observed on outer surface of cheliped propodi in several males (e.g. MNHNIU-2014-11529, $11.0 \times 15.5 \mathrm{~mm}$ [Fig. 3I] and MNHNIU-2016-127, $5.8 \times 7.5 \mathrm{~mm}$ ). Inner, outer (dorsal), distal margin of cheliped carpus with short, triangular to acute tooth (Figs 1A, C; 2F; 3F; 4F; 5E). P2-P5 (Figs 1A, D; 2A; $3 \mathrm{~A} ; 4 \mathrm{~A} ; 5 \mathrm{~A} ; 26 \mathrm{~A}-\mathrm{F}$ ) slender, proportionally long, smooth; many short, simple setae along inner, outer margins of P5 propodus, dactylus, outer margin of P5 carpus; P5 dactylus long, slender, smooth.

Sternum, male pleon (Figs 2D;3H; $4 G$ ), and male gonopods (Fig. 23A-C, E-G)

Tomentum on sternum and pleon of large individuals of both sexes. Male pleon (Figs 2D; 3H; 4G) proportionally wide, with 6 freely-movable somites plus telson; telson slightly wider than long, somite 3 covering space between P5 coxae. Somites 1 , 2 slightly narrower than somite 3 , thoracic sternite 8 not visible. G1 (Fig. 23A-C, E-G) straight, short, obtuse to slightly laterally pointed tip; dorsal surface with numerous minute spinules that nearly reach tip. G2 (Fig. 23D, H) slender, slightly longer than G1, slightly curved flagellum, tip with spinule at each side. 

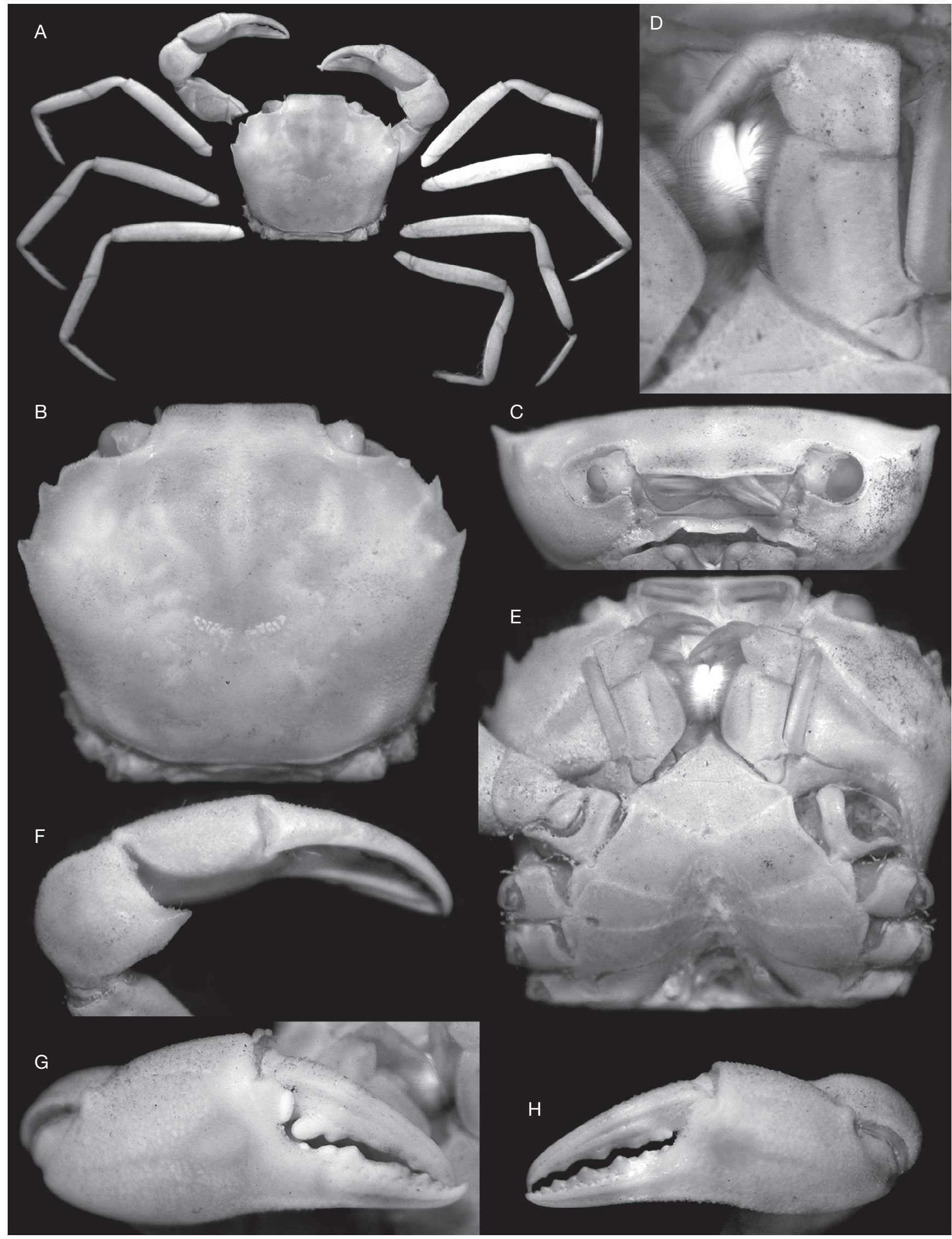

FIG. 1. - Carcinoplax abyssicola (Miers, 1885), holotype ơ $(8.2 \times 10.0 \mathrm{~mm}$ ) (NHM 84.31), Fiji: A, overall habitus; B, dorsal view of carapace; C, frontal view of cephalothorax; D, left third maxilliped; $\mathbf{E}$, thoracic sternum and third maxillipeds; $\mathbf{F}$, dorsal view of left cheliped; $\mathbf{G}$, outer view of right chela; $\mathbf{H}$, outer view of left chela. 
Female pleon (Fig. 5F) and vulva (Fig. 5G)

Female pleon (Fig. 5F) wide; telson slightly wider than long. Somites 1,2 covering space between P5 coxae, thoracic sternite 8 not visible. Vulva of mature females (Fig. 5G) extending from edge of suture $5 / 6$ to suture $6 / 7$; membrane covering aperture leaving space open along pointed anterior margin.

COlOUR IN LIFE. — Carapace and chelipeds light to bright orange; legs white with broad orange band across middle (Fig. 26A-F).

Geographical Distribution. - Indonesia (Kai Is and southern Java), Papua New Guinea, Solomon Islands, Vanuatu, New Caledonia, Fiji, and Tonga.

DEPTH. - Present in samples collected at depths of 194-890 m.

\section{REMARKS}

The taxonomy of $C$. abyssicola, C. longipes, and C. verdensis has been confused mainly because of a shortage of specimens, as well as having type specimens that are small or females. It has been made more difficult because these species sometimes overlap in distribution, with C. abyssicola and C. longipes now known to co-occur in southern Java.

Carcinoplax abyssicola has been a problematic species because it was described from only one small male $(8.2 \times 10.0 \mathrm{~mm}$, NHM 84.31), and its affinities with allied taxa have been far from clear. Guinot (1989) and Castro (2007) examined the holotype male and the present study confirms the specimens from Fiji, Papua New Guinea, Solomon Islands, Vanuatu, New Caledonia, Tonga and Indonesia (Kai Is and southern Java) are conspecific with the type. The anterolateral armature varies to some degree; the holotype has a small first tooth on the right side while that on the left side is missing (Fig. 1B). A male $(10.5 \times 15.3 \mathrm{~mm}$, MNHN-IU-2014-11531) also has an acute right tooth but an obtuse left tooth (Fig. 2I). The holotype specimen no longer has the male pleon and the gonopods are not in the bottle. The G1 and G2 of the holotype, however, were sketched by the second author in 2004. Their morphology agrees with the gonopods drawn here (Fig. 23A-C, E-G), except that the tip of the G1 appears slightly longer. It, however, falls within the variation observed in the species.

The description by Miers (1886: 228) agrees with the material at hand but the diagnostic details in the description are scant. We are therefore re-describing the species in order to include a good number of diagnostic characters not included in the original description. No mention was made of the notch at the lateral borders of the front as well as details on the morphology of the epistome and the gonopods. Miers' figures clearly show the small granules along the anterior portion of the ventral surface of the carapace, which are diagnostic for the species (Miers 1886: pl. 19, fig. 2a; Fig. 1B, C), and the fingers of the male holotype were black along their distal twothirds (Miers 1886: pl. 19, fig. 2b; Fig. 1A, C) (now faded in the type specimen; Fig. 1G, H).

With only one specimen at that time, Guinot (1989) accepted the validity of $C$. abyssicola and indicated that it was close to C. longipes. Castro (2007) commented on the similarities between the holotype of $C$. abyssicola and specimens of C. specularis s.l., a species in which he included two species now being resurrected. He found that the main difference between the two species was the truncated and posteriorly inclined outer orbital angles of the holotype of C. abyssicola, a condition that is visible in the illustrations of the holotype by Guinot (1989: fig. 38; pl. 9, figs A, B).

Although we are now able to separate $C$. specularis s. str. (and the allied C. adelphia n. sp.) from the other species previously included under it (see Remarks for this species), the taxonomic history of C. abyssicola, C. longipes, and C. verdensis is confusing and is best discussed together here.

The presence of a good series of fresh specimens of $C$. $a b$ yssicola and C. longipes in the deep waters of southern Java is significant as it allows us to compare them directly. They are most easily distinguished by the proportions of their legs, which in C. longipes are distinctly longer (Figs 6A; 7A; $8 \mathrm{~A} ; 9 \mathrm{~A} ; 27 \mathrm{~A}-\mathrm{C})$, especially the meri. The ambulatory meri of $C$. abyssicola are relatively shorter and stouter (Figs 1A, E; 2A; 3A; 4A; 5A; 26A-F). Another obvious difference, which can vary occasionally, is the armature of the anterolateral margin (not including the external orbital tooth). The anterolateral teeth of $C$. abyssicola, especially the first one, are more obtusely triangular in adults (Figs 1E; 2B, I; 3B; 4B; 5B). In C. longipes, the teeth are acutely triangular, appearing almost spiniform, and are spaced further apart as a result (Figs 6B; 7B; 8B; 9B). The structure of the posterior margin of the epistome is also useful to separate the two species in most cases; in C. abyssicola, the median truncated lobe is separated from the lateral margins by a relatively shallower and narrower cleft (Figs 2C; 3D; 4F; 5C) but this cleft is deeper and wider in C. longipes (Figs 5C; $6 \mathrm{C} ; 7 \mathrm{D} ; 8 \mathrm{D})$. The structures of their G1 are superficially similar but the general structure is proportionately shorter and more slender, especially on the basal part (Fig. 23A, E) in C. abyssicola, whereas the G1 is more elongated and the basal part is relatively broader and more truncated in C. longipes (Fig. 23I).

The two species differ in their colour in life. Carcinoplax abyssicola is a distinct orange (Fig. 26A-F), with larger specimens dull or dark orange. The legs are white with a broad orange band across middle portions. In contrast, the overall colour in C. longipes is a faded yellowish-orange with the legs more uniformly coloured (Fig. 27A-C).

Carcinoplax abyssicola and C. longipes are both superficially similar to $C$. verdensis in the shape of their carapaces and the relatively more elongated legs, but $C$. verdensis can usually be distinguished by several clear features. The inner distal tooth of the carpus of the cheliped in C. verdensis is usually elongated, with the distal half sharply tapering to an acute spine in both sexes and usually even in subadults (Figs 14F; 15E). The inner distal tooth of the carpal spine is always more obtuse and the distal part is never spiniform in C. abyssicola (Figs 2E; 3G; 4F, 5E) and C. longipes (Figs 6E; 7F; 8F; 9E). The carpal spine of Miers' drawing of the holotype of $C$. abyssicola is nevertheless spiniform (Fig. 1C), but obtuse in Guinot's photograph of the holotype (Fig. 1E). Some specimens of C. verdensis from the Philippine and South China seas, however, have relatively 


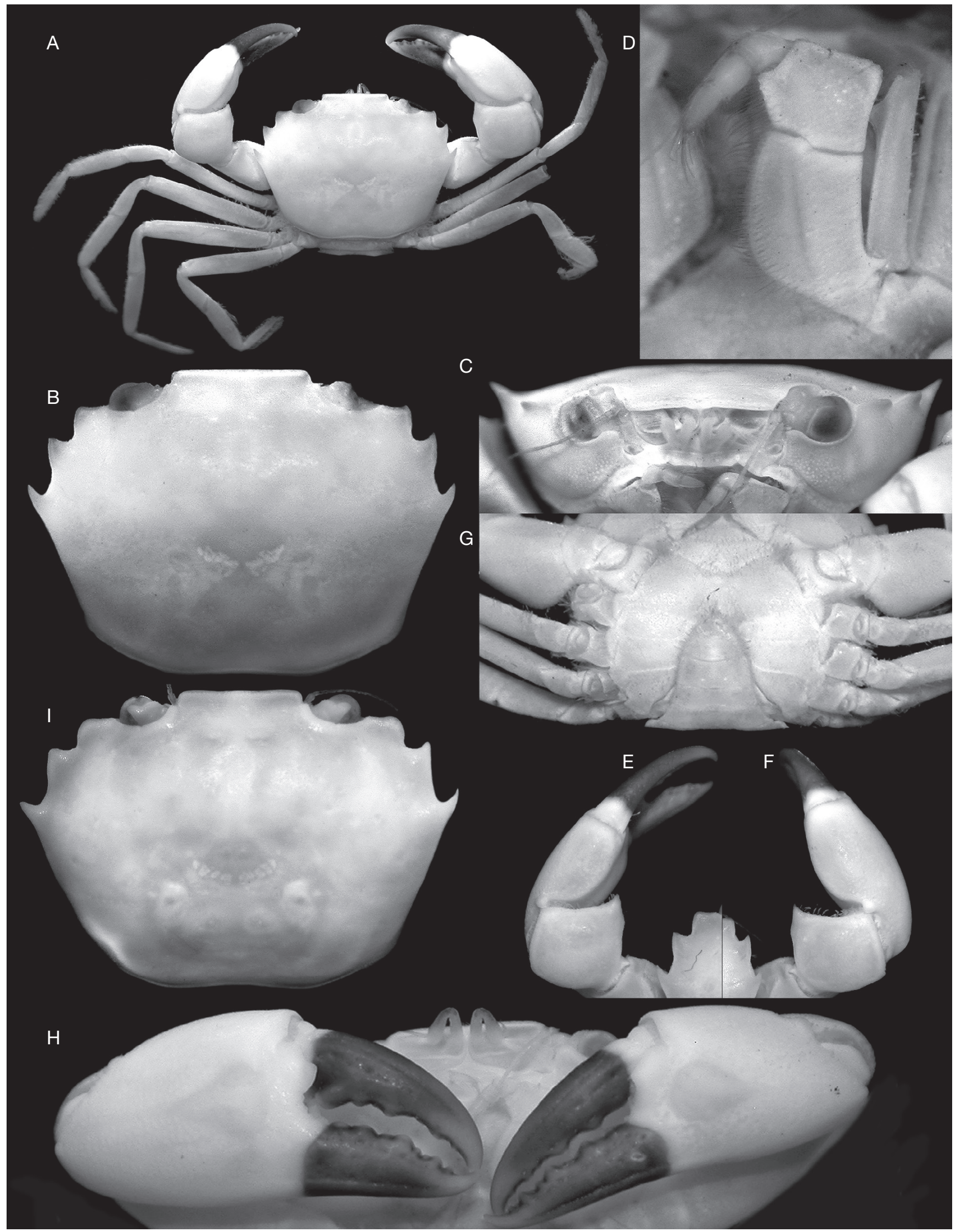

Fig. 2. - Carcinoplax abyssicola (Miers, 1885): A-H, ơ (8.0 × 10.4 mm) (MNHN-IU-2014-11535), Fiji; I, ơ (10.5 × $15.3 \mathrm{~mm}$ ) (MNHN-IU-2014-11531), Fiji; A, overall habitus; B, I, dorsal view of carapace; C, frontal view of cephalothorax; D, left third maxilliped; $\mathbf{E}$, dorsal view of left cheliped; $\mathbf{F}$, dorsal view of right cheliped; $\mathbf{G}$, thoracic sternum and pleon; $\mathbf{H}$, outer view of chelae. 


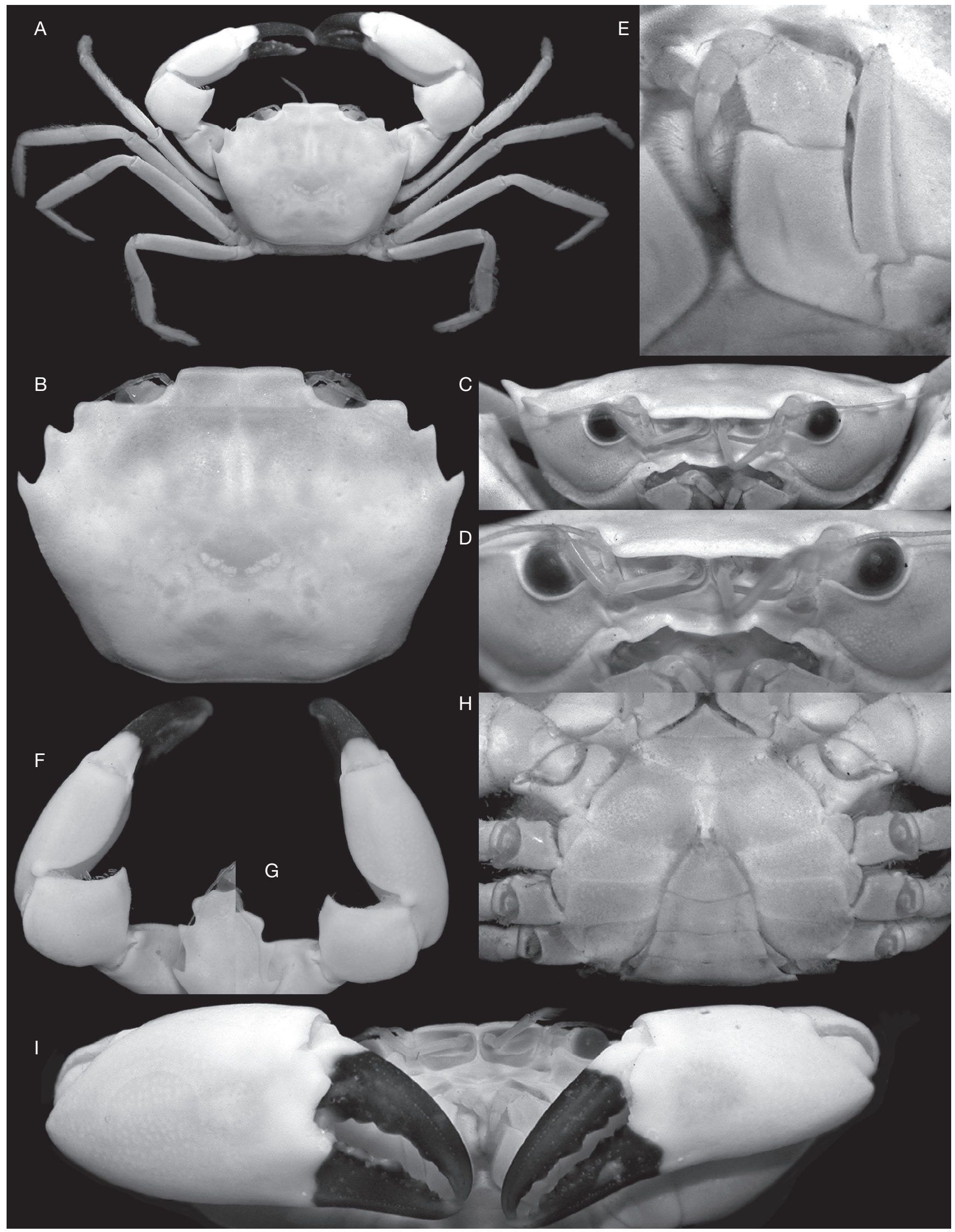

FIG. 3. - Carcinoplax abyssicola (Miers, 1885), ơ (11.0 × $15.5 \mathrm{~mm}$ ) (MNHN-IU-2014-11529), Fiji: A, overall habitus; B, dorsal view of carapace; C, frontal view of cephalothorax; D, posterior margin of epistome; $\mathbf{E}$, left third maxilliped; $\mathbf{F}$, dorsal view of left cheliped; $\mathbf{G}$, dorsal view of right cheliped; $\mathbf{H}$, thoracic sternum and pleon; I, outer view of chelae. 


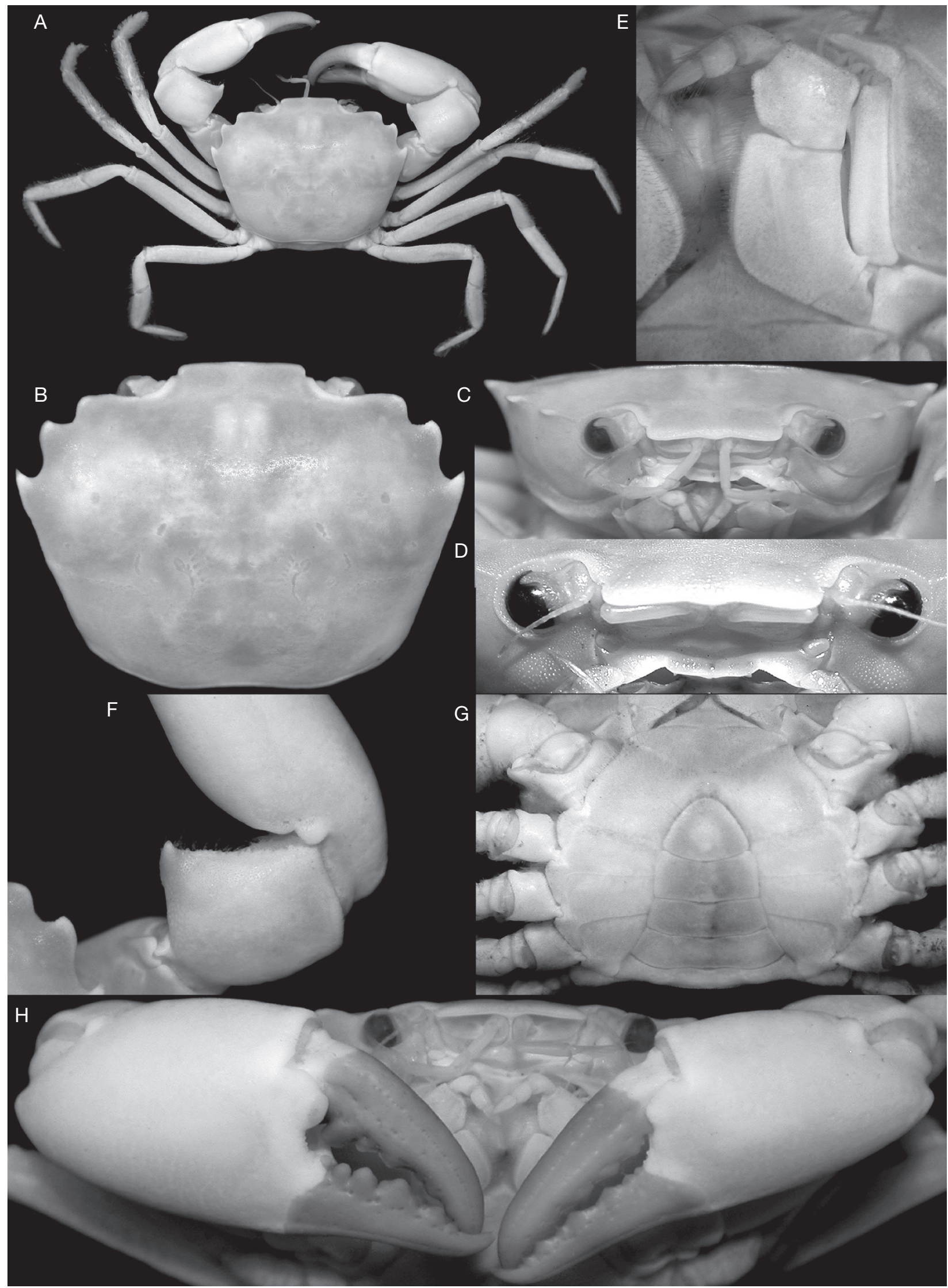

FIG. 4. - Carcinoplax abyssicola (Miers, 1885), o $^{\mathbf{2}}(13.6 \times 18.4 \mathrm{~mm}$ ) (ZRC 2018.1415), Indonesia: A, overall habitus; B, dorsal view of carapace; C, frontal view of cephalothorax; D, posterior margin of epistome; $\mathbf{E}$, left third maxilliped; $\mathbf{F}$, dorsal view of carpus of right cheliped; $\mathbf{G}$, thoracic sternum and pleon; $\mathbf{H}$, outer view of chelae. 


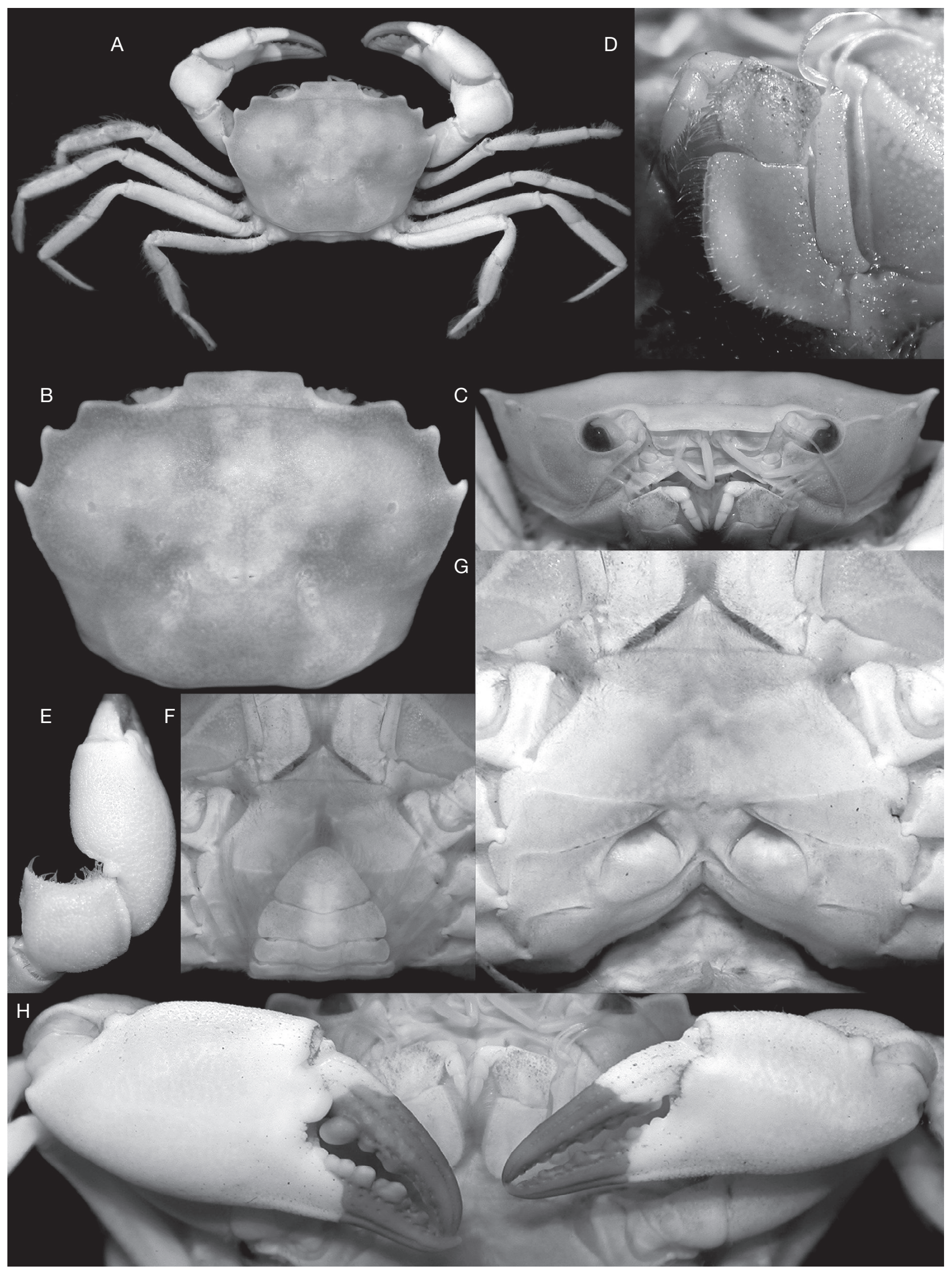

FiG. 5. - Carcinoplax abyssicola (Miers, 1885), $9(14.8 \times 20.0 \mathrm{~mm})$ (ZRC 2018.1415), Indonesia: A, overall habitus; B, dorsal view of carapace; C, frontal view of cephalothorax; D, left third maxilliped; $\mathbf{E}$, dorsal view of carpus of right cheliped; $\mathbf{F}$, thoracic sternum and pleon; $\mathbf{G}$, sternopleonal cavity and vulvae; $\mathbf{H}$, outer view of chelae. 
less elongated carpal spines (Fig. 13F); so this character is not always reliable. The ambulatory meri of $C$. verdensis is usually elongated and slender (Figs 13A; 14A; 15A) like in C. longipes (Figs 6A; 7A; 8A), but the ambulatory merus appears relatively shorter in a few specimens (Fig. 9A), although it is still longer than those of adult $C$. abyssicola (Figs 1A, E; 2A; $3 \mathrm{~A} ; 4 \mathrm{~A} ; 5 \mathrm{~A})$. The structure of the posterior margin of the epistome of $C$. verdensis resembles that of $C$. abyssicola, with the truncated median lobe separated from the lateral margins by a relatively deep cleft (Figs 2C, D; 4D; 5C for C. abyssicola; Figs 6C; 7D; 8D; 9C for C. longipes). Carcinoplax verdensis more closely resembles $C$. longipes in the shape of their anterolateral teeth, with the spines typically more acute and spiniform (Figs 6B; 7B; 8B; 9B for C. longipes; Figs 13B; 14B; 15B for $C$. verdensis). There are, however, several specimens that have more obtuse teeth (Fig. 13B), demonstrating that the shape of anterolateral teeth is not always a reliable character among these and other species of Carcinoplax.

Two characters, however, seem constant for $C$. verdensis and support our view that this is a distinct species. The fingers of the chelipeds in adult $C$. verdensis of both sexes are dark brown or almost black only along the distal two-thirds to half of the fingers (Figs 13I, J; 14H; 15A); whereas in C. abyssicola and $C$. longipes, almost the entire length of the fingers in adults is pigmented (Figs $1 \mathrm{C} ; 2 \mathrm{~F}, \mathrm{H} ; 3 \mathrm{~F}, \mathrm{I} ; 4 \mathrm{H} ; 5 \mathrm{H}$ for $C$. abyssicola; Figs $6 \mathrm{~A} ; 7 \mathrm{~A} ; 8 \mathrm{H}$; $9 \mathrm{H}$ for $C$. longipes). While the $\mathrm{G} 1$ of C. verdensis is similar to that of $C$. abyssicola, being relatively shorter and less broad basally, the distal part in $C$. verdensis is always directed obliquely outwards (Fig. 24A-C), whereas the distal part is more truncated and the tip is directed laterally in C. abyssicola (Fig. 23A-C, E-G).

Additional support on the distinct nature of $C$. abyssicola has been provided by preliminary data based on the barcode region of the cytochrome oxidase I (COI) gene (L. Corbari, unpublished data) as well as $C$. abyssicola and the remaining species treated here (L. M. Tsang, unpublished data).

On the basis of the figures of the specimens, and in particular the structures of the G1, it is clear that the material referred to as 'Carcinoplax aff. longipes' by Guinot (1989) (Fig. 24E, $\mathrm{G})$ belongs to $C$. verdensis as presently defined.

The known geographical distributions of the four species being discussed are relatively distinct. Carcinoplax abyssicola so far is known from the western Pacific, from southeastern Moluccas and southern Java in Indonesia to Tonga (see above) as well as in the easternmost part of the Indian Ocean. Carcinoplax longipes is known only from the Indian Ocean, although it occurs in the same area as $C$. abyssicola in southern Java. The two species, however, seem to have different habitats and were only collected together from one station (out of 10 stations) in Java. Carcinoplax verdensis is known for certain only from Japan, Taiwan, Philippines, and South China Sea (see below). Carcinoplax fasciata is so far known from the Arabian Sea off the coast of Kerala, India. Carcinoplax abyssicola and the species treated here so far extend east as far as Tonga. The only species of Carcinoplax east of Tonga are two small-size species, C. velutina Castro, 2007 and C. uncinata Castro, 2009 both known from French Polynesia. Carcinoplax velutina is also found in Vanuatu, New Caledonia, and Fiji (Castro 2007); C. uncinata in New Caledonia and Solomon Islands (Castro 2009). Carcinoplax uncinata is herein recorded from French Polynesia for the first time (male $8.8 \times 11.4 \mathrm{~mm}$, TARASOC; stn CP3376, Tuamotu Archipelago, 15²1'S, 146 54'W, 646737 m depth; 10.V.2009, MNHN-IU-2011-5233).

The depth distribution is similar in all three species. Specimens of $C$. abyssicola and $C$. longipes were taken at maximum depths of $890 \mathrm{~m}$ and $870 \mathrm{~m}$, respectively, but one specimen of $C$. verdensis was recorded at $2149 \mathrm{~m}$, which is likely to be in error.

Individuals of $C$. abyssicola and $C$. verdensis appear to be larger in size (largest specimens measured reaching $19.3 \mathrm{~mm}$ CL and $19.2 \mathrm{~mm} \mathrm{CL}$, respectively) than those of C. longipes (largest specimen measured $10.8 \mathrm{~mm} \mathrm{CL})$. Of the six species being treated here, $C$. polita is characterised by having the largest measured individuals, with one specimen $25.9 \mathrm{~mm}$ CL.

Specimens collected by the Siboga Expedition from Indonesia and identified as C. abyssicola by Tesch (1918) could not be found in the ZMA, where all other Siboga goneplacids were originally deposited. This record is provisionally recognised as correct as the species is known from that area.

Guinot (1989: 307) commented that in the form of the carapace and anterolateral teeth, $C$. abyssicola was closest to C. verdensis, but differed in having the teeth more spiniform and the chelae being short and globose. While this difference is usually valid for the structure of the anterolateral teeth, the form of the chela varies with size and sex and it is not a reliable character. As discussed earlier, the two species, however, differ in other characters.

\section{Carcinoplax longipes \\ (Wood-Mason in Wood-Mason \& Alcock, 1891) \\ (Figs 6A-G; 7A-I; 8A-H; 9A-H; 23I-L; 27A-C)}

Nectopanope longipes Wood-Mason in Wood-Mason \& Alcock, 1891: 262 [type locality: Andaman Sea].

Nectopanope longipes - Alcock \& Anderson 1895: pl. 14, fig. 7 [Andaman Sea].

Carcinoplax longipes - Alcock 1899: 71; 1900: 302 [in key], 303 [southern India, Andaman Sea]. — Alcock \& Anderson 1899: 5 [in list]. - Doflein 1904: 117, 306 [Andaman Sea]. — Tesch 1918: 154 [in list]. — Serène 1968: 90 [in list]. — Sakai 1969: 270 [in list]. - Serène \& Lohavanijaya 1973: 63, 765, 68, pl. 14, fig. D [Indian material]. - Guinot 1989: 303 [India], fig. 26, pl. 10, figs A-C [Andaman Sea]. — Chen 1998: 266 [in key]. — Ng et al. 2008: 80 [in list]

Carcinoplax longipes [part] - Castro 2007: 636 [Laccadive Sea].

Pilumnoplax longipes - Miers 1886: 226 [in list].

Not Carcinoplax longipes - Sakai 1976: 524 [in key], 527, fig. 281 [Japan] (= C. specularis Rathbun, 1914).

Not Carcinoplax longipes - Miyake 1991: 220 [in list] [Japan]. Takeda et al. 2006: 204 [in list] [Japan]. — Takeda \& Yaganisawa 1985: 61 [in list] [Japan] (?C. specularis Rathbun, 1914 or C. verdensis Rathbun, 1914). 


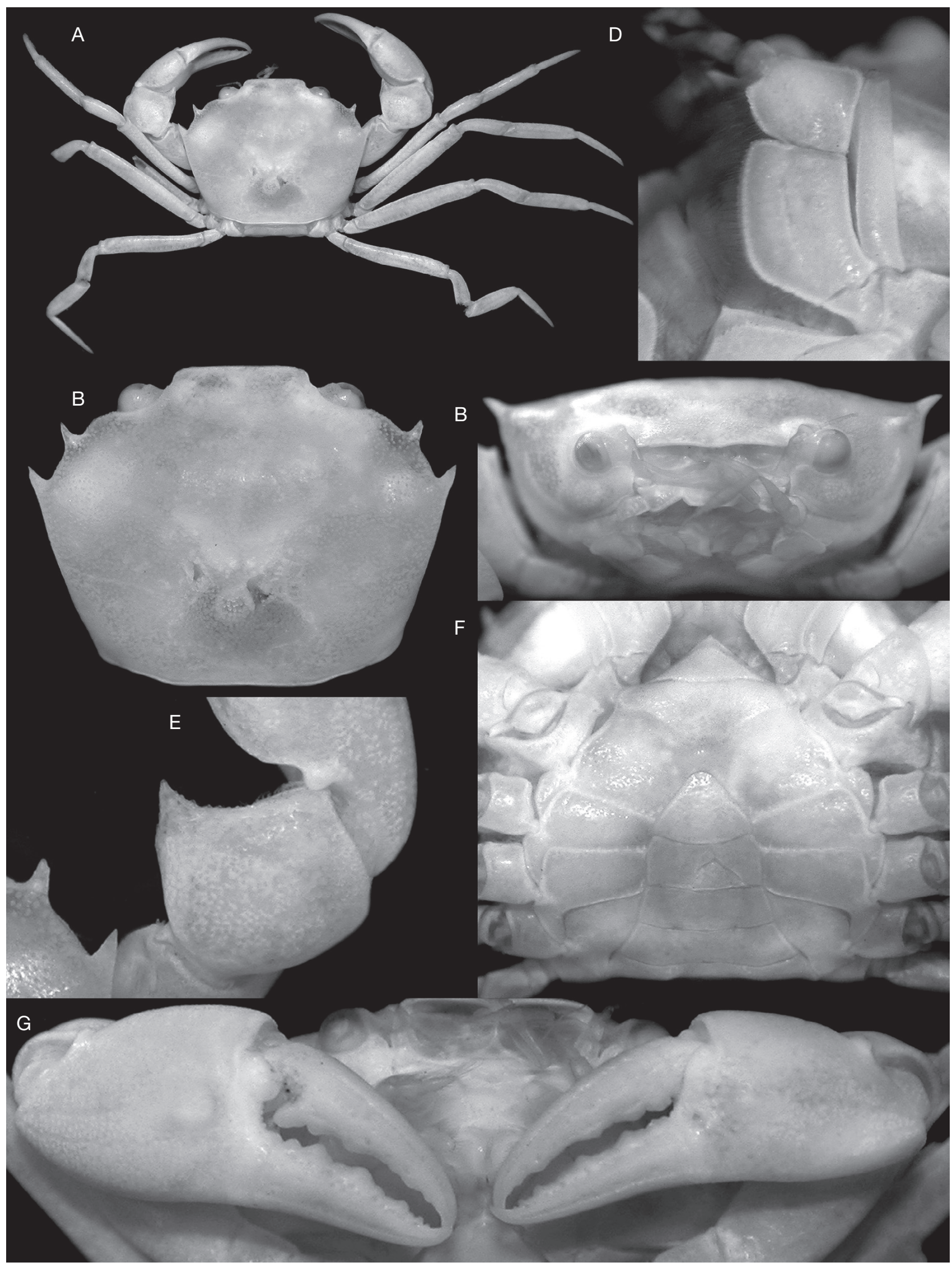

FIG. 6. - Carcinoplax longipes (Wood-Mason, 1891), ơ $(8.5 \times 11.4 \mathrm{~mm}$ ) (USNM 46291), India: A, overall habitus; B, dorsal view of carapace; C, frontal view of cephalothorax; D, left third maxilliped; E, dorsal view of carpus of right cheliped; F, thoracic sternum and pleon; $\mathbf{G}$, outer view of chelae. 


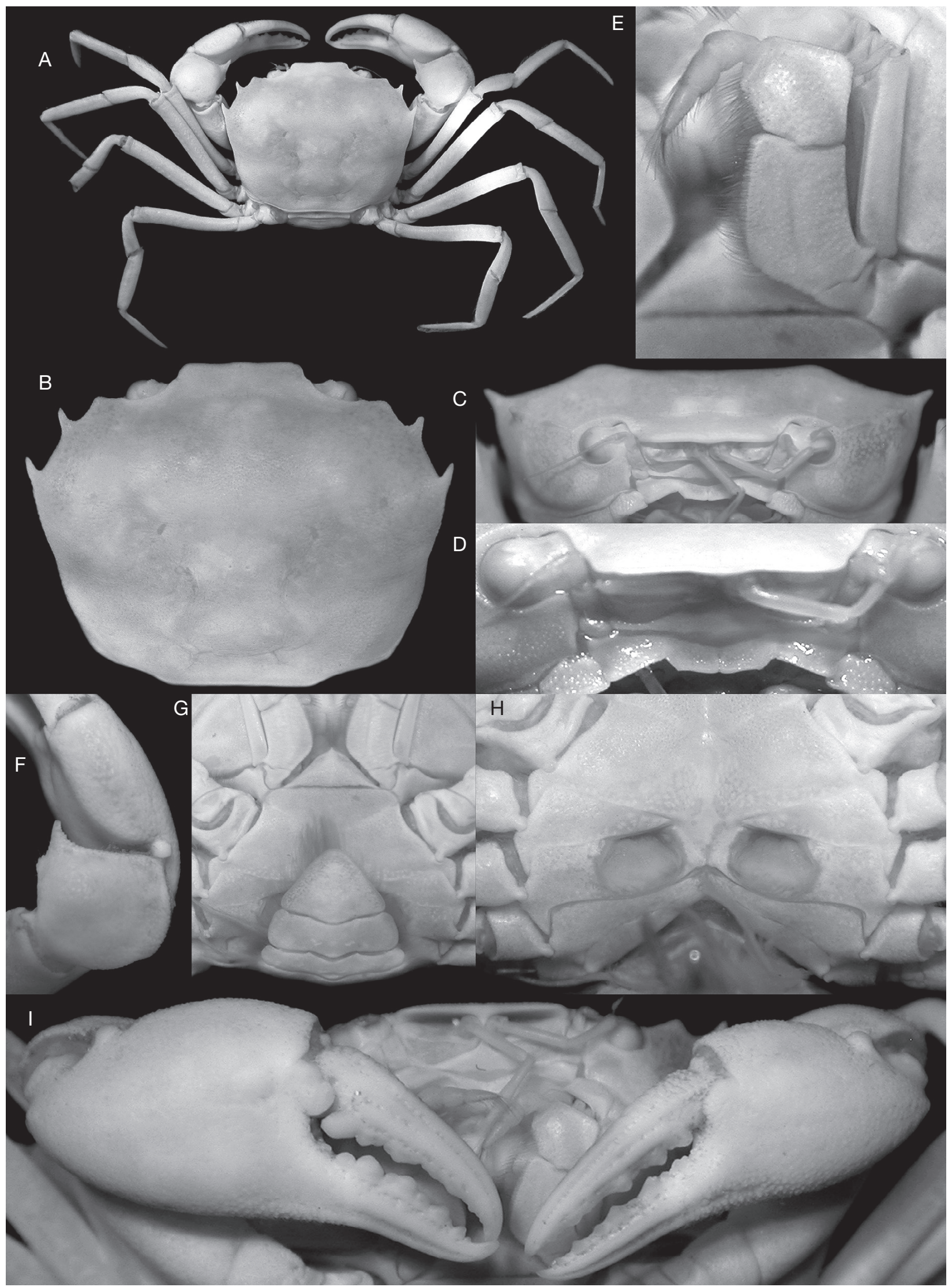

FiG. 7. - Carcinoplax longipes (Wood-Mason, 1891), o $(11.9 \times 15.1 \mathrm{~mm})($ USNM 46291), India: A, overall habitus; B, dorsal view of carapace; C, frontal view of cephalothorax; D, posterior margin of epistome; $\mathbf{E}$, left third maxilliped; $\mathbf{F}$, dorsal view of carpus of right cheliped; $\mathbf{G}$, thoracic sternum and pleon; $\mathbf{H}$, sternopleonal cavity and vulvae; $\mathbf{I}$, outer view of chelae. 


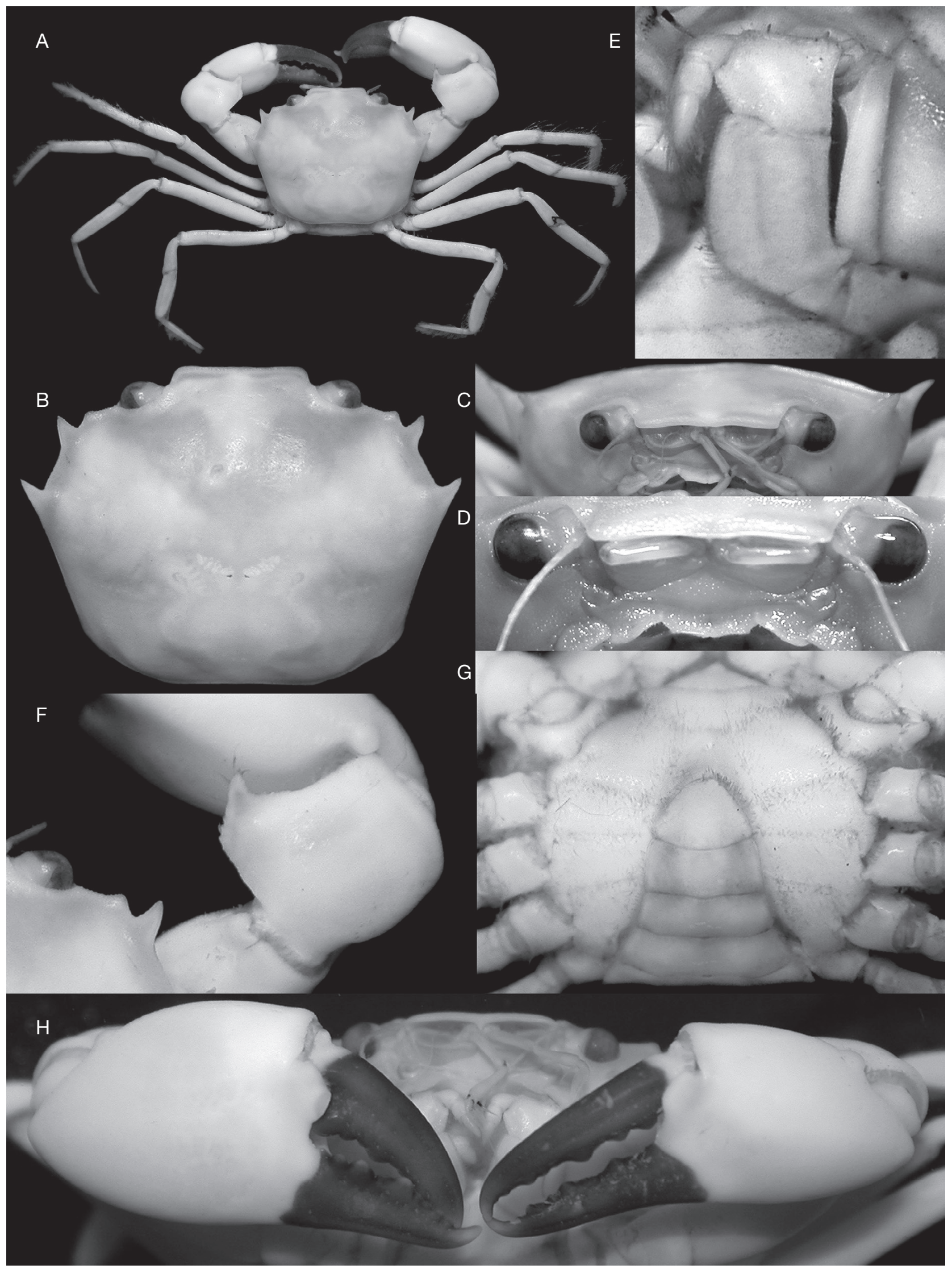

FIG. 8. - Carcinoplax longipes (Wood-Mason, 1891) ơ (9.9 × $13.9 \mathrm{~mm})$ (ZRC 2018.1424), Indonesia: A, overall habitus; B, dorsal view of carapace; C, frontal view of cephalothorax; D, posterior margin of epistome; $\mathbf{E}$, left third maxilliped; $\mathbf{F}$, dorsal view of carpus of right cheliped; $\mathbf{G}$, thoracic sternum and pleon; $\mathbf{H}$, outer view of chelae. 


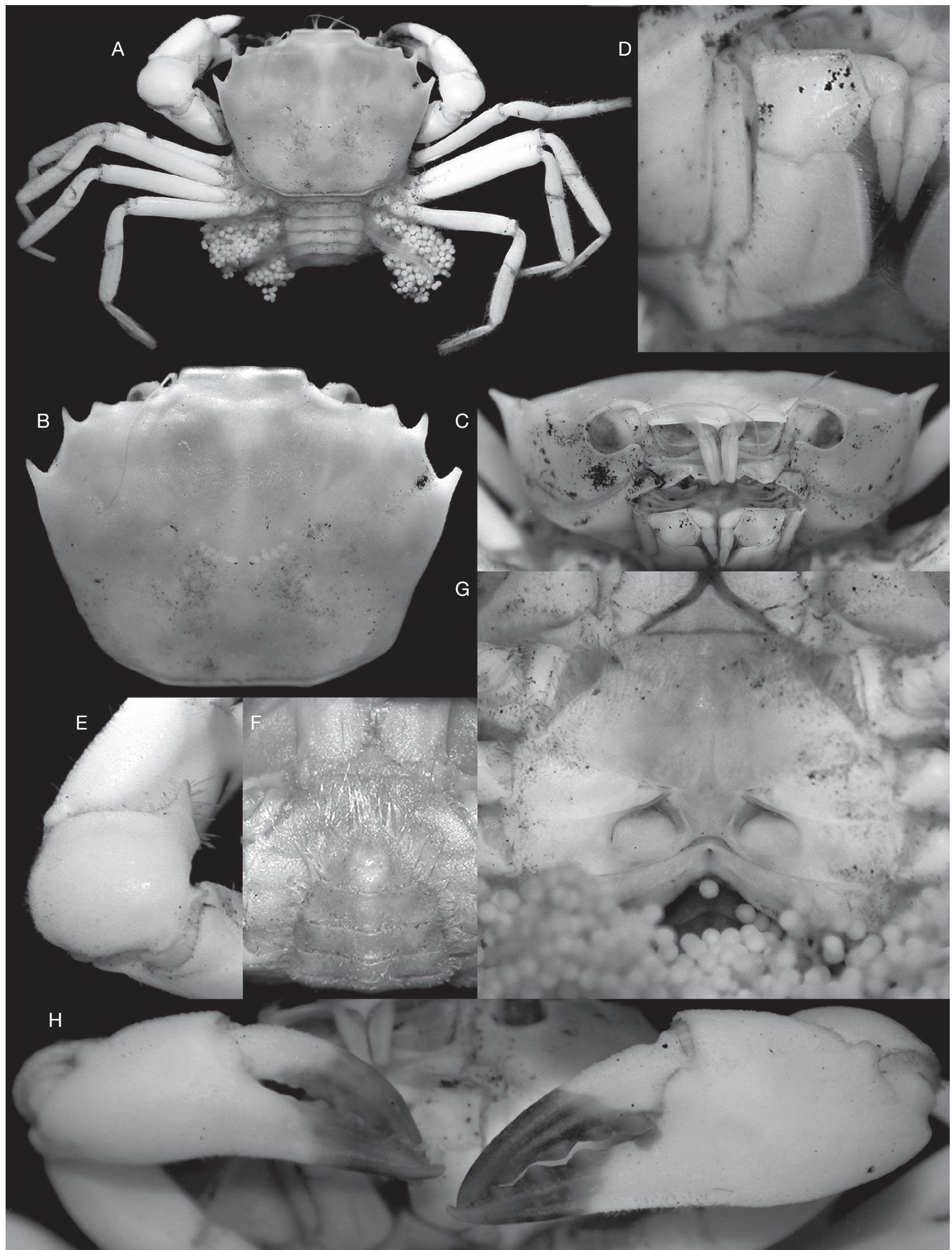

FIG. 9. - Carcinoplax longipes (Wood-Mason, 1891): A-E, G, H, ovigerous $\odot(10.8 \times 14.3 \mathrm{~mm})(Z R C 2018.1424)$, Indonesia; F, $\circ(9.9 \times 12.9 \mathrm{~mm})($ ZRC 2018.1424$)$ Indonesia. A, overall habitus; B, dorsal view of carapace; C, frontal view of cephalothorax; D, right third maxilliped; E, dorsal view of carpus of right cheliped; $\mathbf{F}$, thoracic sternum and pleon; $\mathbf{G}$, sternopleonal cavity and vulvae; $\mathbf{H}$, outer view of chelae. 
Not Carcinoplax longipes - Chen 1984: 189 [in key], 195, 197, fig. 6 [East China Sea]. — Ikeda 1998: 15, 42, 135, pl. 55 [Japan] (=C. verdensis Rathbun, 1914).

TYPe MATERIAL. - Syntypes. Andaman Sea. ơ $(8.5 \times 11.7 \mathrm{~mm})$, juvenile female from Investigator, stn 56, deposited at Zoological Survey of India, Kolkata.

Type locality. - Andaman Sea, 403-439 m.

Diagnosis. - Carapace (Figs 6A, B; 7A, B; 8A, B; 9A, B) quadrate, slightly wider than long $(1.3 \times$ wider than long in two topotypes); slightly convex, smooth. Front (Figs 6C; 7C, D; 8C, D; 9C) slightly sinuous, notch between front, inner edge of supraorbital border absent. Truncated or short triangular tooth on outer orbital angle; two slender, acute-tipped, curved anterolateral teeth on each side of carapace. Short granules on subhepatic, pterygostomial regions (Fig. 7C, D), becoming more pronounced in pterygostomial crest, ridge. Posterior margin of epistome (Figs 6C; 7C, D; 8C, D; 9C) short, straight, deep u- or v-shaped notch on each lateral margin. Nearly all distal portion of fingers dark brown in males, about half in females (Figs 8H; 9H; 27A-C). "Window" not observed on outer surface of cheliped propodus. Inner (ventral), distal margin of cheliped carpus (Figs 5E; 6E; 7F; 8F; 9E) with triangular, acute tipped tooth. P2-P5 (Figs 6A; 7A; 8A; 9A; 26A-C) long, slender. Male pleon (Figs 6F; 8G) proportionally wide. G1 (Fig. 23I, J, K) slender; pointed tip with scattered spinules; G2 (Fig. 23L) slender, slightly longer than G1, slightly curved flagellum, tip with two lateral spinules.

MATERIAL EXAMINED. - India • 1 \%, $10.8 \times 14.9 \mathrm{~mm}, 1 \mathrm{o}^{7}, 8.6 \times$ $11.0 \mathrm{~mm}$; off Travancore coast; Investigator; USNM 4691.

Indonesia $\bullet 1$ ovigerous $9,10.8 \times 14.3 \mathrm{~mm}$; SJADES; stn CP22, E. Sunda Strait, Java, $06^{\circ} 46.458^{\prime} \mathrm{S}, 105^{\circ} 07.068^{\prime} \mathrm{E}$; $864-870 \mathrm{~m}$ depth; 27.III.2018; ZRC 2018.1420 • 1 0', $8.3 \times 9.9$ mm; SJADES; stn CP23; E. Sunda Strait, Java; $06^{\circ} 46.739^{\prime} S, 105^{\circ} 09.239^{\prime} E ; 559$ $571 \mathrm{~m}$ depth; 27.III.2018; ZRC 2018.1421 • $10^{\prime \prime}, 9.0 \times 12.4 \mathrm{~mm}$; SJADES; stn CP33, E. Indian Ocean south of Java; 07'42.912'S, $107^{\circ} 36.559^{\prime} \mathrm{E}$; 312-525 m depth; 29.III.2018; ZRC 2018.1422・1 ovigerous $ᄋ$, cl $8.5 \mathrm{~mm}$, carapace damaged, $1 \mathrm{o}^{7}, 7.9 \times 10.5 \mathrm{~mm}$; SJADES; stn CP35, E. Indian Ocean; 0747.677'S, 10741.904'E; 603-686 m depth; 29.III.2018; ZRC 2018.1423 • 4 ovigerous $9,6.2$ $\times 8.0 \mathrm{~mm}$ to $7.7 \times 9.5 \mathrm{~mm}, 12 \mathrm{o}^{7}, 7.3 \times 9.4 \mathrm{~mm}$ to $9.9 \times 13.9 \mathrm{~mm}$; SJADES; stn CP39, E. Indian Ocean; $08^{\circ} 15.885^{\prime} \mathrm{S}, 109^{\circ} 10.163^{\prime} \mathrm{E}$ 528-637 m depth; 31.III.2018; ZRC 2018.1424 • 1 juvenile o , 6.0 $\times 7.8 \mathrm{~mm}$; SJADES; stn DW46, E. Indian Ocean; 0747.716'S, $107^{\circ} 44.896$ 'E; $540-654 \mathrm{~m}$ depth; 1.IV.2018 2 ovigerous $\$$, 7.6 $\times 9.6 \mathrm{~mm}, 6.7 \times 8.1 \mathrm{~mm}$; SJADES; stn CP47, E. Indian Ocean; 0747.972'S, $107^{\circ} 45.298^{\prime} \mathrm{E}$; 476-530 m depth; 1.IV.2018; MZB • $10^{\prime \prime}$, $7.9 \times 9.9 \mathrm{~mm}$; SJADES; stn CP48, E. Indian Ocean; 07 $51.120^{\prime} \mathrm{S}$, $107^{\circ} 46.245^{\prime} \mathrm{E}$; 637-689 m depth; 1.IV.2018; MZB • 2 \% , 2 ovigerous ? , $20^{7}$, larger one $9.5 \times 12.9 \mathrm{~mm}$; stn CP51, E. Indian Ocean; $07^{\circ} 04.874^{\prime} \mathrm{S}, 1^{\circ} 06^{\circ} 25.396^{\prime} \mathrm{E}$; $569-657 \mathrm{~m}$ depth; 2.IV.2018; ZRC $2018.1427 \bullet 1$ 우, 1 ovigerous ㅇ, 1 ơ, $10.8 \times 14.4 \mathrm{~mm}$; same data as ZRC 2018.1427; MZB.

COlOUR IN LiFE. — Faded yellowish orange to orange brown (Fig. 27A-C).

Geographical Distribution. - Andaman Sea and Indian Ocean south of Java.

DEPTH. - Present in samples collected at depths of 312-870 m.

\section{REMARKS}

See Remarks for C. abyssicola.

Wood-Mason (in Wood-Mason \& Alcock 1891) described Nectopanope longipes on the basis of a male and a juvenile female from station 56 from a depth of 220-240 fathoms
$(=402-439 \mathrm{~m})$. He provided measurements for one specimen $(8.5 \times 11.7 \mathrm{~mm})$ but did not indicate which one it was, although it is probably the male as this is the adult size for this species. He did not indicate where the site was but the data in Anonymous (1914) indicate that station 56 was between North and South Sentinel I. in the Andamans and was collected between 24 and 25 April 1889. Both specimens are therefore syntypes. Alcock (1900) listed 20 specimens from Andamans and off Travancore.

Serène \& Lohavanijaya (1973: pl. 14, fig. D) figured a male "cotype" measuring $10.0 \times 12.0 \mathrm{~mm}$ deposited at the Zoological Survey of India, Kolkata, but they did not indicate where or from which station it was from. It is not possible to be sure if it is part of the syntype series and/or if the different measurements (original size was given as $8.5 \times$ $11.7 \mathrm{~mm}$ ) are due merely to them being differently measured. The Investigator specimens we examined (USNM 4691) and those reported by Castro (2007) are all from Travancore and as such, cannot be part of the type series.

Ikeda (1998: 135$)$ recorded a male $(16.0 \times 22.0 \mathrm{~mm})$ and a female $(17.7 \times 25.0 \mathrm{~mm})$ "Carcinoplax longipes" from 250 $300 \mathrm{~m}$ depth in Sagami Bay, Japan. Both specimens agree well with what is here identified as $C$. verdensis s. str. The figure of a fresh specimen (Ikeda 1998: pl. 55, fig. 1) also agrees well with the fresh colours of $C$. verdensis we have observed in specimens from the Philippines (Fig. 28A-F). On the basis of this, as well as on biogeography, it is also likely that the material listed as "C. longipes" from Japan by Miyake (1991: 220), Takeda et al. (2006: 204) and Takeda \& Yaganisawa (1985: 61) also belong to $C$. verdensis as presently defined. Both these species have proportionately longer ambulatory legs than C. abyssicola.

The name Nectopanope longipes was actually first used in Anonymous (1891: 56) but both these taxa are nomina nuda. Wood-Mason (in Wood-Mason \& Alcock 1891) validated the names and included $N$. rhodobaphes as a second new species. Huys et al. (2014) clarified the nomenclature of these species, and argued that Nectopanope rhodobaphes is the type species of Nectopanope Wood-Mason in Wood-Mason \& Alcock, 1891. Alcock $(1898,1899)$ later treated $N$. longipes as a species of Carcinoplax. Nectopanope is now regarded as a member of the Euryplacidae Stimpson, 1871 sensu Castro \& $\mathrm{Ng}$ (2010) (see Ng et al. 2019).

Carcinoplax specularis Rathbun, 1914 (Figs 10A-H; 11A-I; 12A-I; 25A-E; 27D)

Carcinoplax specularis Rathbun, 1914: 143 [Philippines].

Carcinoplax specularis - Serène 1968: 90 [in list]. — Sakai 1969: 270, fig. 15c [holotype]. — Takeda \& Yaganisawa 1985: 61 [in list] [Japan]. — Guinot 1989: 296, figs 25, 34; pl. 8, figs A-D [holotype] [Philippines]. — Ho et al. 2004: 659, fig. 6F (colour) [Taiwan]. $\mathrm{Ng}$ et al. 2008: 80 [in list].

?Carcinoplax specularis - Serène \& Vadon 1981: 119, 120, 123, 126 [Philippines]. 


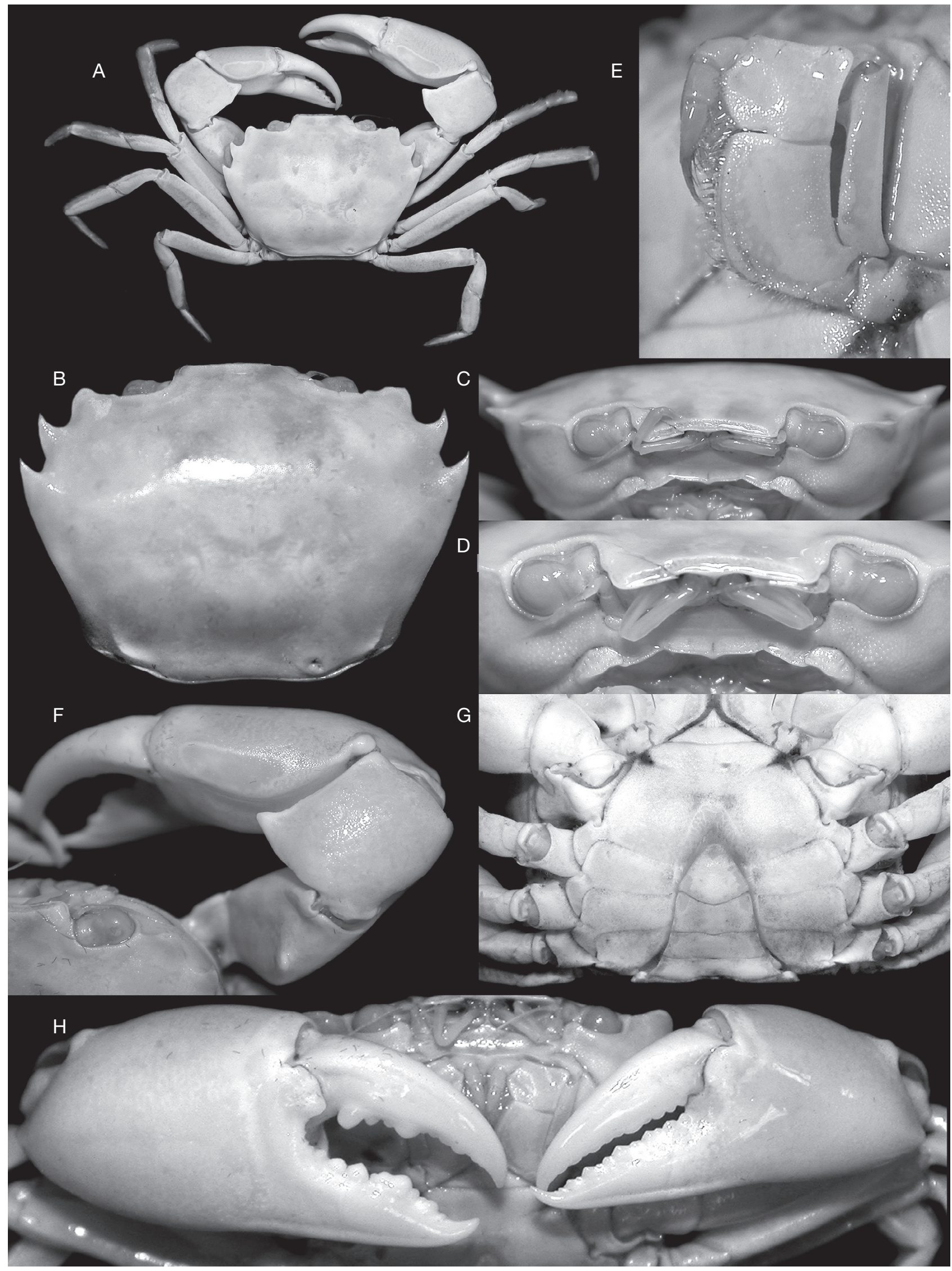

FIG. 10. - Carcinoplax specularis Rathbun, 1914, holotype ơ $(16.7 \times 23.0 \mathrm{~mm})$ (USNM 46164), Philippines: A, overall habitus; B, dorsal view of carapace; C, frontal view of cephalothorax; D, posterior margin of epistome; E, left third maxilliped; $\mathbf{F}$, right cheliped; $\mathbf{G}$, thoracic sternum and pleon; $\mathbf{H}$, outer view of chelae. 


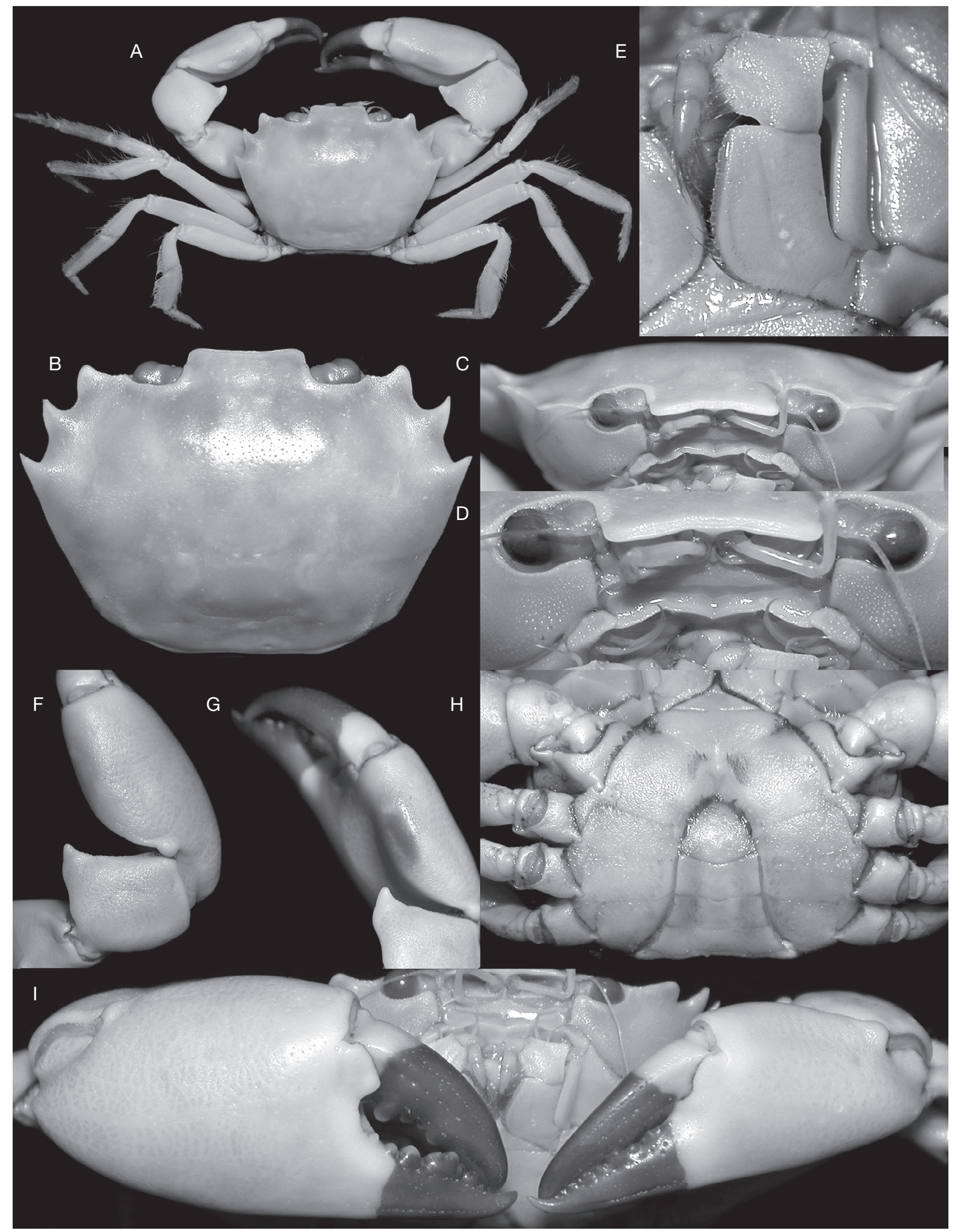

FIG. 11. - Carcinoplax specularis Rathbun, 1914, ơ $(18.4 \times 25.8 \mathrm{~mm})($ ZRC 2001.0134), Taiwan: A, overall habitus; B, dorsal view of carapace; C, frontal view of cephalothorax; D, posterior margin of epistome; $\mathbf{E}$, left third maxilliped; $\mathbf{F}$, dorsal view of carpus of right cheliped; $\mathbf{G}$, dorsal view of right chela; $\mathbf{H}$, thoracic sternum and pleon; I, outer view of chelae. 


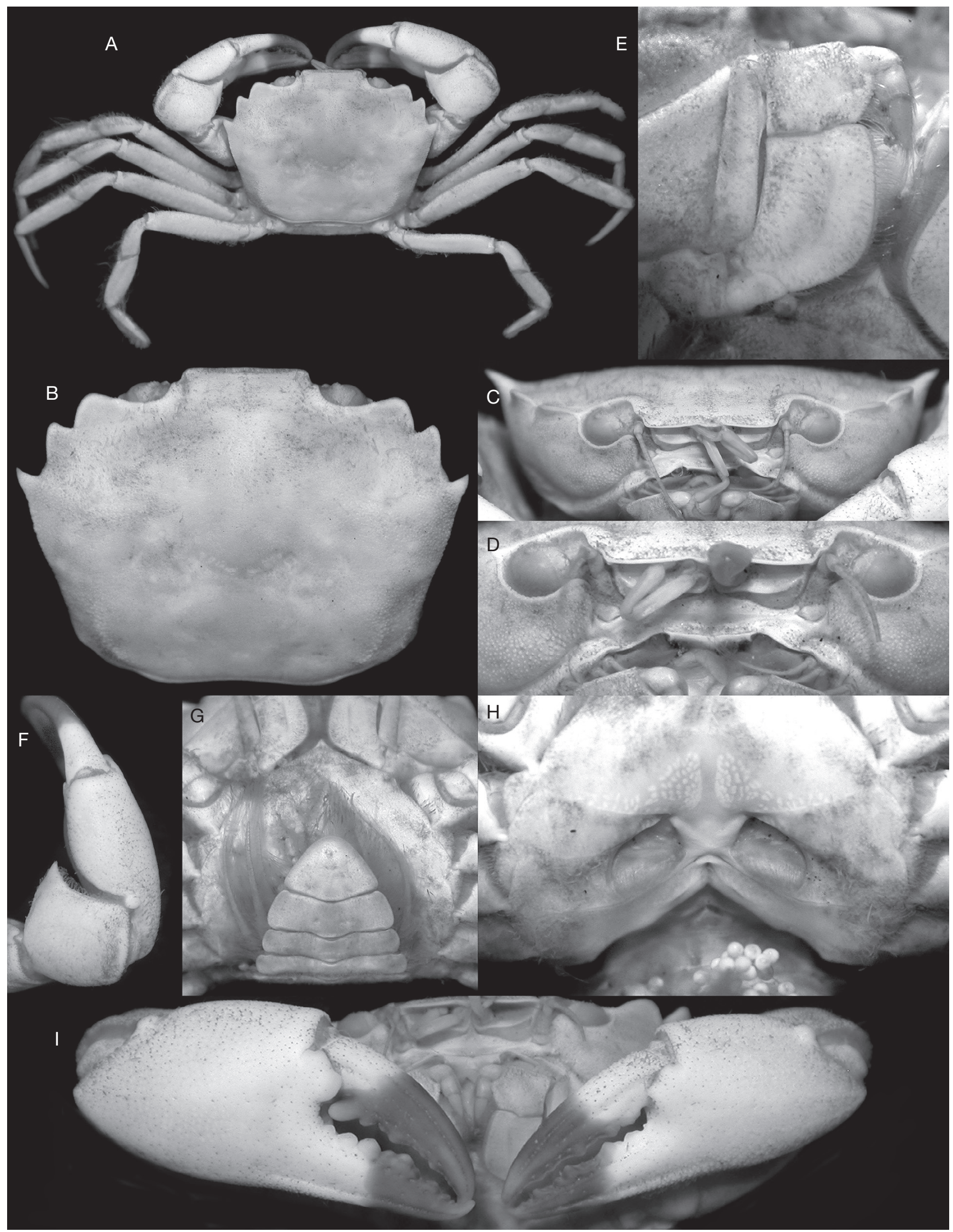

FiG. 12. - Carcinoplax specularis Rathbun, 1914, o $(12.4 \times 16.7 \mathrm{~mm})$ (MNHN-IU-2016-125), Taiwan: A, overall habitus; B, dorsal view of carapace; C, frontal view of cephalothorax; D, posterior margin of epistome; $\mathbf{E}$, right third maxilliped; $\mathbf{F}$, dorsal view of carpus of right cheliped; $\mathbf{G}$, thoracic sternum and pleon; $\mathbf{H}$, sternopleonal cavity and vulvae; I, outer view of chelae. 
Carcinoplax specularis [part] -Castro 2007: 640 [Taiwan, Philippines]. Carcinoplax longipes - Sakai 1976: 524 [in key], 527, fig. 281 [Japan] (not C. longipes (Wood-Mason, 1891)).

?Carcinoplax longipes - Miyake 1991: 220 [in list] [Japan]. — Takeda et al. 2006: 204 [in list] [Japan]. — Takeda \& Yaganisawa 1985: 61 [in list] [Japan] (not C. longipes (Wood-Mason, 1891), either C. specularis s. str. or C. verdensis Rathbun, 1914).

Not Carcinoplax specularis [part] - Castro 2007: 640 (= C. polita Guinot, 1989).

Not Carcinoplax specularis [part] - Castro 2007: 640. (= C. tuberosa Castro, 2007).

Not Carcinoplax specularis [part] - Castro 2007: 640 (= C. verdensis Rathbun, 1914).

Not Carcinoplax specularis [part] - Castro 2007: 641 (? = C. fasciata $\mathrm{Ng} \&$ Kumar, 2016)

Type Material. - Holotype. Philippines. ơ, $16.7 \times 23.0 \mathrm{~mm}$, Albatross; stn 5113; 17.I.1908; USNM 46164.

TYPE LOCALITY. - Philippines, off southern Luzon, Sombrero I., S. $7^{\circ} \mathrm{W}$., 9.5 miles, $13^{\circ} 51^{\prime} 30^{\prime \prime} \mathrm{N}, 120^{\circ} 50^{\prime} 30^{\prime \prime} \mathrm{E}, 159$ fathoms (=291 m).

MATERIAL EXAMINED. - Taiwan • $10^{7}, 14.2 \times 19.9 \mathrm{~mm}$; TAIWAN 2001; stn CP77, $24^{\circ} 54.2^{\prime} \mathrm{N}, 122^{\circ} 02.5^{\prime} \mathrm{E}$; 220-360 m depth; 7.V.2001; MNHN-IU-2016-122 (= MNHN-B29821) • 1 ơ, $16.5 \times 22.5 \mathrm{~mm}$; same data as MNHN-IU-2016-122; MNHN-IU-2016-123 (= MNHN-B29822); ・ 1 o", $18.4 \times 25.8 \mathrm{~mm}, 1$ ㅇ, $13.2 \times 17.8 \mathrm{~mm}$; TAIWAN 2001; stn CP85; $24^{\circ} 0.65^{\prime} \mathrm{N}, 122^{\circ} 0.64^{\prime} \mathrm{E} ; 255-390 \mathrm{~m}$ depth; 9.V.2001; ZRC 2001.0134・1 \%, ovigerous $10^{7}$; TAIWAN 2001; stn CP96; $24^{\circ} 04.2^{\prime} \mathrm{N}, 122^{\circ} 04.2^{\prime} \mathrm{E}$; $472-586 \mathrm{~m}$ depth; 18.V.2001; MNHN-IU-2016-124 (= MNHN-B29823) • 1 \& , $12.4 \times 16.7 \mathrm{~mm}$ TAIWAN 2001; stn CP104; $24^{\circ} 48.9^{\prime} \mathrm{N}, 122^{\circ} 05.3^{\prime} \mathrm{E}$; $365-447 \mathrm{~m}$ depth; 10.V.2001; MNHN-IU-2016-125 (= MNHN-B29824).

Philippines • $10^{7}, 12.5 \times 17.9$ mm; PANGLAO 2005; stn CP2359, Bohol Sea; $08^{\circ} 49.9^{\prime} \mathrm{N}, 123^{\circ} 34.9^{\prime} \mathrm{E}$; 437-476 m depth; 26.V.2005; ZRC 2018.1435 • 2 \%; PANGLAO 2005; stn CP2372, Dipolog Bay, Bohol Sea; $8^{\circ} 38.7^{\prime} \mathrm{N}, 123^{\circ} 16.0^{\prime} \mathrm{E}$; 27.V.2005; ZRC 2018.1436 - 1 \%, $13.9 \times 18.0$ mm; PANGLAO 2005; stn CP2407, Maribohoc Bay; 09 $41.3^{\prime} \mathrm{N}, 123^{\circ} 48.5^{\prime} \mathrm{E}, 256-268 \mathrm{~m}$ depth; ZRC 2006.0207 - $20^{\prime \prime}$; AURORA; stn CP2731, Luzon Sea; $15^{\circ} 22.44^{\prime} \mathrm{N}, 121^{\circ} 33.58^{\prime} \mathrm{E}$ - $15^{\circ} 24.48^{\prime} \mathrm{N}, 121^{\circ} 33.51^{\prime} \mathrm{E} ; 376-391 \mathrm{~m}$; 31.V.2007; ZRC 2018.1437 - 4 o, largest $10.5 \times 15.7 \mathrm{~mm}, 20^{\circ}$, larger one $1.0 \times 15.0 \mathrm{~mm}$; AURORA; stn CP2734, Luzon Sea; $15^{\circ} 56.41^{\prime} \mathrm{N}, 121^{\circ} 48.71^{\prime} \mathrm{E}$ $15^{\circ} 56.98^{\prime} \mathrm{N}, 121^{\circ} 49.21^{\prime} \mathrm{E}$; $453-460 \mathrm{~m}$ depth; 1.VI.2007; ZRC 2018.1438

DiAgnosis. - Carapace (Figs 10A, B; 11A, B; 12A, B) quadrate, slightly wider than long $(1.4 \times$ wider than long in holotype); slightly convex, marked by slight transverse elevations. Front (Figs 10C, D; 11C, D; 12C, D) straight, notch between front, inner edge of supraorbital border absent. Triangular or rounded tooth on outer orbital angle; two slender, acute or obtuse anterolateral teeth on each side of carapace. Small, short granules on subhepatic, pterygostomial regions (Figs 10D; 11D; 12D), becoming slightly more pronounced in pterygostomial crest, ridge. Posterior margin of epistome (Figs 10D; $11 \mathrm{D} ; 12 \mathrm{D})$ straight, slightly pointed medially, slight gap or notch on each lateral margin. Distal half of fingers dark brown in females (Fig. 12A, F, I), two-thirds in males (Fig. 11A, I). Smooth, oblong "window" on inner, dorsal surface of cheliped propodi of some males, including holotype (Figs 10F; 11G). Inner (ventral), distal margin of cheliped carpus (Figs 10F; 11F, G; 12F) with short, blunt or acutetipped tooth. P2-P5 (Figs 10A; 11A; 12A; 27D) moderately stout in appearance. Male pleon (Figs 10G; 11F) proportionally narrow. G1 (Fig. 25A-D; Guinot 1989: fig. 34A) slender; truncated tip with scattered spinules that do not reach distal margin; G2 (Fig. 25E; Guinot 1989: fig. 34B) slender, nearly equal or slightly longer than G1, slightly curved flagellum, tip with two lateral spinules.

COLOUR IN LIFE. - Light orange with a semi-circular row of small white spots on each side of the carapace (Fig. 27D; Ho et al. 2004: fig. 6F).

Geographical Distribution. - Japan, Taiwan, and Philippines.

DертH. - Present in samples collected at depths of 220-586 m.

\section{REMARKS}

Larger males show a "window", an oblong, slightly darker spot on the inner, dorsal surface of the cheliped propodi (Figs 10F; $11 \mathrm{G})$, that was previously noted in the holotype by Rathbun (1914) and Guinot (1989). It has not been observed in females. Such a "window" was also observed by us in C. abyssicola and C. adelphia n. sp. For differences with C. adelphia n. sp., see the remarks for the latter species.

Carcinoplax specularis was found together with C. verdensis and C. jugum n. sp. from one station in the Philippines (CP2359).

Three specimens of $C$. tuberosa Castro, 2007 from Kai Is, Indonesia (MNHN-IU-2016-98 (= MNHN-B29385), MNHN-IU-2016-101 (= MNHN-B29390), and MNHNIU-2016-102 (= MNHN-B29392)) were erroneously identified as C. specularis by Castro (2007).

Two ovigerous females from the Maldives (John Murray Expedition, stn $143,05^{\circ} 15.8^{\prime} \mathrm{N}, 73^{\circ} 22.8^{\prime} \mathrm{E}-05^{\circ} 13.7^{\prime} \mathrm{N}$, 73⒉6'E, $797 \mathrm{~m}$ depth; 30.III.1934, MNH 2007.64-65) identified as C. specularis by Castro (2007: 641) most probably belong to a different species of Carcinoplax, with $\mathrm{Ng} \&$ Kumar (2016) suggesting it was likely to be $C$. fasciata $\mathrm{Ng} \&$ Kumar, 2016 instead. The specimens in the NHM could not be located for re-examination (see Ng \& Kumar 2016: 199).

Carcinoplax verdensis Rathbun, 1914

(Figs 13A-J; 14A-H; 15A-G; 24A-H; 28A-F)

Carcinoplax verdensis Rathbun, 1914: 143 [type locality: southern Luzon, Philippines]. — Tesch 1918: 154 [in list]. — Estampador 1937: 533 [in list]; 1959: 89 [in list] [Philippines]. — Serène 1968: 90 [in list]. - Sakai 1969: 269 [in list], fig. 15d [holotype]. Serène \& Lohavanijaya 1973: 62 [in list], 65 [in key]. — Serène $\&$ Vadon 1981: 119, 123, 126 [Philippines]. — Guinot 1989: 300, fig. 22; pl. 9, figs D-F [holotype] [Philippines]. — Ng et al. 2008: 80 [in list].

Carcinoplax longipes - Chen 1984: 189 [in key], 195, 197, fig. 6 [East China Sea]. - Ikeda 1998: 15, 42, 135, pl. 55 [Japan] (not C. longipes (Wood-Mason, 1891)).

Carcinoplax aff. longipes - Guinot 1989: 305, figs 27, 35, 36; pl. 10, figs D-G [Philippines].

Carcinoplax specularis [part] - Castro 2007: 640 [Philippines].

Not Carcinoplax verdensis - Selvaraj \& Kathirvel 1980: 159, figs 1, 2 [India] (C. indica Doflein, 1904). 


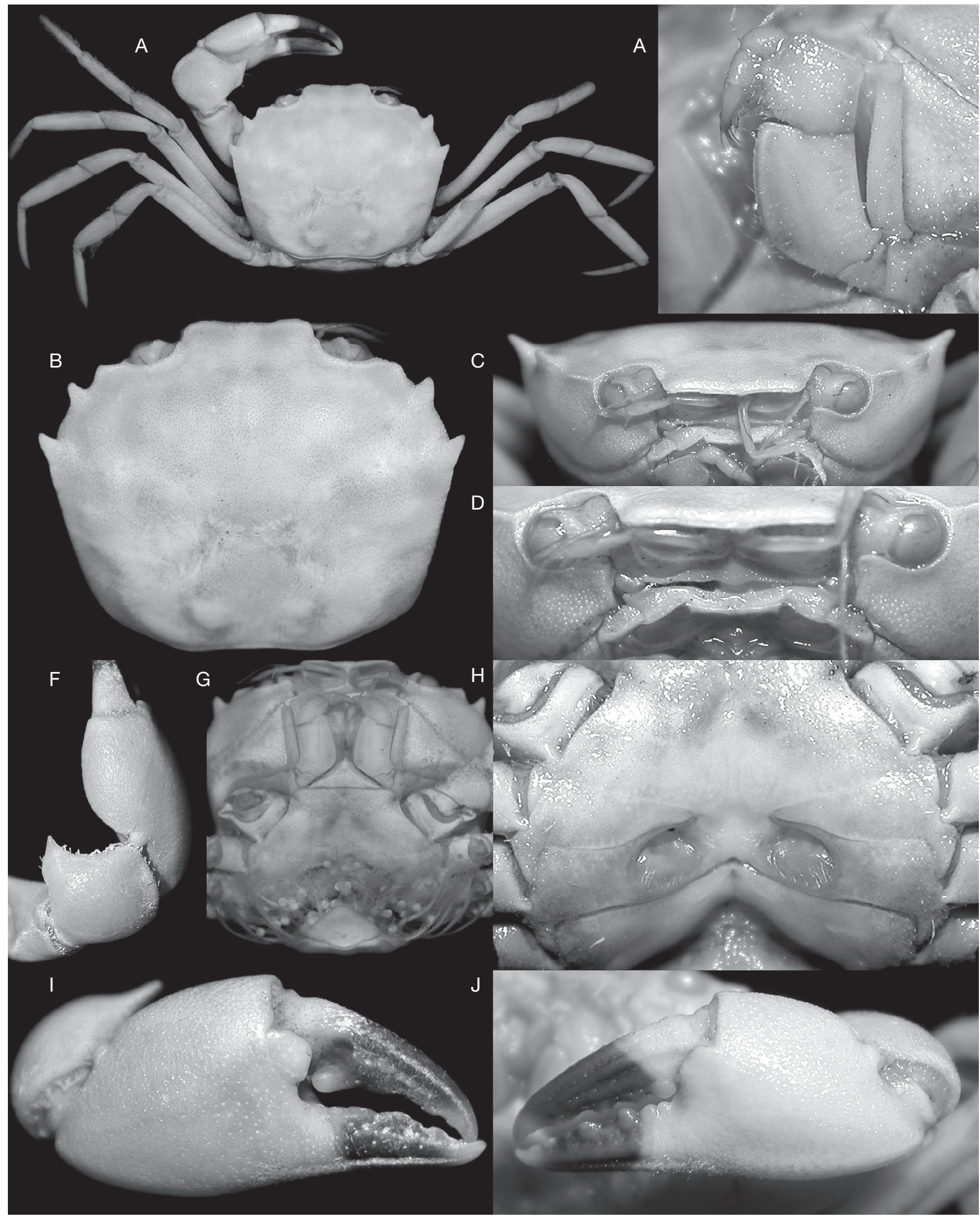

FIG. 13. - Carcinoplax verdensis Rathbun, 1914, holotype ovigerous o (10.5 × $13.0 \mathrm{~mm})$ (USNM 46167), Philippines: A, overall habitus; B, dorsal view of carapace; C, frontal view of cephalothorax; $\mathbf{D}$, posterior margin of epistome; $\mathbf{E}$, left third maxilliped; $\mathbf{F}$, dorsal view of carpus of right cheliped; $\mathbf{G}$, thoracic sternum and pleon; H, sternopleonal cavity and vulvae; I, outer view of right chela; J, outer view of left chela. 


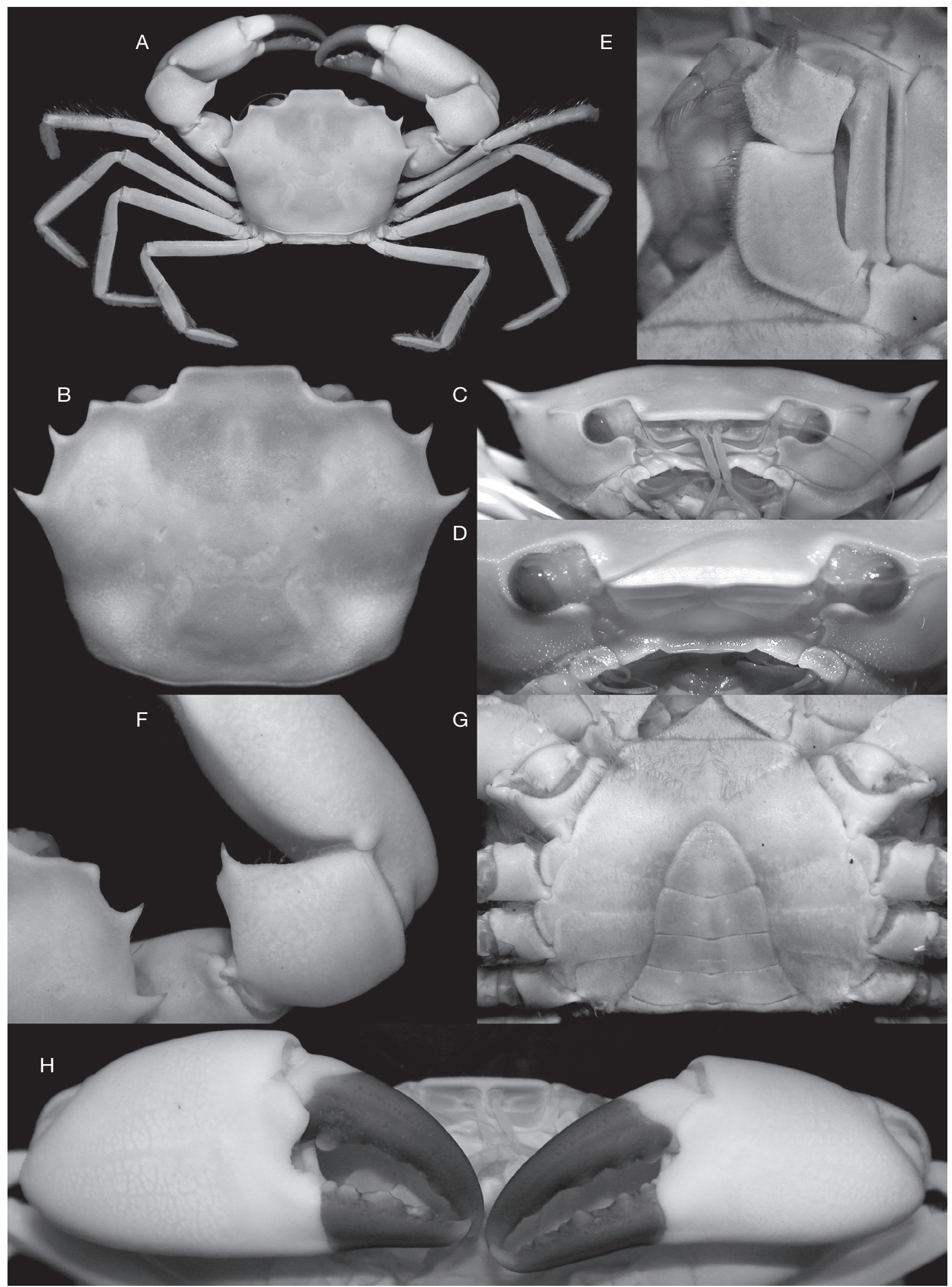

FIG. 14. - Carcinoplax verdensis Rathbun, 1914, ơ (15.7 × 21.4 mm) (ZRC 2019.0549), Philippines: A, overall habitus; B, dorsal view of carapace; C, frontal view of cephalothorax; D, posterior margin of epistome; $\mathbf{E}$, left third maxilliped; $\mathbf{F}$, dorsal view of carpus of right cheliped; $\mathbf{G}$, thoracic sternum and pleon; $\mathbf{H}$, outer view of chelae. 


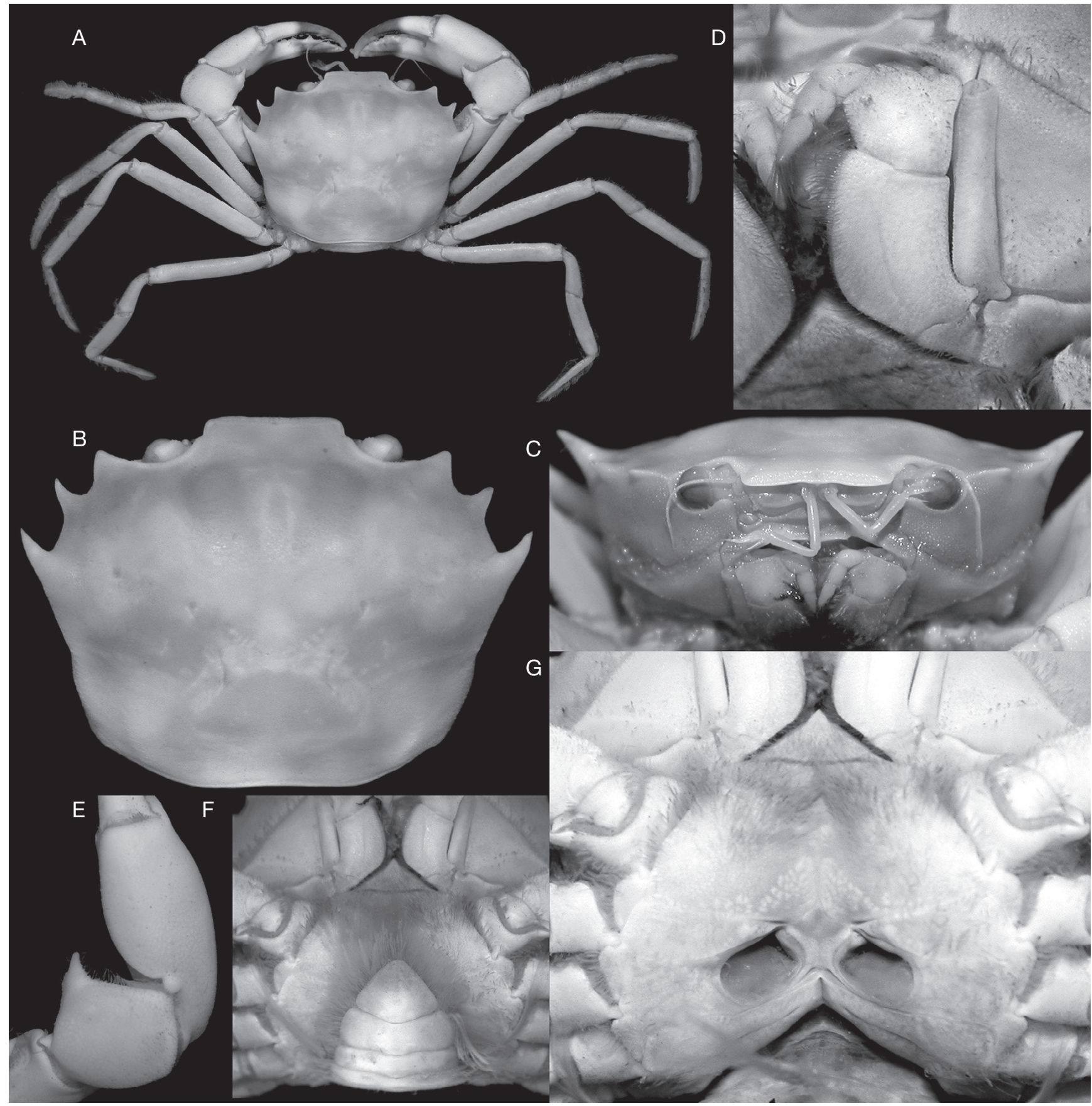

FIG. 15. - Carcinoplax verdensis Rathbun, 1914, $\odot(16.3 \times 21.9 \mathrm{~mm})($ ZRC 2019.0546), Philippines: A, overall habitus; B, dorsal view of carapace; C, frontal view of cephalothorax; $\mathbf{D}$, left third maxilliped; $\mathbf{E}$, dorsal view of carpus of right cheliped; $\mathbf{F}$, thoracic sternum and pleon; $\mathbf{G}$, sternopleonal cavity and vulvae.

Type Material. - Holotype. Philippines - Ovigerous $\$$, $10.5 \times$ $13.0 \mathrm{~mm}$; Albatross; stn 5119; USNM 46167.

Type Locality. — Philippines, off Sombrero I., Verde I. Passage, 159-394 fathoms (= 291-721 m),

MATERIAL EXAMINED. - Taiwan $110^{7}$ (badly damaged); stn CP19, southwestern Taiwan; $22^{\circ} 24.2^{\prime} \mathrm{N} 120^{\circ} 10.2^{\prime} \mathrm{E}-22^{\circ} 23.8^{\prime} \mathrm{N} 120^{\circ} 09^{\prime} \mathrm{E}$ 467-634 m depth; coll. T.-Y. Chan; 29.VII.2000; ZRC 2001.2216 Philippines. 1 ovigerous , holotype $10.5 \times 13.0 \mathrm{~mm}$; Albatross, stn
5119, off Sombrero I., Verde I. Passage; 291-721 m depth; 21.I.1908; USNM 46167 • 1 o; MUSORSTOM 3, stn CP116; $12^{\circ} 32^{\prime} \mathrm{N}$, $120^{\circ} 47^{\prime} \mathrm{E}$; 804-812 $\mathrm{m}$ depth; 3.VI.1985; MNHN-IU-2016-8001 • 2 o , $9.2 \times 12.1 \mathrm{~mm}, 12.0 \times 16.7 \mathrm{~mm}, 8 \mathrm{o}^{7}$ ( 2 with bopyrids); MUSORSTOM 3, Bohol, Balicasag I., off Panglao I., tangle nets of local fishermen; $09^{\circ} 31^{\prime} 00.2^{\prime \prime} \mathrm{N}, 123^{\circ} 40^{\prime} 50.5^{\prime \prime} \mathrm{E} ; 200-300 \mathrm{~m}$ depth; XII.2000; ZRC 2001.0395 • 1 \%; MUSORSTOM 3, tangle nets of local fishermen; $09^{\circ} 31^{\prime} 00.2^{\prime \prime} \mathrm{N}, 123^{\circ} 40^{\prime} 50.5^{\prime \prime} \mathrm{E}$; 200 $300 \mathrm{~m}$ depth; XII.2000; ZRC 2019.0544 1 o", $14.9 \times 20.2 \mathrm{~mm}$; PANGLAO 2005, stn CP2332, Maribohoc Bay; 09³8.8'N, 12345.9'E; 396-418 m depth; 22.V.2005, ZRC 2019.0547, 
ex ZRC 2006.0214 (part) • 1 \% $5.8 \times 8.1 \mathrm{~mm}$; PANGLAO 2005, stn DW2338, off Balicasag Island; $09^{\circ} 30.7^{\prime} \mathrm{N}, 123^{\circ} 42.4$ 'E; 347-349 m depth; 23.V.2005; ZRC 2019.0548・1 0', 19.0 $\times 27.7 \mathrm{~mm}$; PANGLAO 2005, stn CP2339, off Balicasag Island; $09^{\circ} 31.9^{\prime} \mathrm{N}, 123^{\circ} 43.7^{\prime} \mathrm{E}, 164-176 \mathrm{~m}$ depth; 23.V.2005; ZRC $2019.0550 \bullet 1$ o , $10.9 \times 14.4 \mathrm{~mm}$; same data as ZRC 2019.0550; ZRC 2019.0573 • 1 o", $3.8 \times 4.8 \mathrm{~mm}$; PANGLAO 2005, stn CP2359, Bohol Sea; 0849.9'N, 12334.9'E; 437-476 m depth; 26.V.2005, ZRC 2019.0553・1 ơ, $15.7 \times 21.4 \mathrm{~mm}, \mathrm{ZRC}$ $2019.0549 \bullet 1$ juvenile ơ; same data as ZRC 2019.0549; ZRC $2009.0990 \bullet 2$ o , $12.4 \times 17.1 \mathrm{~mm}, 13.0 \times 18.3 \mathrm{~mm}$; PANGLAO 2005, stn CP2361, Bohol Sea; 0853.1'N, 12333.5'E; 516-543 m depth; 26.V.2005; ZRC 2019.0554 • 11 \& (1 with rhizocephalan), $40^{7}, 1$ juvenile; PANGLAO 2005, stn CP2384, off Aligbay Island; $08^{\circ} 46.2^{\prime} \mathrm{N}, 123^{\circ} 16.1^{\prime} \mathrm{E}$; 624-647 $\mathrm{m}$ depth; 29.V.2005; ZRC 2019.0546 • $10^{\prime \prime}, 16.9 \times 23.0$ mm; PANGLAO 2005, stn CP2385; $08^{\circ} 51.0^{\prime} \mathrm{N}, 123^{\circ} 10.0^{\prime} \mathrm{E}, 982-989$ m depth; 29.V.2005; ZRC 2009.1003 • $10^{7}$, with sacculinid; PANGLAO 2005 stn CP2386; 08 $49.3^{\prime} \mathrm{N}, 123^{\circ} 01.9^{\prime} \mathrm{E}, 2120-2149 \mathrm{~m}$ depth (?); 29.V.2005; ZRC 2019.0556・1 \&, $10.9 \times 14.6 \mathrm{~mm}$; PANGLAO 2005, stn CP2388, Maribohoc Bay; 0926.9’ N, $123^{\circ} 34.5^{\prime} \mathrm{E}$; 762-786 m depth; 30.V.2005, ZRC 2019.0551 • $20^{\prime \prime}, 11.6 \times$ $15.4 \mathrm{~mm}, 11.0 \times 14.6 \mathrm{~mm}$; same data as ZRC 2019.0551; ZRC $2019.0571 \cdot 20^{7}$, larger one $19.2 \times 27.7 \mathrm{~mm}, 2$ \% PANGLAO 2005, stn CP2389, Bohol Sea; 09²7.9'N, 12338.4’E; 784786 m depth; 30.V.2005; ZRC 2019.0555 • $20^{\prime \prime}, 9.6 \times 12.0$, $12.8 \times 17.1 \mathrm{~mm}$; PANGLAO 2005, stn CP2394, off Balicasag Island; $09^{\circ} 28.6^{\prime} \mathrm{N}, 123^{\circ} 40.0^{\prime} \mathrm{E}$; 470-566 m depth; 30.V.2005: ZRC $2019.0557 \cdot 10^{\circ}, 10.0 \times 13.4 \mathrm{~mm}$; same data as ZRC 2019.0557; ZRC 2019.0574 • 3 o", $8.7 \times 10.1 \mathrm{~mm}, 9.8 \times$ $11.8 \mathrm{~mm}, 17.6 \times 13.7 \mathrm{~mm}$; PANGLAO 2005. stn CP2396, west Panglao, on sandy bottom; $09^{\circ} 36.3^{\prime} \mathrm{N} 123^{\circ} 42.0^{\prime} \mathrm{E}$; 673 715 m depth; 31.V.2005; ZRC 2016.0446 • 2 o $^{\prime 7}, 10^{\circ}, 13.2 \times$ $16.1 \mathrm{~mm}$ with sacculinid; PANGLAO 2005, stn CP2405, on sandy-muddy bottom; $09^{\circ} 39.0^{\prime} \mathrm{N} 123^{\circ} 46.1^{\prime} \mathrm{E}, 1$.VI.2005; ZRC 2006.0199 10 o", 1 \% , (both with bopyrids); PANGLAO 2005, stn CP2358, Bohol Sea; 08 $52.1^{\prime} \mathrm{N}, 123^{\circ} 37.1^{\prime} \mathrm{E} ; 569-583 \mathrm{~m}$ depth; 26.V.2005; ZRC 2016.0439 • $10^{\prime \prime}$ (with bopyrid); PANGLAO 2005, stn CP2396, Maribojoc Bay, 09³6.3'N, 12342.0'E; 609$673 \mathrm{~m}$ depth; 31.V.2005; ZRC 2016.0447 • 1 o", (with bopyrid); PANGLAO 2005, stn CP2405, Maribojoc Bay; 09³9.0'N 12346.1'E; 387-453 m depth; 1.VI.2005; ZRC 2016.0436 - 1 o (with bopyrid), station unknown; Bohol Sea; V-VI 2005; ZRC 2016.0441 • 1 ㅇ, $12.8 \times 17.9 \mathrm{~mm}$; AURORA 2007, stn CP2673, Luzon Sea; $14^{\circ} 59.83^{\prime} \mathrm{N}, 121^{\circ} 43.90^{\prime} \mathrm{E}-15^{\circ} 01.44^{\prime} \mathrm{N}$ $121^{\circ} 44.75^{\prime} \mathrm{E}$; 431-493m; 22.V.2007; ZRC 2019.0559・1 우, $7.9 \times 10.9 \mathrm{~mm}$; AURORA 2007, stn DW2692, Luzon Sea; $14^{\circ} 40.15^{\prime} \mathrm{N}, 123^{\circ} 40.06^{\prime} \mathrm{E}-14^{\circ} 40.45^{\prime} \mathrm{N}, 123^{\circ} 40.59^{\prime} \mathrm{E}$; $261-$ 272 m depth; 26.V.2007; ZRC 2019.0560.

South China Sea 1 o , ovigerous $9.4 \times 13.0 \mathrm{~mm}$; NANHAI 2014, stn CP4117, LL4; $20^{\circ} 00.8788^{\prime} \mathrm{N}, 11^{\circ} 08.7974$ ' E; 333 $421 \mathrm{~m}$ depth; 11.I.2014, ZRC 2019.0561 • 1 ㅇ, 1 o'; same data as stn CP4117; ZRC 2019.0210 • 1 \%; ZHONGSHA 2015, stn CP4155, northeast of Macclesfield Bank; $16^{\circ} 13.60^{\prime} \mathrm{N}$, $115^{\circ} 01.61^{\prime} \mathrm{E} ; 510-526 \mathrm{~m}$ depth; 28.VII.2015; ZRC 2019.0562 - 1 on $^{\text {, }} 11.1 \times 16.0 \mathrm{~mm}$; ZHONGSHA 2015, stn CP4165, south

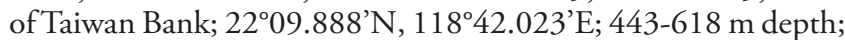
1.VIII.2015; ZRC 2019.0563・1 1 ; ZHONGSHA 2015, stn CP4166, south of Taiwan Bank; $22^{\circ} 07.6245^{\prime} \mathrm{N}, 118^{\circ} 43.3003^{\prime} \mathrm{E}$; 587-756 m depth; 1.VIII.2015; ZRC 2019.0564・1 우, 6.8 $\times 8.8 \mathrm{~mm}$; ORI3 CRUISE, stn 9, Tungsha Is, $21^{\circ} 40.293^{\prime} \mathrm{N}$ $117^{\circ} 43.244^{\prime} \mathrm{E}-21^{\circ} 38.995^{\prime} \mathrm{N} 117^{\circ} 41.649^{\prime} \mathrm{E}$; $523-510 \mathrm{~m}$ depth; coll. I.-S. Chen; 9.VII.2011; ZRC 2019.0374.

DiagnOSIS. - Carapace (Figs 13A, B; 14A, B; 15A, B) quadrate, slightly wider than long $(1.4 \times$ wider than long in holotype); slightly convex, slight transverse elevations, slight tomentum.
Front (Figs 13C, D; 14C, D; 15C) straight, notch on each lateral margin absent or slight if present. Rounded, short tooth on outer orbital angle; two slender, acute-tipped anterolateral teeth on each side of carapace. Small, short granules on subhepatic, pterygostomial regions (Figs 13D; 14D), becoming more pronounced in pterygostomial crest, ridge; short granules on anterior, dorsal surface of carapace. Posterior margin of epistome (Figs 13D; 14D) straight, slight median emargination in some specimens, shallow notch on each lateral margin. Distal half of fingers dark brown in females (Figs 13A, I, J; 15A), two third in males (Fig. 14A, H). "Window" not observed on outer surface of cheliped propodus. Inner (ventral), distal margin of cheliped carpus (Figs 13F; 14F; 15E) with acute, conspicuous tooth. P2-P5 (Figs 13A; 14A; 15A; 28A-F) slender in appearance. Male pleon proportionally wide (Fig. 14G). G1 (Fig. 24A-C, E, G) slender; pointed tip with scattered spinules, abundant, almost reaching margin of tip in some individuals; G2 (Fig. 24D, F, H) slender, nearly equal or slightly longer than G1, slightly curved flagellum, tip with two lateral spinules.

COlOUR IN LIFE. - Orange carapace that intensifies with age, at least in females (Fig. 27D-F). The legs (P2-P5) of females show thin, red bands across the middle portion. Males are orange without any banding on the legs (Fig. 27A-C).

Geographical distribution. - Japan, East China Sea, Taiwan, Philippines, and South China Sea.

DEPTH. - Present in samples collected at depths of 164-989 m; $2120-2149 \mathrm{~m}$ in one station, possibly an error.

\section{REMARKS}

See Remarks for C. abyssicola.

The relatively long, acute, and conspicuous tooth on the inner distal angle of the cheliped carpus (Figs 13F; 14F; $15 \mathrm{E}$ ) is a good character to distinguish $C$. verdensis, with most specimens showing this character. No other species treated here has this character. Some specimens (e.g. 1 ㅇ, $12.8 \times 17.9 \mathrm{~mm}$, ZRC 2019.0559) have lower, more obtuse cheliped carpal spines, not acute and elongated as is typical specimens.

Guinot (1989), who only observed the holotype, separated C. verdensis because of the absence of the "window" of C. specularis, the acute anterolateral teeth, and relatively more slender legs (P2-P5). The ambulatory meri of $C$. verdensis are indeed one of the longest in the group (see remarks for C. abyssicola), although in a few specimens, the legs are somewhat shorter (e.g. Fig. 28E, F).

A very large $(54.0 \times 69.0 \mathrm{~mm})$ male specimen from southwestern India identified as $C$. verdensis by Selvaraj \& Kathirvel (1980: 159, figs 1, 2) is clearly not this species as presently defined. Carcinoplax verdensis does not grow to such a large size, and the general carapace facies and G1 structure also do not match. The photograph of the overall habitus is too poor to see distinguishing characters and it probably belongs to $C$. indica Doflein, 1904 instead. This species was described from the Andamans and is known to grow to very large sizes. The size of the Indian specimen also argues against it being C. longipes, C. fasciata $\mathrm{Ng} \&$ Kumar, 2016, or C. mistio $\mathrm{Ng} \&$ Mitra, 2019. 
Carcinoplax polita Guinot, 1989

(Figs 16A-H; 17A-I; 24I-O; 27G, H)

Carcinoplax polita Guinot, 1989: 298, figs 24, 37, pl. 8, figs E-H [type locality: southern Luzon, Philippines]. - Ng et al. 2008: 80 [in list].

Carcinoplax specularis [part] - Castro 2007: 640 [Taiwan, Philippines].

TyPe MATERIAL. - Holotype. South China Sea • o", $14.5 \times 20.4 \mathrm{~mm}$; MUSORSTOM 1, stn CP31; MNHN-IU-2008-10565 (= MNHNB10140); allotype ᄋ, $12.5 \times 16.9 \mathrm{~mm}$; MNHN-IU-2008-10584 (= MNHN-B10543); paratype o, $9.2 \times 12.2 \mathrm{~mm} ; \mathrm{MNHN}-$ IU-2008-10571 (= MNHN-B10268).

Type LOCALITY. — South China Sea, Philippines, southern Luzon, $187-195 \mathrm{~m}$

Material eXamined. - South China Sea • 1 o , $8.8 \times 12.7 \mathrm{~mm}$ NANHAI 2014, stn CP4116; $20^{\circ} 02.3211^{\prime} \mathrm{N}, 1^{\circ} 4^{\circ} 10.2157^{\prime} \mathrm{E}$; 262-298 m depth; 11.I.2014; ZRC 2018.1428 • 1 \%, $9.8 \times$ $13.9 \mathrm{~mm}$; DONGSHA 2014, stn CP4128, Dongsha Is $20^{\circ} 44.857^{\prime} \mathrm{N}, 116^{\circ} 08.01^{\prime} \mathrm{E}$; 420-444 $\mathrm{m}$ depth; 1.V.2014; ZRC 2018.1429.

Philippines • 1 o, $8.7 \times 12.4 \mathrm{~mm}$; Bohol, Balicasag I., off Panglao I.; tangle nets of local fishermen; 9 $31^{\prime} 00.2^{\prime \prime} \mathrm{N}, 123^{\circ} 40^{\prime} 50.5^{\prime \prime} \mathrm{E}$; 2-700 m depth;.XII.2000; ZRC 2019.0565 • $2 \mathrm{o}^{7}, 13.6 \times 18.9 \mathrm{~mm}$, $15.0 \times 19.4 \mathrm{~mm}$; same location as ZRC 2019.0565; 200-300 m depth;.I.2004; ZRC 2004.0805 • 1 o', 25-30; same location as ZRC 2019.0565;.VII.2006; ZRC 2019.0567 ex ZRC 2004.0730 (part) $\bullet 4$ o, $11.6 \times 15.6$ to $16.0 \times 22.4 \mathrm{~mm}, 5 \mathrm{o}^{7}, 14.1 \times 20.0 \mathrm{~mm}$ to $15.0 \times 20.9 \mathrm{~mm}$; same location as ZRC $2019.0565 ; 50-500 \mathrm{~m}$ depth; 2.III.2004; ZRC $2004.0727 \bullet 1$ ovigerous + , $15.4 \times$ $21.4 \mathrm{~mm}, 1$ \%, $5 \mathrm{o}^{7}$, largest $17.8 \times 24.5 \mathrm{~mm}$; same location as ZRC 2019.0565; 50-500 m depth; 28.XI.2001; ZRC 2001.0540 - 1 \& , 2 ơ; same location as ZRC 2019.0565; 50-500 m depth; 25-30 July.2006; ZRC 2019.0566, ex ZRC 2001.0845 (part) - 2 9, 2 ơ; same location as ZRC 2019.0565; coll. M. Takeda \& H. Komatsu, II.2003; NSMT-Cr 15365・1 o, $12.8 \times 17.8 \mathrm{~mm}$; PANGLAO 2004, stn P1, tangle nets of local fishermen; $09^{\circ} 36^{\prime}$ S, 12345'E, 90-200 m depth; ZRC 2006.017 • $10^{\circ}, 14.5 \times 20.0 \mathrm{~mm}$; PANGLAO 2004, stn P4, 09'31'00.2”N, 12340'50.5”E, tangle nets of local fishermen; 8.VI.2004; ZRC 2006.0173 • $10^{\circ}$, $25.9 \times 30.1 \mathrm{~mm}$; AURORA 2007, stn CP2709, Luzon Sea; $15^{\circ} 11.07^{\prime} \mathrm{N}, 121^{\circ} 34.72^{\prime} \mathrm{E}-15^{\circ} 12.36^{\prime} \mathrm{N}, 121^{\circ} 34.02^{\prime} \mathrm{E} ; 244-296 \mathrm{~m}$ depth; 28.V.2007; ZRC 2019.0545.

Indonesia. $10^{7}, 6.5 \times 7.9 \mathrm{~mm}$; SJADES, stn CP34, E. Indian Ocean; 0744.464'S, $107^{\circ} 39.018^{\prime} \mathrm{E}$; 234-243 m depth; 29.III.2018; ZRC 2018.1417 .

Diagnosis. - Carapace (Figs 16A, B; 17A, B, E; 27G, H) quadrate, slightly wider than long $(1.4 \times$ wider than long in holotype); slightly convex, marked by two distinct transverse elevations across cardiac, gastric regions. Front (Figs 16H; 17B, C, F) straight, no notch between front, inner edge of supraorbital border (slight notch in some specimens). Rounded, short tooth on outer orbital angle; margin between outer orbital tooth, anterolateral teeth distinctly granular; two slender, acute-tipped anterolateral teeth on each side of carapace, second tooth curved. Large, high granules on subhepatic, pterygostomial regions (Figs 16C; 17B, $\mathrm{C}, \mathrm{F})$, particularly pronounced in pterygostomial crest, ridge; short granules on anterior (sometimes throughout) dorsal surface of carapace. Posterior margin of epistome (Fig. 17B, C, F) straight, notch on each lateral margin absent or slight. Distal fourth of fingers dark brown in females (Fig. 17D, I), males (Fig. 16A, H). "Window" not observed on cheliped propodi. Inner (ventral), distal margin of cheliped carpus (Fig. 16E, F) with acute, curved, triangular tooth typically accompanied by tooth-like tubercles along margin of carpus; outer, proximal margin with short tooth. P2-P5 (Figs 16A; 17D; 27G, H) moderately stout in appearance, P5 barely reaching tip of second anterolateral tooth. Male pleon proportionally narrow (Fig. 16G). G1 (Fig. 24I, K, L-N; Guinot 1989: fig. 37A) slender, subconical, with tapering tip, sometimes elongated; scattered spinules; G2 (Fig. 24J, O; Guinot 1989: fig. 37B) slender, nearly equal or slightly longer than G1, straight flagellum, tip with two lateral spinules.

COLOUR IN LIFE. - Colours of the two photographed individuals (Fig. 27G, H) varies from orange to bright red-orange. Legs (P2-P5) are orange to red-orange with white proximal and distal portions.

Geographical distribution. - Taiwan, South China Sea, Philippines, and Indonesia (southern Java).

Depth. - Present in samples collected at depths of 200-700 m.

\section{REMARKS}

The carapaces of two species (C. polita and C. jugum n. sp.) are distinctive in that the gastric and cardiac regions are distinctively more swollen laterally, so much so that the dorsal surface appears gently corrugated, with a shallow but distinct transverse furrow between the regions (Figs 16A, $\mathrm{B} ; 17 \mathrm{~A}, \mathrm{~B}, \mathrm{E} ; 27 \mathrm{G}, \mathrm{H})$. This is particularly obvious when the surface is dried. While there is also a shallow groove between the gastric and cardiac regions in the other species, the conditions in $C$. polita and C. jugum n. sp. are unusual in that the groove is distinctly wider and more prominent. The chelipeds of these two species are also distinctive in that only the distal third or half of the fingers are pigmented, even in juveniles. Carcinoplax polita is a very distinctive taxon in that it is the only member of this group of species that has an additional spine on the outer surface of the carpus of the cheliped (Fig. 16E). All other species, including C. jugum n. sp., has a smooth and unarmed outer margin. The spine is always present, even if eroded, and occurs even in small specimens and females. In addition to the structure of the cheliped carpal spines, $C$. polita is easily separated from $C$. jugum n. sp. in that the margins between the outer orbital tooth and the anterolateral teeth are distinctly granular (Fig. 17F) (margins appear smooth in C. jugum n. sp.; Fig. 21C); the dorsal surface of the carapace is gently convex in frontal view (Figs 16C; 17B, F) (more prominently inflated in C. jugum n. sp.; Figs 21C; 22C); the posterior margin of the epistome with a prominent triangular median lobe and strongly concave lateral margins (Fig. 17B, C, F) (median lobe more obtuse, lower and the lateral margins distinctively v-shaped in C. jugum n. sp.; Figs 21D; 22D); possessing a proportionally wider male pleon (Fig. 16G) than in C. jugum n. sp. (Fig. 21H), and most significantly, the G1 has the distal part subconical in form with the tip tapering, sometimes elongated, and directed obliquely laterally (Fig. 24I, K, L-N) (the distal part is more dilated, resembling a bird's head with the tip never elongated and directed upwards in C. jugum n. sp.; Fig. 25Q-S). 

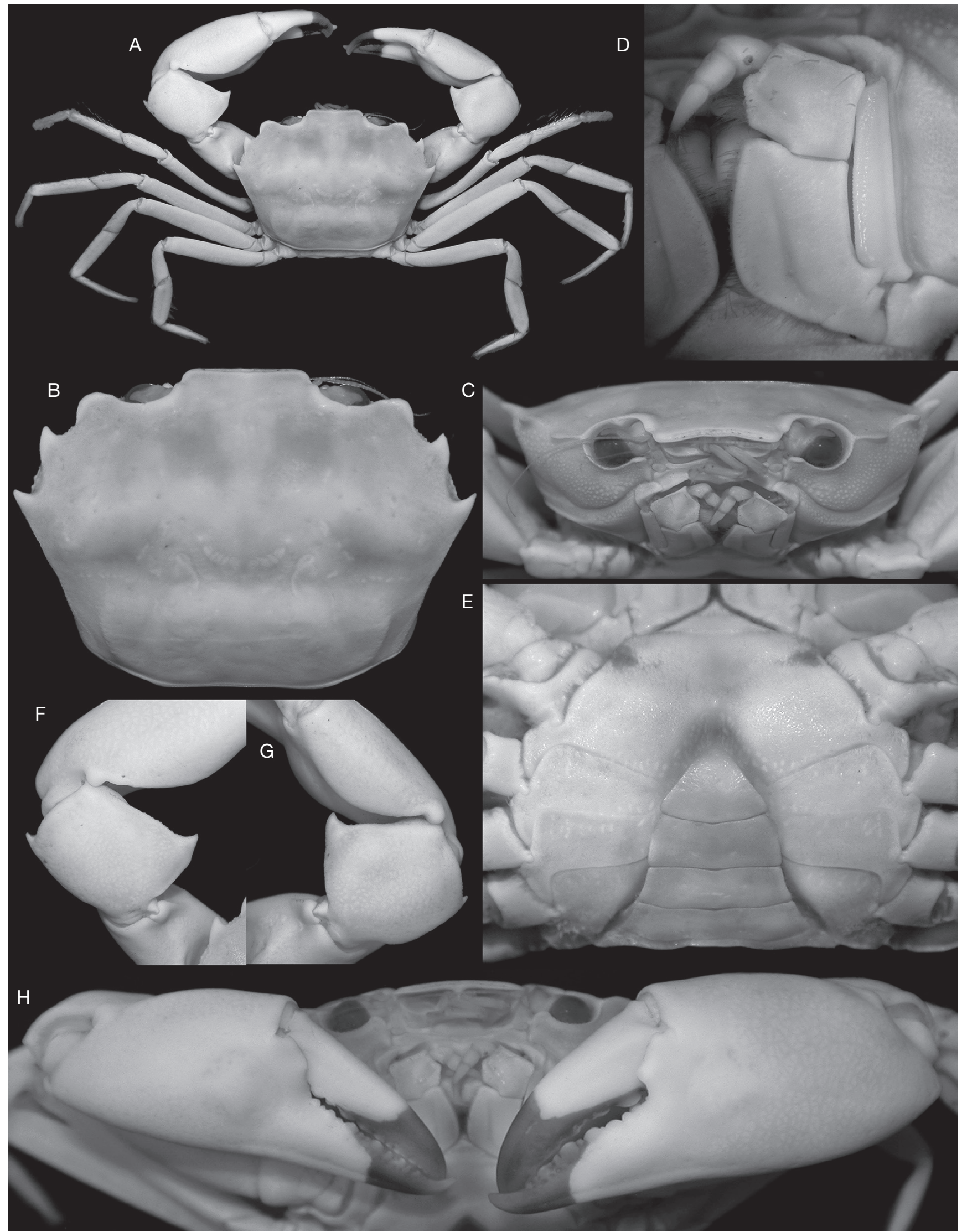

FIG. 16. - Carcinoplax polita Guinot, 1989, ơ $(15.7 \times 22.4 \mathrm{~mm})(\mathrm{ZRC} 2004.0727)$, Philippines: A, overall habitus; B, dorsal view of carapace; C, frontal view of cephalothorax; D, left third maxilliped; $\mathbf{E}$, thoracic sternum and pleon; $\mathbf{F}$, dorsal view of carpus of left cheliped; $\mathbf{G}$, dorsal view of carpus of right cheliped; $\mathbf{H}$, outer view of chelae. 


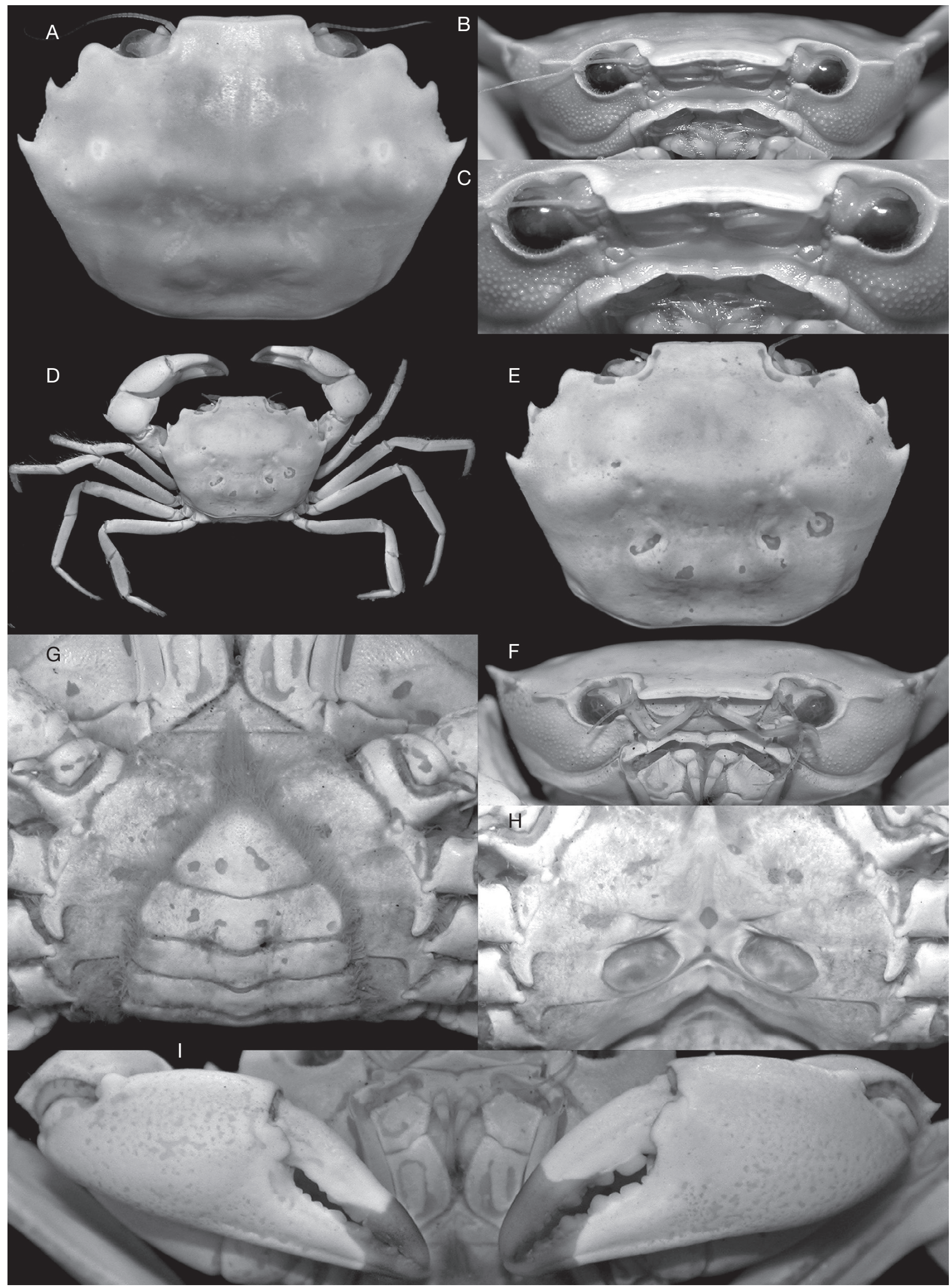

FIG. 17. - Carcinoplax polita Guinot, 1989: A-C, ơ (15.2 × 20.5 mm) (ZRC 2004.0727), Philippines; D-I, o $(15.3 \times 21.1 \mathrm{~mm})($ ZRC 2004.0727), Philippines; A, E, dorsal view of carapace; B, F, frontal view of cephalothorax; C, posterior margin of epistome; D, overall habitus; $\mathbf{G}$, thoracic sternum and pleon; $\mathbf{H}$, sternopleonal cavity and vulvae; $\mathbf{I}$, outer view of chelae. 
Small but adult specimens of $C$. polita (15-18 mm CL), including the holotype, have a G1 which is gently sinuous, with the distal part subconical in form and the tip tapering but short (Fig. 24I, K). In a very large specimen of $C$. polita $(25.9 \times 30.1 \mathrm{~mm}, \mathrm{ZRC} 2019.0545)$, the overall G1 is proportionately more slender than in smaller specimens, with the tip of the distal part prominently more elongated (Fig. 24L$\mathrm{N})$. This specimen, however, agrees in all other aspects with typical C. polita, although that it has relatively larger granules on the carapace surface. These differences are likely to be associated with its large size.

\section{Carcinoplax fasciata $\mathrm{Ng} \&$ Kumar, 2016} (Figs 18; 25J-P)

?Carcinoplax specularis [part] - Castro 2007: 641 [Maldives].

Carcinoplax fasciata Ng \& Kumar, 2016: 193, figs 1-4 [type locality: Kerala, India].

Type MATERial. - Holotype. Arabian Sea • o , $25.8 \times 19.3$ mm, DABFUK, India.

TyPe LOCALITY. — Arabian Sea, off Kerala, India.

Material eXAmined. - India. Holotype ơ, $25.8 \times 19.3 \mathrm{~mm}$; Arabian Sea, Neendakara fishing port, Kerala, southwestern India; $8^{\circ} 38$, N 76¹ $16^{\prime} \mathrm{E}$; 450-500 m depth; coll. B. Kumar, from trawler, 27.XI.2015; DABFUK.

Diagnosis (holotype male, females unKNown). - Carapace (Fig. 18A, B) quadrate, slightly wider than long $(1.3 \times$ wider than long in holotype); slightly convex, smooth. Front (Fig. 18C, D) straight, notch between front, inner edge of supraorbital border absent. Slightly pointed, short tooth on outer orbital angle preceded by low protuberance near orbit; two slender, acute-tipped anterolateral teeth on each side of carapace, first slightly curved. Conspicuous granules on subhepatic, pterygostomial regions (Fig. 18C, D), becoming more pronounced in pterygostomial crest, ridge; short granules on anterior. Posterior margin of epistome (Fig. 18C, D) sinuous, with median salient tip, lateral margins wide, strongly concave. Distal third of fingers pale brown (Figs 21A, I, J; 28G). "Window" not observed on cheliped propodi. Inner (ventral), distal margin of cheliped carpus (Fig. 18G, H) with long, acute tooth. P2-P5 (Fig. 18A, 28G) moderately short in appearance, P5 just reaching base of second anterolateral tooth. Male pleon (Fig. 18E) proportionally narrow. G1 (Fig. 25J-L) slender, straight; slightly pointed tip with scattered spinules, distal end slightly distended; G2 (Fig. 25M-P) slender, slightly longer than G1, slightly curved flagellum, tip weakly birufcated, sharp.

COLOUR IN LIFE. — "Dorsal surfaces of carapace and chelipeds bright orange; tips of anterolateral teeth and cheliped carpal spine white; fingers of chelipeds mostly white except for orange base, distal third light brown; ambulatory legs with dorsal surfaces mostly orange except for white patches on propodus, ventral surfaces paler; prominent red band present that stretches from ventrum of posterolateral carapace margin to below frontal margin; rest of ventral surfaces pinkish-white." (Ng \& Kumar 2016: 197) (Fig. 28G).

GeOgRAPHiCAL Distribution. — Western India.

DЕРTH. - 450-500 m.

\section{REMARKS}

Carcinoplax fasciata is unusual among the species treated here in that its life coloration is distinctive. The front has a prominent red band below it and the fingers of the cheliped are not pigmented black, with only the distal part light brown (Fig. 28G). The condition of the fingers is most like C. polita and C. jugum n. sp., although in these species, the distal parts of the fingers are black or dark brown (Figs 16H; 17I; 21I, J; 22I, J), not pale brown. The life coloration of C. jugum n. sp., unfortunately, is not known. The posterior margin of the epistome of C. fasciata (Fig. 18C, D) most closely resembles that of C. jugum n. sp. with the median part salient and the lateral margins wide and prominently concave (Figs 21C, D). The dorsal carapace features of $C$. fasciata are, however, very different, being evenly convex (Fig. 18A, B); in C. jugum n. sp. (and C. polita) the gastric and cardiac regions are distinctively swollen laterally and the surface appears gently corrugated with a distinct transverse furrow between the regions (Figs 16A, B; 17A, B, E; 27G, $\mathrm{H})$. The $\mathrm{G} 1$ of $C$. fasciata is distinct among the species treated here in that it is relatively straight with the structure gradually tapering from the broad base (Fig. 25J), although the distal part (Fig. 25K, L) resembles those of C. abyssicola, C. longipes, and C. verdensis (Fig. 23B, C, F, G, J, K; 24B, C).

Carcinoplax adelphia $\mathrm{n}$. sp. (Figs 19A-H; 20A-I; 25F-I; 27E, F)

urn:Isid:zoobank.org:act:4AA2E938-5F47-4B42-8BCC-83A2CD1D8E18

TYPe MATERIAL. - Holotype. Vanuatu • o ${ }^{\star}, 19.4 \times 25.4 \mathrm{~mm}$; Vanuatu; MNHN-IU-2016-8002.

Paratypes. Vanuatu $\bullet 2$ \%, largest $16.9 \times 22.4 \mathrm{~mm}$; SANTO 2006, stn AT19, S. Urelapa I.; $15^{\circ} 41^{\prime} S, 1^{\circ} 07^{\circ}$ 'E; 503-600 m depth; 21.IX.2006, ZRC 2009.0997 • 1 ovigerous $9,14.4 \times$ $19.0 \mathrm{~mm}$; SANTO 2006, stn AT96, Big Bay, Santo; $15^{\circ} 06.9^{\prime} \mathrm{S}$, $166^{\circ} 52.8^{\prime} \mathrm{E}$; 328-354 m depth; 14.X.2006; ZRC 2018.1412 - 1 o, $16.9 \times 22.4 \mathrm{~mm}, 1$ ơ, $15.7 \times 21.2 \mathrm{~mm}$; SANTO 2006, stn AT98, Big Bay; $15^{\circ} 06.6^{\prime} \mathrm{S}, 166^{\circ} 50.6^{\prime} \mathrm{E}$; 347-394 $\mathrm{m}$ depth; 14.X.2006; ZRC 2009.0922 • 5 o , $16.5 \times 22.5$ mm, $20^{\star}$, larger one cl $12.3 \mathrm{~mm}$, damaged; same data as ZRC 2009.0922; ZRC $2009.0998 \bullet 10^{\text {"n }}, 18.8 \times 29.9 \mathrm{~mm}$; SANTO 2006, stn AT99, Big Bay; $15^{\circ} 05.5^{\prime} \mathrm{S}, 166^{\circ} 50.9^{\prime} \mathrm{E}$; 351-395 m depth; 14.X.2006; ZRC $2008.0907 \bullet 10$ o , largest $13.6 \times 18.3 \mathrm{~mm}, 15.9 \times 20.8 \mathrm{~mm}$, $1 \mathrm{o}^{7}, 16.0 \times 22.9 \mathrm{~mm}$; same data as ZRC 2008.0907; ZRC $2009.0996 \cdot 1$ ovigerous $9,17.7 \times 24.2 \mathrm{~mm}$; same data as ZRC 2008.0907; ZRC 2018.1413• 3 o, largest $15.1 \times 19.3 \mathrm{~mm}, 14$ o'; SANTO 2006, stn AT100, Big Bay; $15^{\circ} 06.0^{\prime}$ 'S, $166^{\circ} 51.4^{\prime} \mathrm{E}$; 399-416 m depth; 14.X.2006; MNHN-IU-2016-8002 1 ovigerous 9 , $8.5 \times 11.2 \mathrm{~mm}, 10^{7}, 7.6 \times 11.2 \mathrm{~mm}$; SANTO 2006, stn AT121, W Malo I.; $15^{\circ} 38.7^{\prime}$ S, $167^{\circ} 01.2^{\prime} \mathrm{E} ; 275-290 \mathrm{~m}$ depth; 19.X.2006, ZRC 2009.0989・1 0", trap 3, no other data, MNHN-IU-2010-5546.

TYPe LOCALITY. - Vanuatu, SANTO 2006; stn AT100, Big Bay; $15^{\circ} 06.0^{\prime} \mathrm{S}, 166^{\circ} 51.4^{\prime} \mathrm{E} ; 399-416 \mathrm{~m}$ depth. 


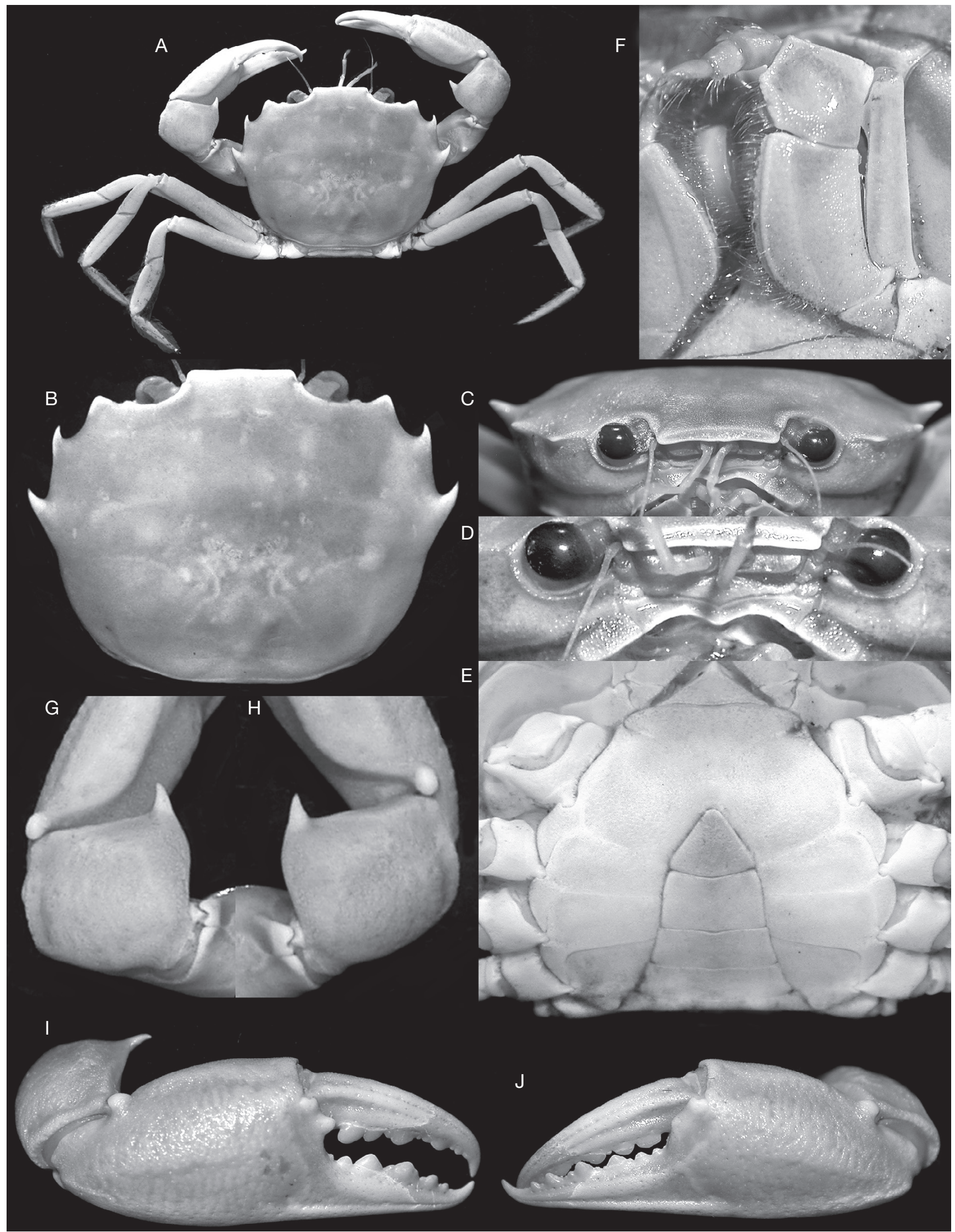

FIG. 18. - Carcinoplax fasciata $\mathrm{Ng} \&$ Kumar, 2016, holotype ơ $(25.8 \times 19.3 \mathrm{~mm}$ ) (DABFUK), India: A, overall habitus; B, dorsal view of carapace; C, frontal view of cephalothorax; D, posterior margin of epistome; $\mathbf{E}$, thoracic sternum and pleon; $\mathbf{F}$, left third maxilliped; $\mathbf{G}$, dorsal view of carpus of left cheliped; $\mathbf{H}$, dorsal view of carpus of right cheliped; I, outer view of right chela; J, outer view of left chela. 


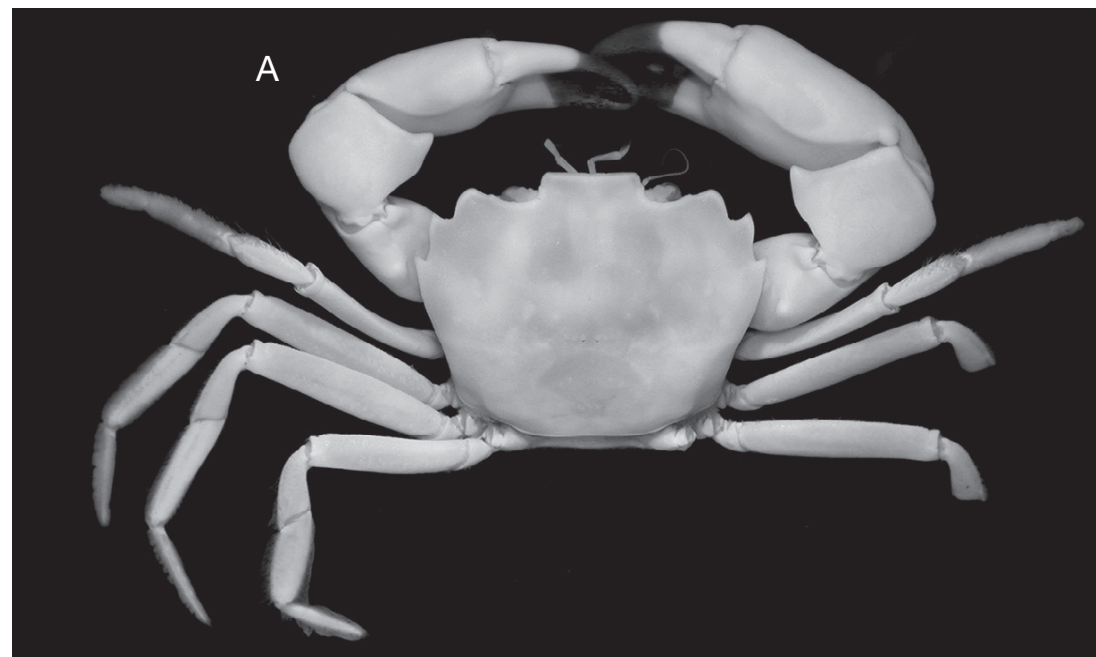

$\mathrm{E}$
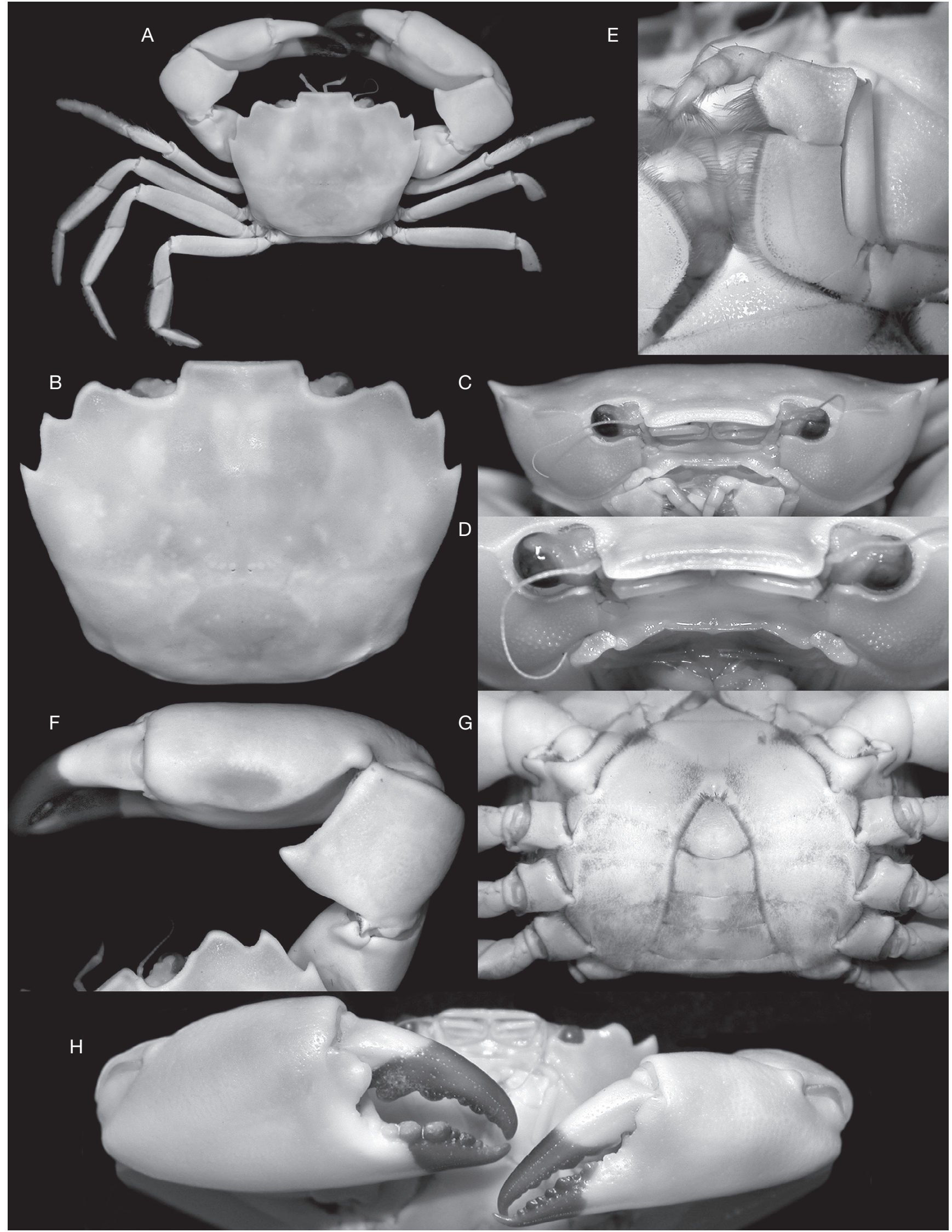

FIG. 19. - Carcinoplax adelphia n. sp., holotype o (19.4 × $25.4 \mathrm{~mm})(\mathrm{MNHN}-\mathrm{IU}-2016-8002)$, Vanuatu: A, overall habitus; B, dorsal view of carapace; C, frontal view of cephalothorax; D, posterior margin of epistome; E, left third maxilliped; F, dorsal view of right cheliped; $\mathbf{G}$, thoracic sternum and pleon; $\mathbf{H}$, outer view of chelae. 


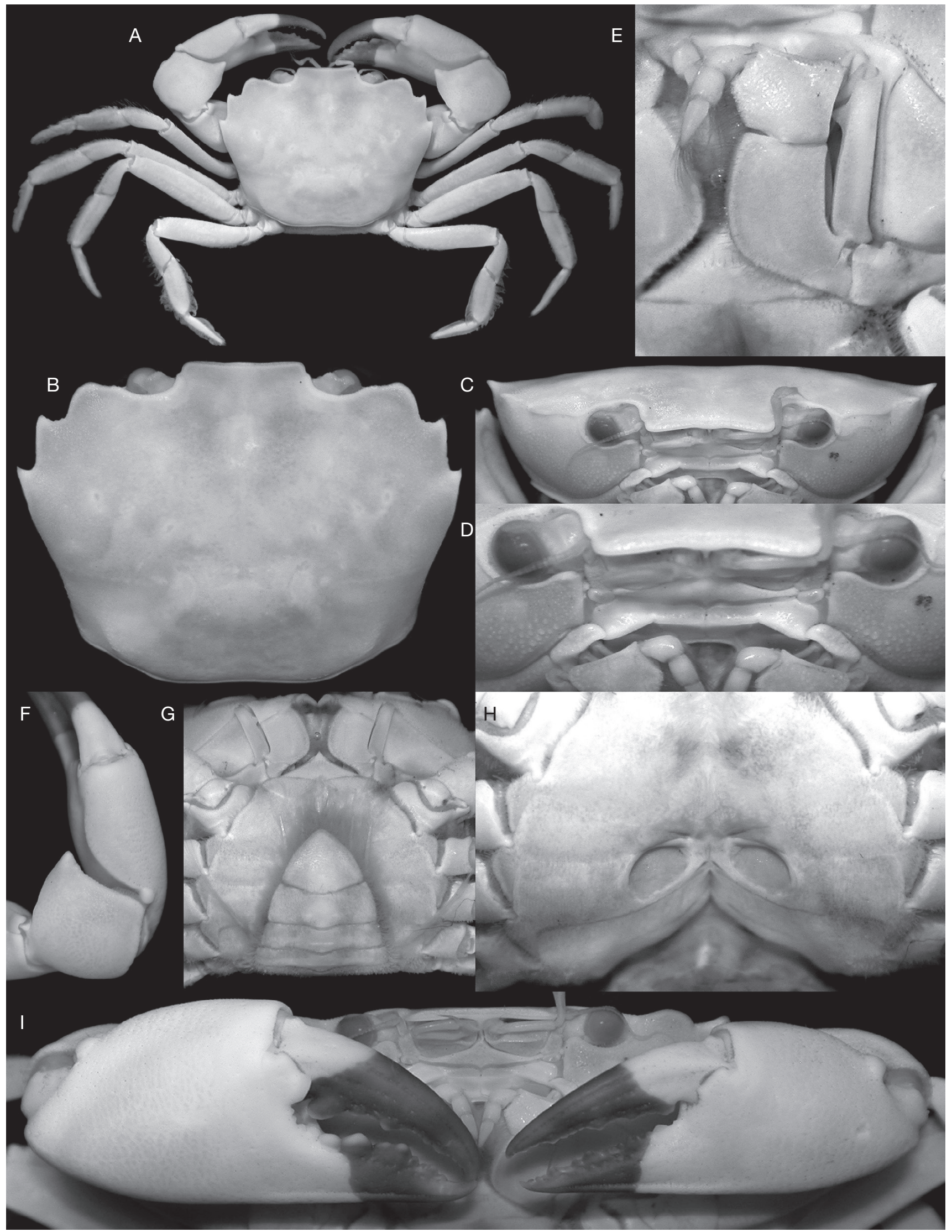

FIG. 20. - Carcinoplax adelphia n. sp., paratype $९(16.9 \times 22.4 \mathrm{~mm})$ (ZRC 2009.0992), Vanuatu: A, overall habitus; B, dorsal view of carapace; C, frontal view of cephalothorax; D, posterior margin of epistome; $\mathbf{E}$, left third maxilliped; $\mathbf{F}$, dorsal view of carpus of right cheliped; $\mathbf{G}$, thoracic sternum and pleon; $\mathbf{H}$, sternopleonal cavity and vulvae; I, outer view of chelae. 
DiagnOSIS. - Carapace (Figs 19A, B; 20A, B; 27E, F) quadrate, slightly wider than long $(1.4 \times$ wider than long in holotype); slightly convex, smooth. Front (Figs 19C, D; 20C, D) straight, slight notch between front, inner edge of supraorbital border. Rounded, short tooth on outer orbital angle; two slender, acutetipped anterolateral teeth on each side of carapace. Conspicuous granules on subhepatic, pterygostomial regions (Figs 19C, D; 20C, D), becoming more pronounced in pterygostomial crest, ridge; short granules on anterior, dorsal surface of carapace. Posterior margin of epistome (Figs 19D; 20D) straight, slight notch on each lateral margin. Distal $2 / 3$ to half of fingers dark brown in females (Fig. 20A, F, I), males (Fig. 19A, F, H). Smooth, oblong "window" on inner, dorsal surface of cheliped propodi of some males (Fig. 19F). Inner (ventral), distal margin of cheliped carpus (Figs 19F; 20F) with triangular tooth. P2-P5 (Figs 19A; 20A; 27E, F) moderately stout in appearance, P5 not reaching second anterolateral tooth. Male pleon (Fig. 19G) proportionally narrow. G1 (Fig. 25F-H) slender; pointed tip with scattered spinules; G2 (Fig. 25I) slender, nearly equal or slightly longer than G1, slightly curved flagellum, tip with two lateral spinules.

ETymology. - The name is derived from the Greek adelphos for 'brother' or 'sister,' alluding to the close affinities of the new species with $C$. specularis. The name is treated as a noun.

COLOUR IN LIFE. - Orange with a semi-circular row of small white spots on each side of the carapace (Fig. 27E, F).

GEOGRAPHICAL DiSTRIBUTION. — Vanuatu.

DEPTH. - Present in samples collected at depths of 275-600 m.

\section{REMARKS}

Carcinoplax adelphia n. sp. and C. specularis are superficially very similar, including the spots on the dorsal surface of the carapace shown in life (Fig. 27E, F for C. adelphia n. sp.; Fig. 27D for C. specularis). They are, however, easily separated by the structure of their G1s. The G1 is relatively shorter and stouter in $C$. specularis (Fig. 25A, B, ) than in C. adelphia n. sp., which is more elongated, particularly the distinctly more slender distal half (Fig. 25F).

Carcinoplax specularis can be also separated from allied species by the obtusely triangular median part of the posterior margin of its epistome, which extends beyond the lateral margins, with the lateral margins gently concave (Figs 10D; 11D; 12D) (median part very low and almost at the same level as the lateral margins, which are almost straight in C. adelphia n. sp.; Figs 19D; 20D). Both share a similar colour pattern, with two unique semi-circular rows of white spots on the dorsal surface of the carapace of live individuals (Fig. 27D for C. specularis; Fig. 27E, F for C. adelphia n. sp.).

Like in C. specularis, a "window" on the chela was found in a few large males of $C$. adelphia n. sp.: $15.7 \times 21.2 \mathrm{~mm}$ (ZRC 2009.0922), $18.8 \times 29.9 \mathrm{~mm}$ (ZRC 2008.0907) and the holotype $19.4 \times 25.4 \mathrm{~mm}(\mathrm{MNHN}-\mathrm{IU}-2016-8002)$. These are not obvious in females or juveniles.
Carcinoplax jugum n. sp.

(Figs 21A-I; 22A-J; 25Q-T)

urn:Isid:zoobank.org:act:AF26AE84-ADE8-4F9A-9A41-BA26DEAFE781

Type material. - Holotype. Philippines • $0^{\star}, 45.5 \times 33.6$ mm; Philippines; ZRC 2004.0777.

Paratypes. Philippines • 1 \%, $25.7 \times 33.8 \mathrm{~mm}$; Bohol, Balicasag I., off Panglao I., tangle nets of local fishermen; $09^{\circ} 31^{\prime} 00.2^{\prime} \mathrm{N}$, $123^{\circ} 40^{\prime} 50.5^{\prime \prime} \mathrm{E}$; 28.XI.2001; ZRC 2001.0528 • 1 o', $24.2 \times$ $32.8 \mathrm{~mm}$; same location as ZRC 2002.0528; 50-500 m depth; ZRC $2001.0973 \cdot 3$ o , $23.3 \times 31.4 \mathrm{~mm}, 24.9 \times 33.4 \mathrm{~mm}, 27.0$ $\times 35.7 \mathrm{~mm}, 3 \mathrm{o}^{\prime \prime}, 13.8 \times 19.6 \mathrm{~mm}, 13.9 \times 19.9 \mathrm{~mm}, 17.2 \times$ $22.2 \mathrm{~mm}$; same location as ZRC 2002.0528; 25-30.VII.2003; ZRC $2004.0750 \bullet 1$ o, 4 o", largest $35.9 \times 48.4 \mathrm{~mm}$, smallest $13.6 \times 18.9 \mathrm{~mm}$; same location as ZRC 2002.0528; 25-30. VII.2006; ZRC 2001.0845 • 2 ㅇ, $23.9 \times 30.5,26.8 \times 35.3 \mathrm{~mm}$; same location as ZRC 2002.0528; ZRC 2004.0730 • 6 \% largest $31.7 \times 41.4 \mathrm{~mm}$; same location as ZRC 2002.0528; 200-300 m depth; ZRC 2002.0655 • 1 o, $25.1 \times 32.5 \mathrm{~mm}$; PANGLAO 2005, stn CP2343, off Pamilican I.; 09 $27.4^{\prime} \mathrm{N}$, $123^{\circ} 49.4^{\prime} \mathrm{E} ; 273-356 \mathrm{~m}$ depth; 23.V.2005; ZRC 2006.0217 - 2 o", $38.5 \times 50.5,41.4 \times 63.0 \mathrm{~mm}$; Maribohoc Bay; coll. J. Arbasto, VII.2004 to.V.2005; ZRC 2018.1432 • 1 \%, $26.8 \times$ $35.2 \mathrm{~mm}, 1$ juvenile \%, $11.0 \times 14.2 \mathrm{~mm}$; PANGLAO 2005, stn CP2359, Bohol Sea; 08 49.9'N, 12334.9'E; 437-476 m depth; 26.V.2005; ZRC 2018.1433 • 1 juvenile . $13.8 \times 18.0 \mathrm{~mm}$; PANGLAO 2005: stn CP2406, Maribohoc Bay, 940.6’ N, 12346.8'E; 334-387 $\mathrm{m}$ depth; 1.VI.2005; ZRC 2018.1434 - 1 \&, $30.0 \times 40.2 \mathrm{~mm}, 1 \mathrm{o}^{*}, 23.7 \times 31.4 \mathrm{~mm}$; PANGLAO 2005, stn PN1, tangle nets; $09^{\circ} 31^{\prime} 00.2^{\prime}$ N, $123^{\circ} 40^{\prime} 50.5^{\prime} \mathrm{E}$; 29.V.2004; ZRC 2004.0777.

TyPe LOCALITY. - Philippines, Bohol, Balicasag I., off Panglao I.; PANGLAO 2004, stn P4, tangle nets of local fishermen.

Diagnosis. - Carapace (Figs 21A, B; 22A, B) quadrate, slightly wider than long $(1.3 \times$ wider than long in holotype); slightly convex, marked by two distinct transverse elevations across cardiac, gastric regions. Front (Figs $21 \mathrm{C}, \mathrm{D} ; 22 \mathrm{C}, \mathrm{D})$ slightly sinuous, slight oblique notch between front, inner edge of supraorbital border. Conspicuous, salient ocular margins, subocular tooth. Triangular, elevated tooth on outer orbital angle; two slender, acute-tipped anterolateral teeth on each side of carapace. Short granules on subhepatic, pterygostomial regions (Figs 21C, D; 22C, D), becoming more pronounced in pterygostomial crest, ridge. Posterior margin of epistome (Figs 21D; 22D) sinuous, with median salient tip, lateral margins wide, concave. Distal third to half of fingers dark brown in females (Fig. 22I, J), males (21A, I, J). Inner (ventral), distal margin of cheliped carpus (Figs 21F, D; 22F) with long, slender, acute-tipped tooth. P2-P5 long, slender in appearance. Male pleon (Fig. $21 \mathrm{H}$ ) proportionally narrow. G1 (Fig. 25Q-S) slender; conspicuously pointed tip; G2 (Fig. 25T) slender, nearly equal or slightly longer than G1, slightly curved flagellum, tip with two lateral spinules.

ETyMology. - From the Latin jugum for 'yoke'; in reference to the diagnostic yoke-like, wide, and prominently concave lateral margins of the posterior margin of the epistome. Used as a noun in apposition.

COlOUR IN LIFE. — Not known. 


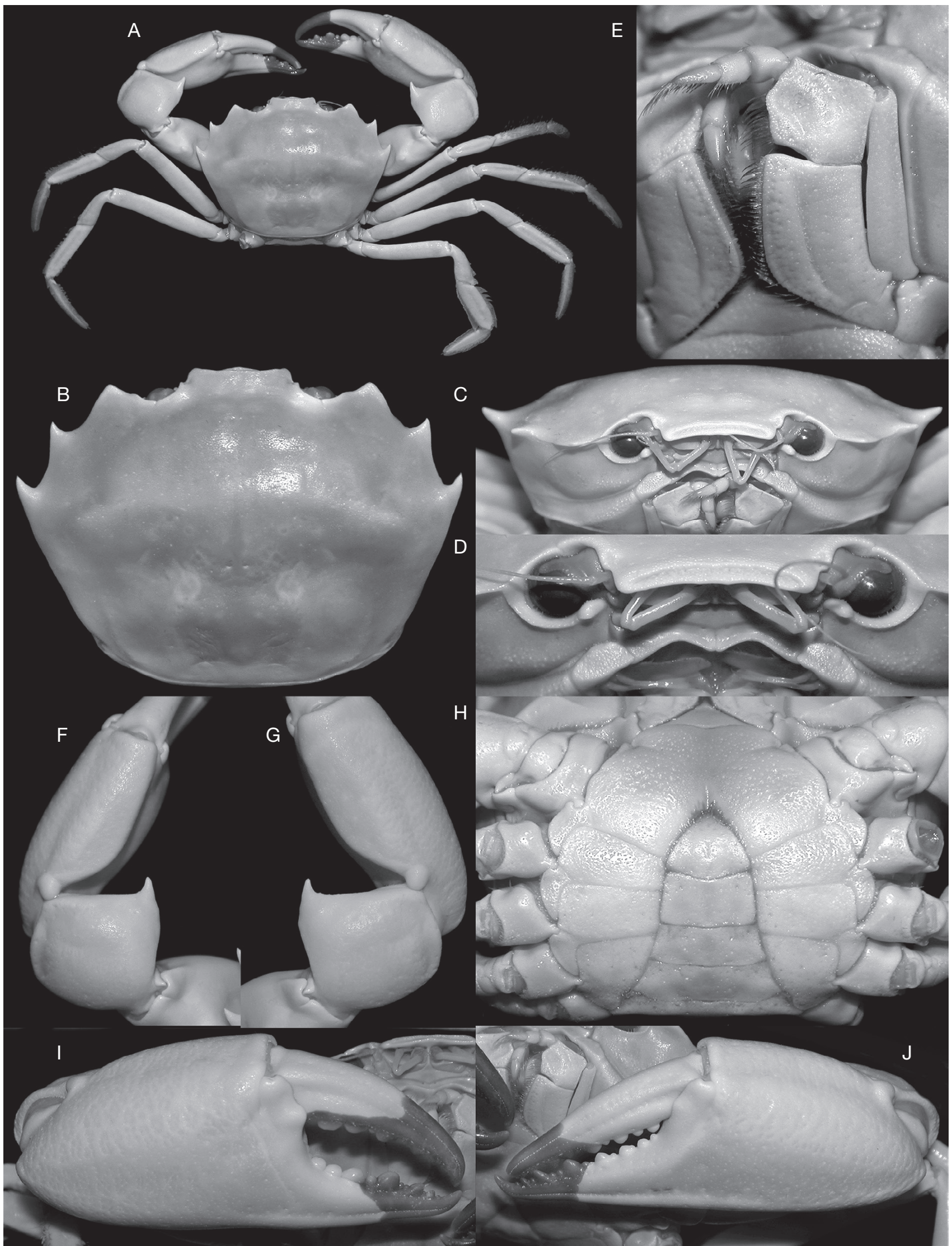

FIG. 21. - Carcinoplax jugum n. sp., holotype ơ $(33.6 \times 45.5 \mathrm{~mm}$ ) (ZRC 2004.0777), Philippines: A, overall habitus; B, dorsal view of carapace; C, frontal view of cephalothorax; D, posterior margin of epistome; $\mathbf{E}$, left third maxilliped; $\mathbf{F}$, dorsal view of carpus of left cheliped; $\mathbf{G}$, dorsal view of carpus of right cheliped; $\mathbf{H}$, thoracic sternum and pleon; I, outer view of right chela; J, outer view of left chela. 


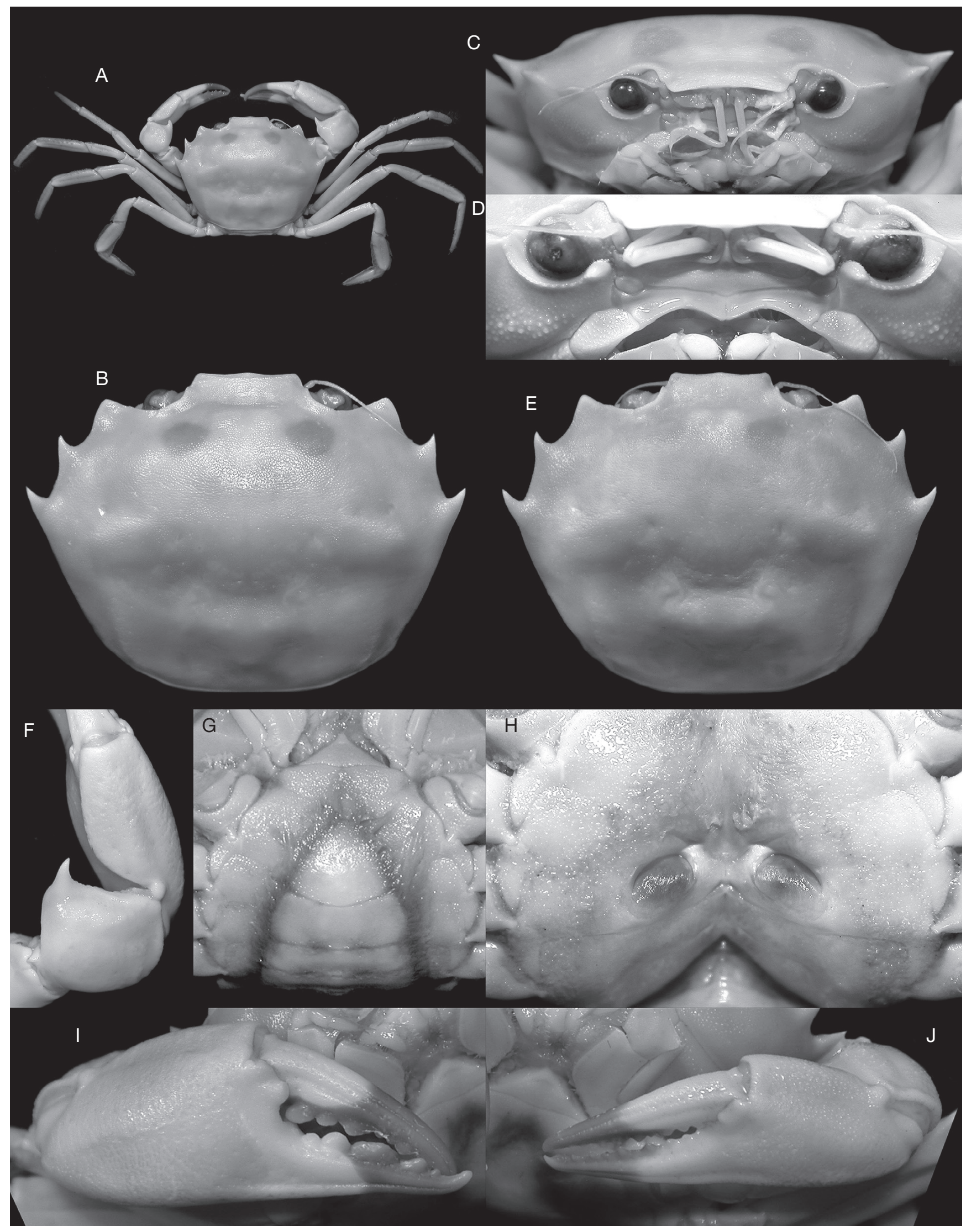

FIG. 22. - Carcinoplax jugum n. sp.: A-C, F-J, paratype $q(25.1 \times 32.5 \mathrm{~mm})($ ZRC 2006.0217), Philippines; D, E, paratype $q(26.9 \times 35.4 \mathrm{~mm})($ ZRC 2018.1431), Philippines: A, overall habitus; B, E, dorsal view of carapace; C, frontal view of cephalothorax; D, posterior margin of epistome; $\mathbf{F}$, dorsal view of carpus of right cheliped; G, thoracic sternum and pleon; H, sternopleonal cavity and vulvae; I, outer view of right chela; J, outer view of left chela. 

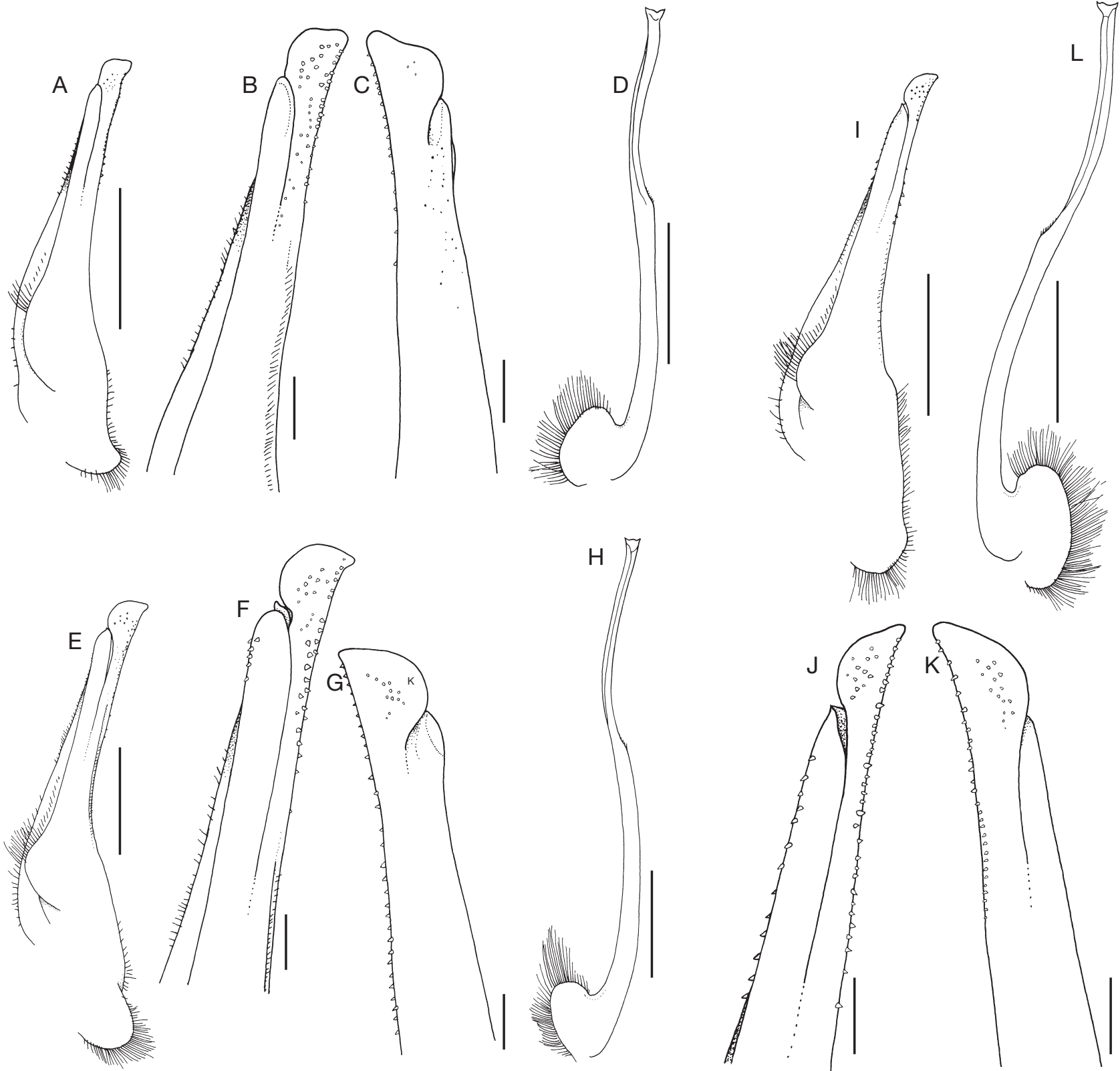

FIG. 23. - Gonopods: A-D, Carcinoplax abyssicola (Miers, 1885), ơ $(8.0 \times 10.4 \mathrm{~mm})(\mathrm{MNHN}-\mathrm{IU}-2014-11535)$, Fiji; E-H, C. abyssicola, ơ (11.0 × 15.5 mm) (MNHN-IU-2014-11529), Fiji; I-L, C. longipes (Wood-Mason, 1891), ơ (9.9 × $13.9 \mathrm{~mm}$ ) (ZRC 2018.1424), Java. A, E, I, left G1 (ventral view); B, F, J, distal part of left G1 (ventral view); C, G, K, distal part of left G1 (dorsal view); D, H, right G2 (left G2 damaged); L, left G2. Scale bars: A, D, E, H, I, L, 1.0 mm; B, C, $\mathrm{F}, \mathrm{G}, \mathrm{J}, \mathrm{K}, 0.2 \mathrm{~mm}$.

Geographical distribution. — Philippines.

DEPTH. - Present in samples collected at depths of approximately 50-500 $\mathrm{m}$ (273-476 $\mathrm{m}$ where depths were more accurately measured).

\section{REMARKS}

See Remarks for C. polita.
It is noteworthy that most of the specimens of $C$. jugum n. sp. collected were obtained from tangle nets set on steep deep-sea cliffs, a habitat which is hard to survey (see $\mathrm{Ng}$ et al. 2009; Mendoza et al. 2010). This probably explains the paucity of specimens of this species from trawled material in earlier expeditions to Philippines. 

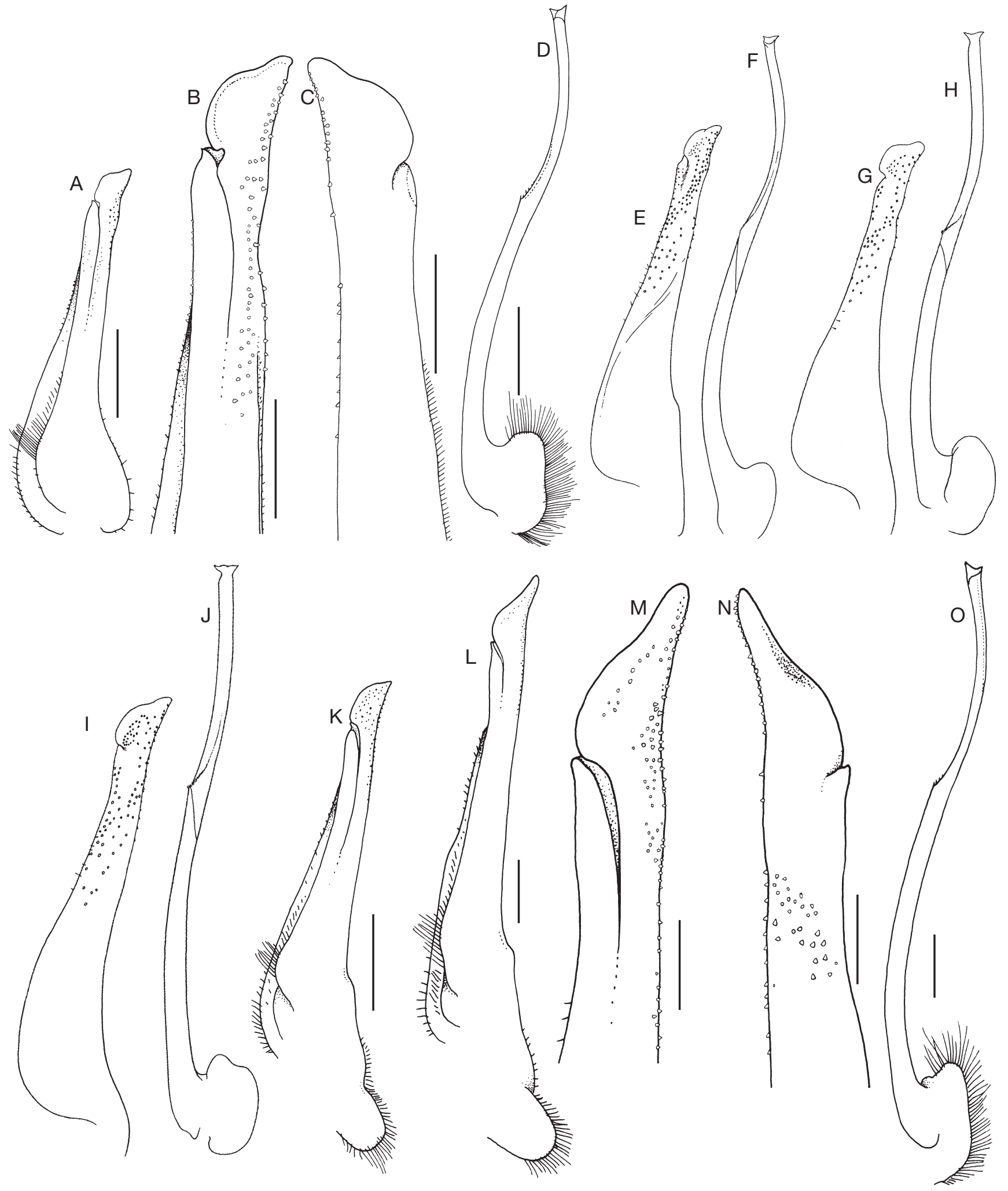

FIG. 24. - Gonopods: A-D, Carcinoplax verdensis Rathbun, 1914, ơ (14.9 × $20.2 \mathrm{~mm})($ ZRC 2019.0547), Philippines; E, F, C. verdensis, ơ (18.0 × 24.4 mm) (MNHN-B10377), Philippines; G, H, C. verdensis, ơ $(13.0 \times 18.0 \mathrm{~mm})($ MNHN-B10264), Philippines; I, J, C. polita Guinot, 1989, holotype ơ $(15.0 \times 19.0$ mm) (MNHN-B10141), Philippines; K, C. polita, ơ (14.5 × 20.0 mm) (ZRC 2000.0173), Philippines; L-O, C. polita, ơ (25.9 × $30.1 \mathrm{~mm})($ ZRC 2019.0545), Philippines. A, K, L, left G1 (ventral view); B, M, distal part of left G1 (ventral view); C, N, distal part of left G1 (dorsal view); E, G, I, right G1 (dorsal view); D, J, O, D, L, H, left G2; F, H, J, right G2. E-H, after Guinot (1989: figs 35A, B; 36A, B) (as C. aff. longipes); I, J, after Guinot (1989: fig. 37A, B). Scale bars: A, D, K, L, O, 1.0 mm; $\mathrm{B}, \mathrm{C}, \mathrm{M}, \mathrm{N}, 0.5 \mathrm{~mm}$; E, F, G, H, not to scale. 


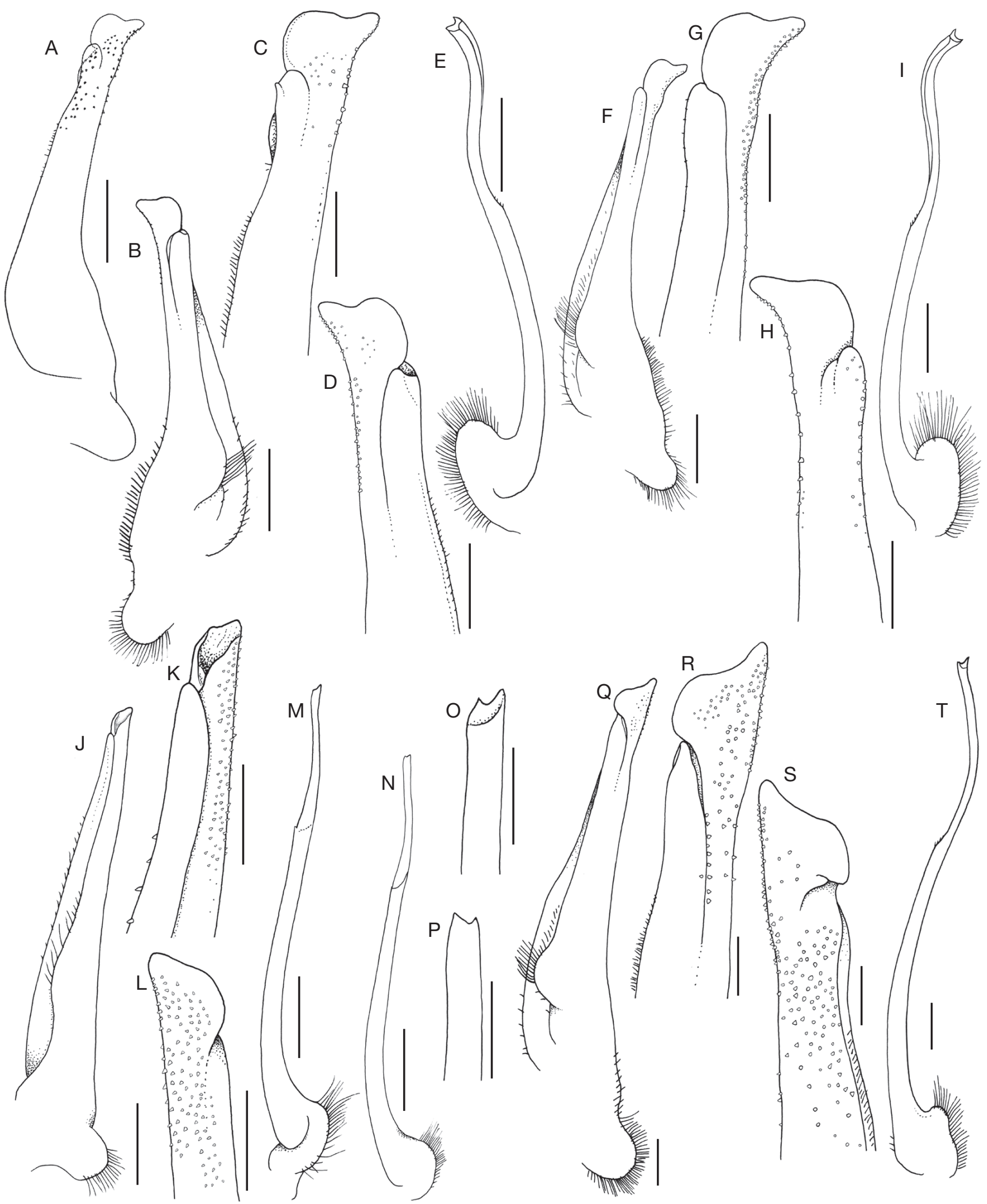

FIG. 25. - Gonopods: A-E, Carcinoplax specularis Rathbun, 1914, holotype ơ $(16.7 \times 23.0 \mathrm{~mm})$ (USNM 46164), Philippines; F-I, C. adelphia n. sp., holotype ơ $(19.4 \times 25.4 \mathrm{~mm})(\mathrm{MNHN}-\mathrm{IU}-2016-8002)$, Vanuatu; J-P, C. fasciata Ng \& Kumar, 2016, holotype ơ $(25.8 \times 19.3 \mathrm{~mm})$ (DABFUK), India; Q-T, C. jugum n. sp. holotype $\sigma^{7}(33.6 \times 45.5 \mathrm{~mm})($ ZRC 2004.0777), Philippines. A, right G1 (dorsal view), B, right g1 (ventral view); C, distal part of right G1 (ventral view); D, distal part of right G1 (dorsal view); E, right G2; F, J, Q, left G1 (ventral view); G, K, R, distal part of left G1 (ventral view); H, L, S, distal part of left G1 (dorsal view); I, M, D, Q, left G2; N, right G2; O, P, distal part of right G2. A, after Guinot (1989: fig. 34A). Scale bars: A, B, E, F, I, J, M, N, Q, T, 1.0 mm; C, D, G, H, K, L, R, S, $0.5 \mathrm{~mm} ; \mathrm{O}, \mathrm{P}, 0.25 \mathrm{~mm}$. 


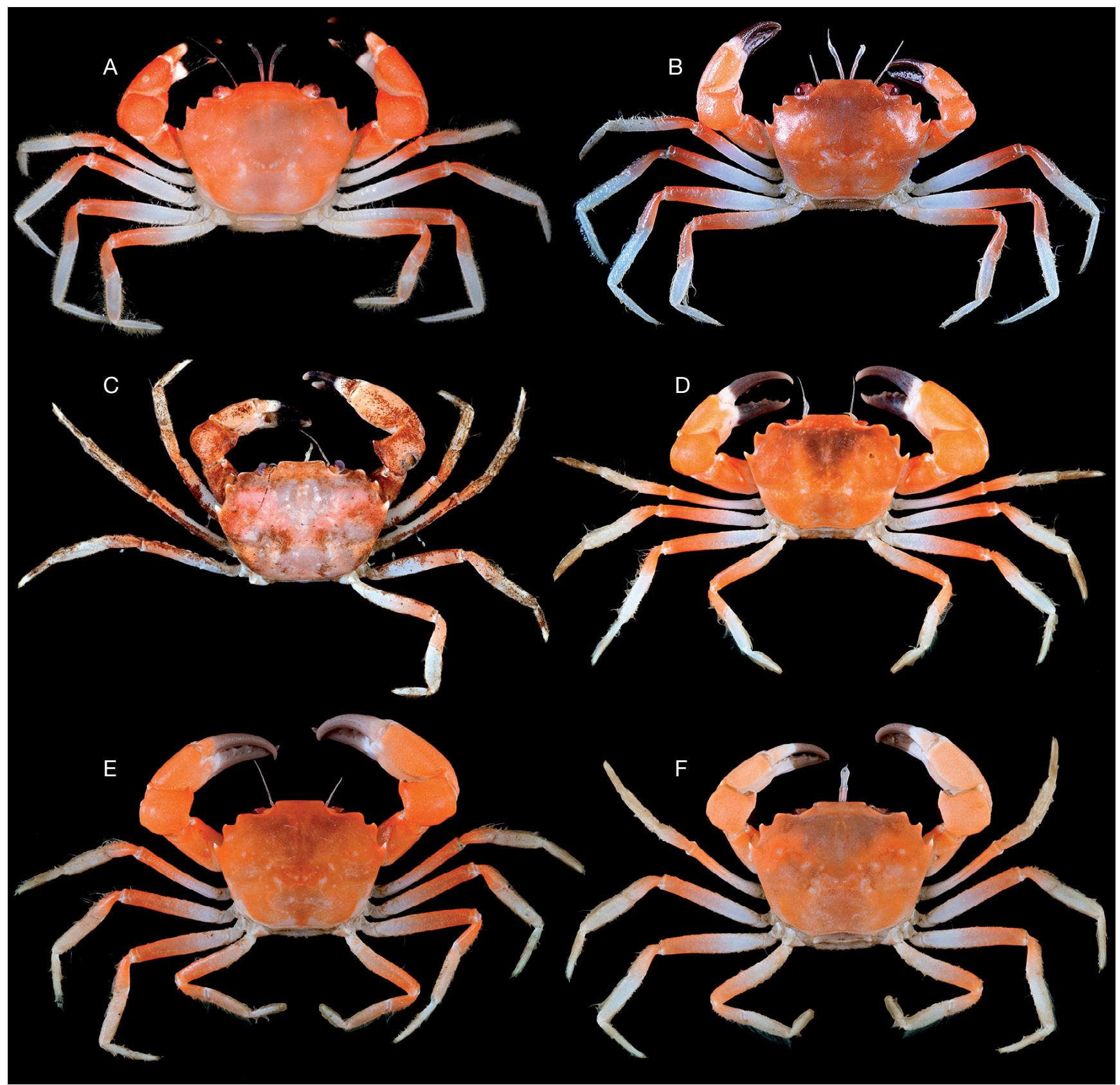

FiG. 26. - Colour in life, Carcinoplax abyssicola (Miers, 1885). A, o (10.4 × $14.6 \mathrm{~mm})$ (ZRC 2008.0970), Vanuatu; B, ơ (8.0 × 10.6 mm) (ZRC 2018.1419), Vanuatu;

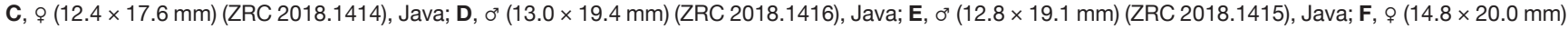
(ZRC 2018.1415), Java. Photographs: SJADES.

Acknowledgements

We thank Laure Corbari and Paula A. Rodríguez-Moreno (MNHN) as well as Tin-Yam Chan (National Taiwan Ocean University) for sending us precious material, as well as photographs of some of the material from several expeditions. We are grateful to Karen Reed and Rafael Lemaitre (USNM) for facilitating the loan of type material, and to Paul Clark (NHM) for kindly helping us search for NHM material. The SJADES cruise was a joint Indonesian-Singapore expedition to southern Java funded by the National University of Singapore (chief scientist PKLN) and the Research Center for Oceanography, Indonesian Institute of Sciences (LIPI) (chief scientist Dwi Listyo Rahayu); and supported by their respective Ministries of Foreign Affairs under the RISING 50 program to promote bilateral co-operation. Thanks are also due to Bertrand Richer de Forges and Tin-Yam Chan for their invaluable help during the cruise. The MNHN specimens were collected during the following deep-sea cruises of the Tropical Deep-Sea Benthos program: SALOMON 1 (https://doi.org/10.17600/1100090); SALOMON 2 (https://doi.org/10.17600/4100090); 

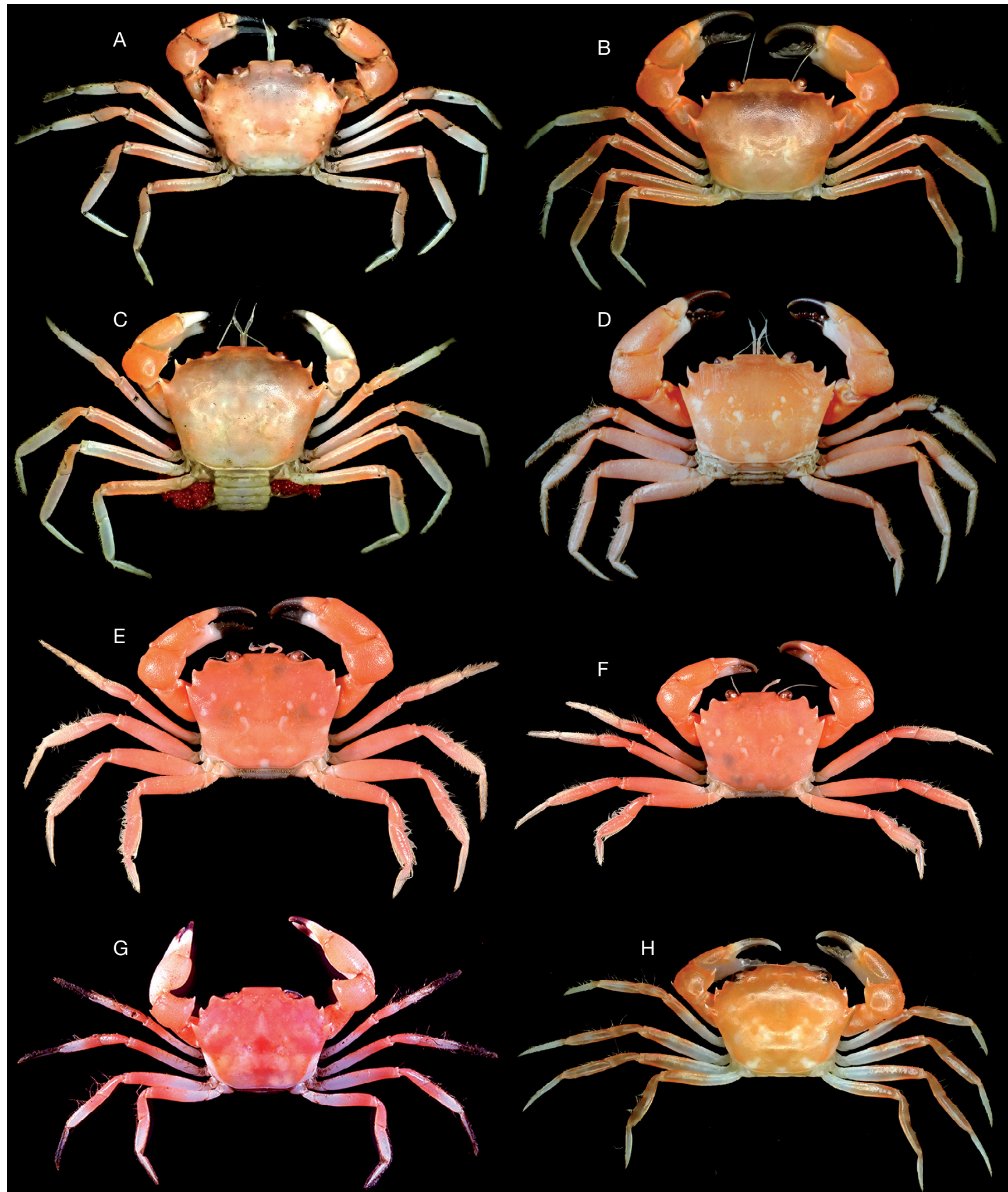

FIG. 27. - Colour in life: A, Carcinoplax longipes (Wood-Mason, 1891), ơ (9.0 × $12.4 \mathrm{~mm})(\mathrm{ZRC} 2018.1422)$, Java; B, C. longipes, ơ (10.8 × 14.4 mm) (ZRC 2018.1427), Java; C, C. longipes, ovigerous o $(10.8 \times 14.3 \mathrm{~mm})($ ZRC 2018.1420), Java; D, C. specularis Rathbun, 1914, ơ (18.4 $\times 25.8 \mathrm{~mm})($ ZRC 2001.0134), Taiwan; E, C. adelphia n. sp., paratype ơ $(15.7 \times 21.2 \mathrm{~mm})$ (ZRC 2009.0922), Vanuatu; F, C. adelphia n. sp., paratype 9 (16.9 × 22.4 mm) (ZRC 2009.0922 (, Vanuatu; G, C. polita Guinot, 1989, o (12.8 × 17.8 mm) (ZRC 2006.0176), Philippines; H, C. polita, ơ $(6.5 \times 7.9$ mm) (ZRC 2018.1417), Java. Photographs: A-C, SJADES; D, P.-H. Ho; E-H, T.-Y. Chan. 


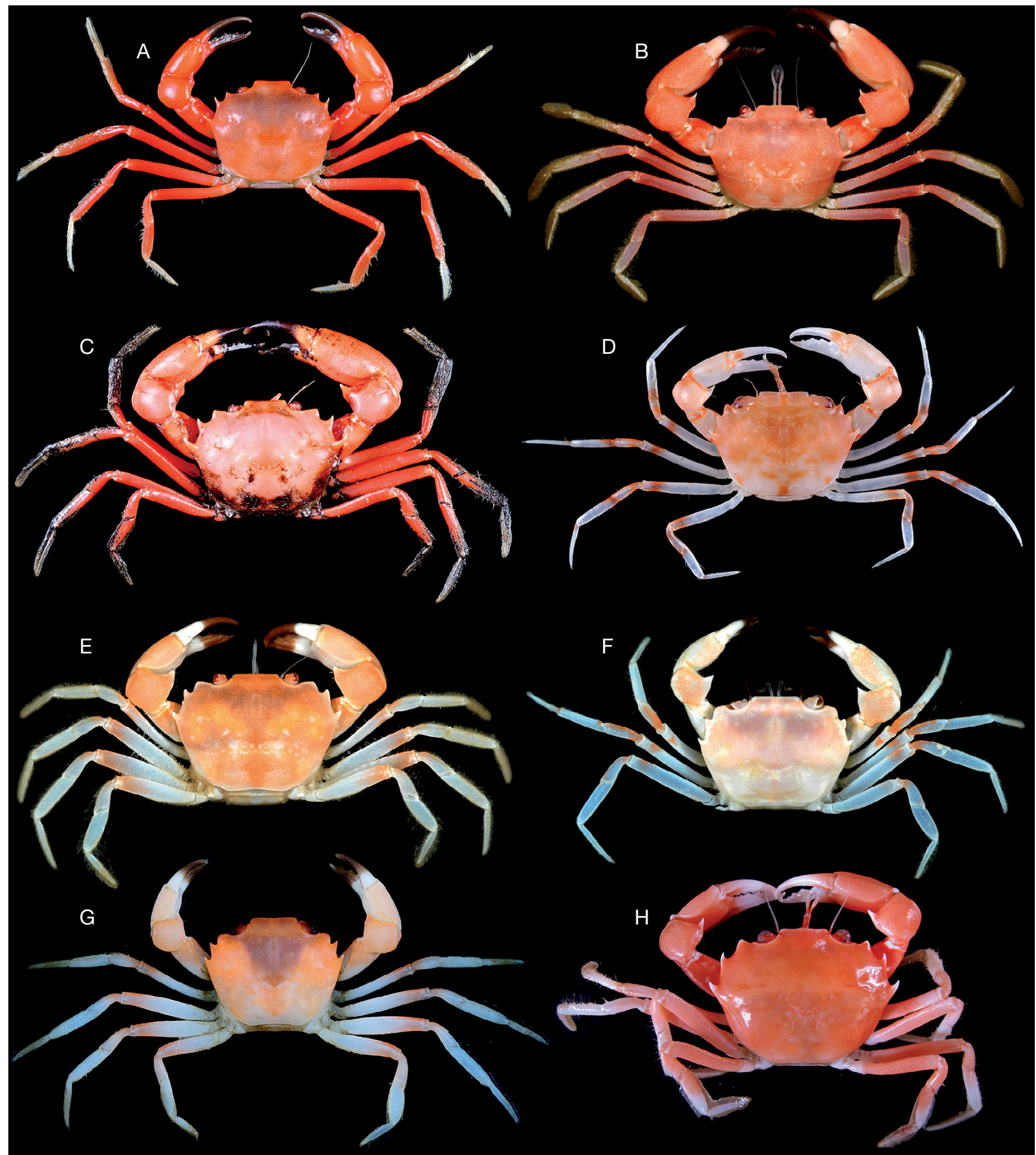

FIG. 28. - Colour in life: A, Carcinoplax verdensis Rathbun, 1914, ơ (16.9 $23.0 \mathrm{~mm})$ (ZRC 2009.1003), Philippines; B, C. verdensis, ơ (15.7 $\times 21.4 \mathrm{~mm})($ ZRC 2019.0549), Philippines; C, C. verdensis, ơ (19.2 × $27.7 \mathrm{~mm})$ (ZRC 2019.0555), Philippines; D, C. verdensis, $\%(5.8 \times 8.1 \mathrm{~mm})($ ZRC 2019.0548), Philippines; E, C. verdensis, o $(12.8 \times 17.9 \mathrm{~mm})$ (ZRC 2019.0559), Philippines; F, C. verdensis, o $(7.9 \times 10.9 \mathrm{~mm})($ ZRC 2019.0560), Philippines; G, 1 \% $(6.8 \times 8.8 \mathrm{~mm})($ ZRC 2019.0374), South China Sea; H, C. fasciata Ng \& Kumar, 2016, holotype ơ $(25.8 \times 19.3$ mm) (DABFUK), India. Photographs: D-G, T.-Y. Chan; H, B. Kumar.

SALOMON BOA 3 (https://doi.org/10.17600/7100070); BOA 0 (https://doi.org/10.17600/4100140); BOA 1 (https://doi.org/10.17600/5100060); SANTO 2006 (https://doi.org/10.17600/6100110); SMIB 6 (https:// doi.org/10.17600/90005911); BATHUS 4 (https:// doi.org/10.17600/94100030); EXBODI (https://doi. org/10.17600/11100080); BORDAU 1 (https://doi. org/10.17600/99100020); BORDAU 2 (https://doi. 


\section{Key to species of Carcinoplax H. Milne Edwards, 1852}

1. One well-developed, anteriorly curved anterolateral tooth posterior to outer orbital tooth on each side of carapace (Guinot 1989: pl. 13, fig. F, as C. eurysternum Guinot \& Richer de Forges, 1981)

C. ischurodous (Stebbing, 1923).

- Two anterolateral teeth posterior to outer orbital angle ( 1 or 2 anterolateral teeth may be greatly reduced or even obsolete in some large individuals)

2. Adults attain large size (cl more than $30-40 \mathrm{~mm}$ ), with reduced outer orbital and anterolateral teeth (obsolete in largest individuals), rounded anterolateral borders (carapace becoming almost spherical), and much enlarged chelipeds (P1) with conspicuously elongated meri, propodi

- Adults do not attain large size (cl less than 30-40 mm), do not show progressive reduction in outer orbital (if present) and anterolateral teeth with corresponding rounded anterolateral borders and chelipeds (P1) with conspicuously elongated meri, propodi

3. Low, conspicuous granules on carapace; small individuals with triangular, acute, curved, acute first and second anterolateral teeth (Guinot 1989: pl. 1, fig. D); uniformly red to dark red-brown carapace in life, bright redbrown markings on chelipeds (P1) C. longimana (De Haan, 1833).

- No conspicuous granules on carapace; small individuals with narrow, acute anterolateral teeth, or small, blunt first anterolateral teeth; in life, carapace not uniformly red or dark-red brown

4. Small- to medium-size individuals with 2 narrow, acute, spine-like anterolateral teeth below acute, conspicuous outer orbital tooth on each side of carapace (Guinot 1989: pl. 1, figs G, H; Hsueh \& Huang 2002: fig. 6A); carapace nearly quadrate, with red, round spot on dorsal surface in most individuals when fresh (Hsueh \& Huang 2002: fig. 8B) C. indica Doflein, 1904.

- Small- to medium-size individuals with blunt first anterolateral tooth, second tooth curved, acute; carapace globose; never with red spot on carapace in life

5. Outer orbital angle with low tooth or absent; second anterolateral tooth short, low (more conspicuous in small individuals), not hook-like

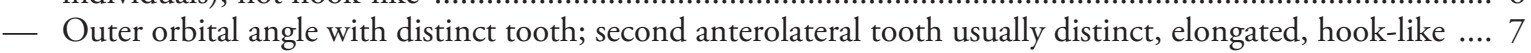

6. P2-P5 relatively short; anterolateral teeth may be low in larger individuals but always visible (Ng \& Mitra 2019: fig. 6C, D); purple-red vertical band across carapace from front to posterior border in life (Hsueh \& Huang 2002: fig. 8C); western Pacific C. purpurea Rathbun, 1914.

- P2-P5 relatively longer; anterolateral tooth short, absent in large individuals (Guinot 1989: fig. 9A-C; pl. 3, figs A, C, E); carapace uniformly colored in life; Red Sea and Persian Gulf C. monodi Guinot, 1989.

7. G1 with rounded, truncated tip (Ng \& Mitra 2019: fig. 8K, L, N); western Pacific ..... C. sinica Chen, 1984.

— G1 with pointed tip ( $\mathrm{Ng} \&$ Mitra 2019: fig. 8E, F); Indian Ocean C. mistio $\mathrm{Ng} \&$ Mitra, 2019.

8. Carapace, chelipeds (P1), and P2-P5 covered with conspicuous short setae

- Carapace, chelipeds (P1), and/or P2-P5 may have sparse setae, short tomentum, or mostly or completely devoid of conspicuous setae, or tomentum

- Conspicuous, acute tubercles on proximal portion of P1 propodi (may be absent in large individuals) (Hsueh \& Huang 2002: fig. 5E); distal quarter of fingers darkly pigmented; acute tooth on distal portion of P2-P5 meri (Chen 1998: fig. 4-2; Hsueh \& Huang 2002: fig. 5C); no conspicuous color pattern in life .....

C. spinosissima Rathbun, 1914.

- Conspicuous, low, blunt tubercles on proximal portion of cheliped (P1) propodi (Guinot 1989: pl. 6, fig. H); distal half of fingers darkly pigmented; distal portion of P2-P5 meri smooth; in life with orange reticulated lines on P1 and carapace (obvious when denuded) C. nana Guinot, 1989.

10. Carapace, chelipeds (P1), and P2-P5 covered with short tomentum (large individuals only on ambulatory legs) (Hsueh \& Huang 2002: fig. 7A) C. tomentosa Sakai, 1969.

- Carapace, chelipeds (P1), and P2-P5 not covered with conspicuous short tomentum

11. Outer orbital angle without tooth or eminence; with 2 thin, spine-like anterolateral teeth (Castro 2007: figs 4A, 5) C. tenuidentata Castro, 2007.

- Outer orbital angle ends in lobe or tooth; anterolateral teeth not thin, spine-like

12. Front with slight median notch (Guinot 1989: fig. 17) C. confragosa Rathbun, 1914.

- Front straight, without distinct median notch. 
13. Conspicuous, well-developed anterolateral teeth, with acute, anteriorly-oriented or hook-like tips ............ 18

— Relatively small, blunt, non-spinous anterolateral teeth (Castro 2007: figs 7, 10) ................................ 24

14. P2-P5 long, relatively slender, distal end of folded P5 merus extending beyond tip of second anterolateral tooth

- P2-P5 short, distal end of folded P5 merus only reaching or barely reaching tip of second anterolateral tooth

15. Two conspicuous, wide transverse ridges on dorsal surface of carapace (Castro 2007: fig. 3); western Pacific ..

- Dorsal surface of carapace evenly convex, without transverse ridges; eastern Indian Ocean C. cracens Castro, 2007. C. longipes (Wood-Mason, 1891).

16. Two conspicuous, wide transverse ridges on dorsal surface of carapace

- Dorsal surface of carapace evenly convex, without conspicuous ridges. C. inaequalis (Yokoya, 1933).

17. All anterolateral teeth anteriorly curved; narrow, J-shaped gap between outer orbital tooth and first anterolateral tooth (Castro 2009: fig. 1A); southwestern and central Pacific ............................ C. uncinata Castro, 2009.

- Anterolateral teeth sharp but not curved (only first one in rare cases); outer orbital angle often prominent, rounded.

18. Posterior margin of epistome with median part pronounced, triangular, lateral margins conspicuously concave (Fig. 21D)

- Posterior margin of epistome with truncated or nearly straight median part; lateral margins nearly straight or slightly sinuous (Fig. 3D)

19. Two transverse elevations across cardiac, gastric regions of carapace (Figs 21C, D; 22C, D); western Pacific ...

- Dorsal surface of carapace evenly smooth, without transverse elevations; western Indian Ocean

20. Outer, proximal margin of cheliped carpus with sharp tooth; western Pacific and eastern Indian Ocean C. polita Guinot, 1989.

- Outer, proximal margin of cheliped carpus smooth, without tooth 21

21. P2-P5 proportionally short, stout, with distal end of folded P5 merus not reaching tip of second anterolateral tooth (e.g. Figs 10A; 11A; 19A; 20A)

- P2-P5 proportionally long, slender, with distal end of folded P5 merus reaching tip of second anterolateral tooth (e.g. Figs 2A; 3A; 13A; 14A)

22. Posterior margin of epistome with median part not protruding (Figs 19D; 20D); G1 elongated, distal half distinctly slender (Fig. 25F); southwestern Pacific C. adelphia n. sp.

- Posterior margin of epistome with median part pronounced, protruding (Figs 10D; 11D; 12D); G1 relatively short, stout (Fig. 25A, B); northwestern Pacific .............................................. C. specularis Rathbun, 1914.

23. Fingers dark brown or black almost along their entire lengths (Figs $2 \mathrm{H} ; 3 \mathrm{I} ; 4 \mathrm{H} ; 5 \mathrm{H}$ ); inner distal angle of carpus of cheliped dentiform (Figs 2E, F; 3F, 4F, 5E); Indian Ocean and southwestern Pacific

C. abyssicola (Miers, 1885).

- Fingers dark brown or black along the distal two-thirds to half portions (Figs 13I, J; 14H); inner distal angle of carpus of cheliped usually spiniform with tip narrow (Figs 13F; 14F; 15E); western Pacific .....

C. verdensis Rathbun, 1914.

24. Outer, dorsal surface of cheliped (P1) propodi and carpi with conspicuous granular tubercles (Castro 2007: fig. 8); P2-P5 relatively short (Fig. 7), distal end of folded P5 merus only reaching tip of second anterolateral tooth; western Pacific ................................................................................... C. tuberosa Castro, 2007.

- Outer, dorsal surface of chelipeds (P1) smooth; P2-P5 proportionally long (Castro 2007: fig. 10), distal end of folded P5 merus extending beyond tip of second anterolateral tooth; central and southwestern Pacific .....

org/10.17600/100060); MUSORSTOM 10 (https://doi. org/10.17600/98100080). The specimens from the Papua New Guinea expeditions were collected by R.V. Alis during the BIOPAPUA (https://doi.org/10.17600/10100040) and PAPUA NIUGINI (https://doi.org/10.17600/18000841) ex- peditions. These deep-sea cruises, principal investigators S. Samadi, P. Bouchet, and L. Corbari, were operated by MNHN and the Institut de Recherche pour le Développement (IRD) as part of the Tropical Deep-Sea Benthos research program. The PAPUA NIUGINI expedition was conducted during the 
"Our Planet Reviewed". The expedition was organized by MNHN, Pro Natura International, IRD, and University of Papua New Guinea. The organizers acknowledge funding from the Total Foundation, Prince Albert II of Monaco Foundation, Fondation EDF, Stavros Niarchos Foundation. The expeditions operated under a permit delivered by the Papua New Guinea Department of Environment and Conservation.

We are very much indebted to Laure Corbari and Ling Ming Tsang (The Chinese University of Hong Kong) for generously sharing unpublished data on the molecular genetic relationships among the studied species. PC received generous support over the years from the Lee Kong Chian Natural History Museum, National University of Singapore. We are most grateful to Danièle Guinot and Masatsune Takeda for their many important suggestions which have helped improve the paper.

\section{REFERENCES}

ALCOCK A. 1898. - Materials for a carcinological fauna of India. No. 3. The Brachyura Cyclometopa. Part I. The family Xanthidae. Journal of the Asiatic Society of Bengal 67 (1): 67-233.

ALCOCK A. 1899. - An account of the deep-sea Brachyura collected by the Royal Indian Marine Survey Ship Investigator. Indian Museum, Calcutta (= Kolkata). https://www.biodiversitylibrary. org/page/ 10916535

AlCOCK A. 1900. - The Brachyura Catometopa or Grapsoidea. Materials for a carcinological fauna of India, no. 6. Journal of the Asiatic Society of Bengal 69: 279-456. https://www.biodiversitylibrary.org/page/35612227

ALCOCK A. \& ANDERSON A. R. S. 1895. - Illustrations of the zoology of the Royal Indian Marine Surveying Steamer Investigator, under the command of Commander A. Carpenter, R. N., D. S. O., of late Commander R. F. Hoskyn, R. N., and of Commander C. F. Oldham, R. N. Crustacea, Part 3. Office of the Superintendent of Government Printing, Calcutta (= Kolkata), pls 9-15. https:// www.biodiversitylibrary.org/page/38717082

AlCOCK A. \& ANDERSON A. R. S. 1899. - An account of the deepsea Crustacea dredged during the surveying season of 1897-98. Natural history notes from H.M. Royal Indian Marine Survey Ship 'Investigator,' Commander T. H. Heming, R.N., commanding. Annals and Magazine of Natural History Series 7, 3: 1-27, 278-292. https://doi.org/10.1080/00222939908678123

ANONYMOUS 1891. - Appendix No. XIII. Administration Report of the Indian Marine for the Official Year 1890-91. The Government Central Press, Bombay (= Mumbai).

ANONYMOUS 1914. - Biological Collection of the R.I.M.S. "Investigator". List of Stations. 1884-1913. Office of the Superintendent of Government Printing, Calcutta (= Kolkata).

CAstro P. 2007. - A reappraisal of the family Goneplacidae MacLeay, 1838 (Crustacea, Decapoda, Brachyura) and revision of the subfamily Goneplacinae, with the description of 10 new genera and 18 new species. Zoosystema 29 (4): 609-774.

Castro P. 2009. - Two new species of Carcinoplax H. Milne Edwards, 1852, and Pycnoplax Castro, 2007, from the western Pacific, and a description of the female of Thyraplax truncata Castro, 2007 (Crustacea, Decapoda, Brachyura, Goneplacidae). Zoosystema 31 (4): 949-957. https://doi.org/10.5252/z2009n4a9

CASTRO P. \& NG P. K. L. 2010. — Revision of the family Euryplacidae Stimpson, 1871 (Crustacea: Decapoda: Brachyura: Goneplacoidea). Zootaxa 2375: 1-130. https://doi.org/10.11646/zootaxa.2375.1.1

CHEN H. 1984. - A study of the genus Carcinoplax (Crustacea, Decapoda: Goneplacidae) of Chinese waters. Oceanologia et Limnologia Sinica 15: 188-201, pl. 1 (in Chinese with English abstract).
CHEN H. 1998. - The Goneplacidae (Crustacea: Brachyura) from Nansha Islands and adjacent waters, in Studies on Marine Fauna and Flora and Biogeography of the Nansha Islands and Neighbouring Waters 3. Academia Sinica, Beijing: 265-316 (in Chinese with English abstract).

Colosi G. 1923. - Una specie fossile di Gerionide (Decapodi brachiuri). Bolletino della Società dei Naturalisti in Napoli, Series 2, 15: 248-255.

Davie P. J. F., Guinot D. \& NG P. K. L. 2015. - Anatomy and functional morphology of Brachyura, in CASTRO P., DAVIE P. J. F., Guinot D., Schram F. R. \& Von Vaupel Klein J. C. (eds), Treatise on zoology - anatomy, taxonomy, biology, Decapoda: Brachyura, Brill, Leiden, The Netherlands. 9C-I: 11-163.

DOFLEIN F. 1904. - Brachyura. Wissenschaftliche Ergebnisse des Deutschen Tiefsee-Expedition auf dem Dempfer "Valdivia" 18981899, vol. 6: xiv + 314 p; Atlas: pls 1-58.

EsTAMPADOR E. P. 1937. — A check list of Philippine crustacean decapods. Philippine Journal of Science 62: 465-559.

ESTAMPADOR E. P. 1959. - A revised checklist of Philippine crustacean decapods. Natural and Applied Science Bulletin, Quezon City, 17: 1-127.

Froglia C. \& Clark P. F. 2011. - The forgotten Narrative of H.M.S. Challenger and the implications for decapod nomenclature. Zootaxa 2788: 45-56. https://doi.org/10.11646/zootaxa.2788.1.3

GUINOT D. 1969. - Recherches préliminaires sur les groupements naturels chez les Crustacés Décapodes Brachyoures, VII. Les Goneplacidae (suite). Bulletin du Muséum national d'Histoire naturelle, Série 2, 41: 507-528, pl. 2. https://www.biodiversitylibrary.org/page/55599183

Guinot D. 1989. - Le genre Carcinoplax H. Milne Edwards, 1852 (Crustacea, Brachyura: Goneplacidae), in FOREST J. (ed.), Résultats des campagnes MUSORSTOM volume 5. Muséum national d'Histoire naturelle, Paris, 385p. (Mémoires du Muséum national d'Histoire naturelle, Série A-Zoologie (1950-1992); 144): 265-345.

Ho P.-H., NG P. K. L., Chan T. Y. \& LeE D.-A. 2004. - New records of 31 species of brachyuran crabs from the joint TaiwanFrance expeditions, "Taiwan 2000" and "Taiwan 2001", off deep waters in Taiwan. Crustaceana 77: 641-668. https://doi. org/10.1163/1568540041958617

Hsuen P.-W. \& HuAnG J.-F. 2002. — Crabs of the family Goneplacidae (Decapoda, Brachyura) from Taiwan. Crustaceana 75: 111-136. https://doi.org/10.1163/15685400252902344

Huys R., Low M. E. Y., De Grave S., NG P. K. L. \& Clark P. F. 2014. - On two reports associated with James Wood-Mason and Alfred William Alcock published by the Indian Museum and the Indian Marine Survey between 1890 and 1891: implications for malacostracan nomenclature. Zootaxa 3757 (1): 1-78. https:// doi.org/10.11646/zootaxa.3757.1.1

IKeda H. 1998. - The Deep-Sea Crabs of Sagami Bay. Hayama Shiosai Museum, Kanagawa, Japan, 180 p.

Mendoza J. C. E., Naruse T., Tan S.-H., Chan T.-Y., Richer DE FORGES B. \& NG P. K. L. 2010. — Case studies on decapod crustaceans from the Philippines reveal deep, steep underwater slopes as prime habitats for 'rare' species. Biological Conservation 19: $575-586$

Miers E. J. 1885. - The Brachyura, in Tizard T. H., Moseley H. N., BuChananJ. Y. \& MuRRAY J. (eds), Narrative of the cruise of H.M.S. Challenger with a general account of the scientific results of the expedition. Report on the Scientific Results of the Voyage of H.M.S. Challenger during the years 1873-1876 under the command of Captain George S. Nares, R.N., F.R.S. and the late Captain Frank Tourle Thomson, R.N. prepared under the Superintendence of the late Sir C. Wyville Thomson, Knt., F.R.S. \& c. Regius Professor of Natural History in the University of Edinburgh Director of the civilian scientific staff on board and now of John Murray, one of the naturalists of the Expedition. Published by Order of Her Majesty's Government. London, Edinburgh and Dublin, Her Majesty Stationery Office. Narrative. 1 (2): 585-592. https://doi.org/10.5962/bhl.title.6513 
Miers E. J. 1886. - Part II. Report on the Brachyura collected by H.M.S. Challenger during the years 1873-76, in Report on the Scientific Results of the Voyage of H.M.S. Challenger during the years 1873-1876 under the command of Captain George S. Nares, N.R., F.R.S. and the late Captain Frank Tourle Thomson, R.N. prepared under the Superintendence of the late Sir C. Wyville Thomson, Knt., F.R.S. \&r. Regius Professor of Natural history in the University of Edinburgh of the civilian scientific staff on board and now of John Murray one of the naturalists of the Expedition. Zoology, Published by Order of Her Majesty's Government. London, Edinburgh and Dublin, HMSO. 17: i-1 + 1-362, pls 1-29. https://doi.org/10.5962/bhl.title.6513

MiLNE EDWARDS H. 1852. — Observations sur les affinités zoologiques et la classification naturelle des Crustacés. Annales des Sciences naturelles, Zoologie, Série 3, 18: 109-166, pls 3, 4. (second part in Annales des Sciences naturelles, Zoologie, Série 3, 20: 163-228, pls 6-11 [1853]).

MIYAKE S. 1991. - Brachyura (Crabs), in Japanese Crustacean Decapods and Stomatopods in Color, vol. 2. Hoikusha, Osaka (in Japanese; first edition in 1983, second printing in 1991).

NG P. K. L. 2000. - The deepwater swimming crabs of the genus Benthochascon Alcock and Anderson, 1899 (Crustacea: Decapoda: Brachyura: Portunidae), with description of a new genus for the American B. schmitti Rathbun, 1931. Journal of Crustacean Biology 20 (2): 310-324. https://doi.org/10.1163/1937240X-90000033

NG P. K. L. \& Kumar A. B. 2016. - Carcinoplax fasciata, a new species of deep-water goneplacid crab from southwestern India (Crustacea: Decapoda: Brachyura: Goneplacidea). Zootaxa 4147 (2): 192-200. http://doi.org/10.11646/zootaxa.4147.2.6

NG P. K. L. \& Mitra S. 2019. - Carcinoplax mistio, a new species of goneplacid crab from the Indian Ocean (Decapoda: Brachyura: Goneplacoidea). Nauplius 27: 1-15. https://doi. org/10.1590/2358-2936e2019004

NG P. K. L. \& TAN L. W. H. 1984. - The 'shell peeling' structure of the box crab Calappa philargius (L.) and other crabs in relation to mollusc shell architecture. Journal of the Singapore National Academy of Science 13: 195-199.

NG P. K. L. \& TAN L. W. H. 1985. - 'Right Handedness' in heterochelous calappoid and xanthoid crabs suggestion for a functional advantage. Crustaceana 49: 98-100. https://doi. org/10.1163/156854085X00288

NG P. K. L., Guinot D. \& Davie P. J. F. 2008. — Systema Brachyurorum: Part I. An annotated checklist of extant brachyuran crabs of the world. Raffles Bulletin of Zoology, Supplement 17: 1-286.

NG P. K. L., Mendoza J. C. E. \& Manuel-Santos M. 2009. Tangle net fishing, an indigenous method used in Balicasag Island, central Philippines. Raffles Bulletin of Zoology Supplement 20: 39-46.

Ng P. K. L., Priyaja P., Kumar A. B. \& Suvarna Devi S. 2019. On a collection of crabs (Crustacea, Brachyura) from the southwestern coast of India, with a discussion of the systematic position of Nectopanope Wood-Mason in Wood-Mason \& Alcock, 1891 (Euryplacidae). Zookeys 818: 1-24. https://doi.org/10.3897/ zookeys. 818.32108

RATHBUN M. J. 1914. - A new genus and some new species of crabs of the family Goneplacidae. Scientific Results of the Philippine cruise of the Fisheries Streamer "Albatross," 1907-1910 — No.
32. Proceedings of the United States National Museum 48 (2067) 137-154. https://doi.org/10.5479/si.00963801.2067.137

SAKAI T. 1969. - Two new genera and twenty-two new species of crabs from Japan. Proceedings of the Biological Society of Washington 82: 243-280. https://www.biodiversitylibrary.org/page/34595262 SAKAI T. 1976. - Crabs of Japan and the Adjacent Seas. In three volumes: English text, Japanese text,, Plates. Kodansha Ltd., Tokyo.

Selvaraj G. S. D. \& Kathirvel M. 1980. - Carcinoplax verdensis (Decapoda: Brachyura: Goneplacidae) a new record from Indian waters. Journal of Marine Biological Association of India 22: 159-161.

SERÈNE R. 1968. - The Brachyura of the Indo-West Pacific region, in Prodromus for a check list of the non-planctonic marine fauna of South East Asia, UNESCO, Singapore National Academy of Science, Special Publication 1, Fauna III Cc3: 33-118.

SERÈne R. \& LoHAVAniJAYA P. 1973. - The Brachyura (Crustacea: Decapoda) collected by the Naga Expedition, including a review of the Homolidae, in Brinton E., NEWMAN W. A. \& WoOster W. S. (eds), Scientific Results of Marine Investigations of the South China Sea and the Gulf of Thailand, 1959-1961. Naga Report4 (4): 1-187.

SerÈne R. \& VAdOn C. 1981. — Crustacés Décapodes : Brachyoures. Liste préliminaire, description de formes nouvelles et remarques taxonomiques, in Résultats des Campagnes MUSORSTOM. I. Philippines (18-28 mars 1976), vol. 1. Mémoires ORSTOM (Paris) 91: 117-140. SPiridonov V. A., Neretina T. V. \& SChepetov D. 2014. - Morphological characterization and molecular phylogeny of Portunoidea Rafinesque, 1815 (Crustacea Brachyura): Implications for understanding evolution of swimming capacity and revision of the family-level classification. Zoologischer Anzeiger 253: 404429. https://doi.org/10.1016/j.jcz.2014.03.003

STIMPSON W. 1871. - Brachyura. Preliminary report on the Crustacea dredged in the Gulf Stream in the Straits of Florida, by L. F. Pourtales, Assist. U.S. Coast Surveys, Part 1. Bulletin of the Museum of Comparative Zoology at Harvard College 2: 109-160. https://www.biodiversitylibrary.org/page/6313618

TAKedA M. \& YaganisaWA F. 1985. - Rediscovery of two Carcinoplax crabs in the Kumanonada Sea, east of Kii Peninsula, Central Japan, with notes on distribution of the related species. Bulletin of the Biogeographical Society of Japan 40 (8): 57-62.

TaKeda M., Komai T., Komatsu H. \& IKeda H. 2006. — Crab fauna of the Sagami Sea, Pacific coast of central Japan, in Study on environmental changes in the Sagami Sea and adjacent coastal area with time serial comparison of fauna and flora II. Marine organisms (Animals (Arthropods-Chordates)). Memoirs of the National Science Museum (Tokyo) 41: 183-215 (in Japanese).

Tesch J. J. 1918. - Goneplacidae and Pinnotheridae. The Decapoda Brachyura of the Siboga Expedition, 2. Siboga-Expeditie 39(c1), livr. 84: 149-295, pls 7-18.

Whitelegge T. 1900. - Crustacea. Part 1. Scientific results of the trawling expedition of H.M.C.S. 'Thetis' off the coast of New South Wales in February and March, 1898. Memoirs of the Australian Museum 4: 135-199, pls 32-35. https://doi.org/10.3 853/j.0067-1967.4.1900.427

WOOD-MASON J. \& ALCOCK A. 1891. - Note on the results of the last season's deep-sea dredging. Natural history notes from $\mathrm{H}$. M. Indian Marine Survey Steamer 'Investigator,' no. 21. Annals and Magazine of Natural History, Series 6, 7: 258-272. https:// www.biodiversitylibrary.org/page/19243194 